Review

\title{
From Residues to Added-Value Bacterial Biopolymers as Nanomaterials for Biomedical Applications
}

\author{
Francisco G. Blanco ${ }^{1,2} \mathbb{C}^{-}$, Natalia Hernández ${ }^{1,2,+} \oplus$, Virginia Rivero-Buceta ${ }^{1,2,+} \oplus$, Beatriz Maestro ${ }^{3}$, \\ Jesús M. Sanz ${ }^{3}\left(\mathbb{D}\right.$, Aránzazu Mato ${ }^{1,2}$, Ana M. Hernández-Arriaga ${ }^{1,2}$ and M. Auxiliadora Prieto ${ }^{1,2, * \mathbb{C}}$ \\ 1 Interdisciplinary Platform for Sustainable Plastics towards a Circular Economy-Spanish National Research \\ Council (SusPlast-CSIC), 28040 Madrid, Spain; francisco.blanco@cib.csic.es (F.G.B.); \\ nhernandezh@cib.csic.es (N.H.); mvrivero@cib.csic.es (V.R.-B.); aranzazu.mato@gmail.com (A.M.); \\ arriaga@cib.csic.es (A.M.H.-A.) \\ 2 Polymer Biotechnology Group, Microbial and Plant Biotechnology Department, Biological Research Centre \\ Margarita Salas, CIB-CSIC, 28040 Madrid, Spain \\ 3 Host-Parasite Interplay in Pneumococcal Infection Group, Microbial and Plant Biotechnology Department, \\ Biological Research Centre Margarita Salas, CIB-CSIC, 28040 Madrid, Spain; \\ beatriz.maestro@cib.csic.es (B.M.); jmsanz@cib.csic.es (J.M.S.) \\ * Correspondence: auxi@cib.csic.es \\ + These authors contributed equally to the work.
}

check for updates

Citation: Blanco, F.G.; Hernández, N.; Rivero-Buceta, V.; Maestro, B.; Sanz, J.M.; Mato, A.; HernándezArriaga, A.M.; Prieto, M.A. From Residues to Added-Value Bacterial Biopolymers as Nanomaterials for Biomedical Applications.

Nanomaterials 2021, 11, 1492. https:// doi.org/10.3390/nano11061492

Academic Editor: Orietta Monticelli

Received: 28 April 2021

Accepted: 26 May 2021

Published: 4 June 2021

Publisher's Note: MDPI stays neutral with regard to jurisdictional claims in published maps and institutional affiliations.

Copyright: (c) 2021 by the authors. Licensee MDPI, Basel, Switzerland. This article is an open access article distributed under the terms and conditions of the Creative Commons Attribution (CC BY) license (https:/ / creativecommons.org/licenses/by/ $4.0 /)$.

\begin{abstract}
Bacterial biopolymers are naturally occurring materials comprising a wide range of molecules with diverse chemical structures that can be produced from renewable sources following the principles of the circular economy. Over the last decades, they have gained substantial interest in the biomedical field as drug nanocarriers, implantable material coatings, and tissue-regeneration scaffolds or membranes due to their inherent biocompatibility, biodegradability into nonhazardous disintegration products, and their mechanical properties, which are similar to those of human tissues. The present review focuses upon three technologically advanced bacterial biopolymers, namely, bacterial cellulose (BC), polyhydroxyalkanoates (PHA), and $\gamma$-polyglutamic acid (PGA), as models of different carbon-backbone structures (polysaccharides, polyesters, and polyamides) produced by bacteria that are suitable for biomedical applications in nanoscale systems. This selection models evidence of the wide versatility of microorganisms to generate biopolymers by diverse metabolic strategies. We highlight the suitability for applied sustainable bioprocesses for the production of BC, PHA, and PGA based on renewable carbon sources and the singularity of each process driven by bacterial machinery. The inherent properties of each polymer can be fine-tuned by means of chemical and biotechnological approaches, such as metabolic engineering and peptide functionalization, to further expand their structural diversity and their applicability as nanomaterials in biomedicine.
\end{abstract}

Keywords: bacterial polymers; bacterial cellulose; polyhydroxyalkanoates; $\gamma$-polyglutamic acid; upcycled polymers; biomedical applications; biopolymer functionalization

\section{Introduction}

Ongoing global population growth and aging imply an increase in global demand for sustainable development, which involves the rational use of resources and the maintenance of ecosystem services [1]. This calls for more efficient production methods in order to render industrial and technological development compatible with social wellbeing and environmental protection. Consequently, there is a need for environmentally friendly and low-impact methodologies in manufacturing processes, aimed at reducing byproducts whilst upcycling waste [2]. In this sense, increasing pressure on the environment due to the widespread consumption of petroleum-based polymers has hastened the development of biodegradable and environmentally friendly materials such as bio-based polymers. Biopolymers are naturally occurring materials comprising a wide range of molecules with diverse chemical structures that can be produced in a sustainable manner from renewable 
sources, in compliance with the United Nations Sustainable Development Goals and the concept of the circular economy.

Biopolymers are widely applied for biomedical purposes since they are generally biocompatible and biodegradable into nontoxic products; moreover, they present low antigenicity and high bioactivity, they can be processed into complicated shapes, they are capable of supporting cell growth and proliferation, and they exhibit highly diverse thermal and mechanical properties [3]. These inherent properties can be fine-tuned by means of biotechnological and chemical approaches. Current strategies based on cutting-edge technologies, such as synthetic and systems biology combined with advanced materials technology, provide pathways for enhancing the structural and functional complexity of these biopolymers, thereby expanding the catalog of available biomaterials beyond that which exists in nature and extending their potential applications in the biomedical sector (e.g., drug delivery, tissue engineering) [3]. The bottom-up strategy of material design opens up important opportunities for the creation of specific cutting-edge biomedical applications [4].

In particular, bacterial polymers have attracted much attention over the last decade due to their sustainable production and the fact that their properties can be altered with the use of bioengineering tools. In the context of the circular economy, bacteria are able to grow and produce materials of interest from complex carbon sources such as industrial and municipal wastes. It entails developing bioprocesses in order to upcycle the abovementioned waste into added-value materials with application in numerous industrial sectors. Indeed, bacteria produce a broad range of polymers as part of their inherent physiology, and many of these are currently being used as materials for biomedical applications [5]. Some examples are polysaccharides, including alginates, hyaluronic acid, and bacterial cellulose (BC); polyesters, comprising the family of polyhydroxyalkanoates (PHAs); polyamides, which are amino acid polymers synthesized in a ribosome-independent manner, such as cyanophycins, $\gamma$-polyglutamic acid (PGA), or poly- $\varepsilon$-lysine; and, finally, polyanhydric polymers, such as polyphosphates, that are produced by a wide variety of bacteria for use as energy storage polymers [5].

Bacterial polymers have grown exponentially in biomedical research, mainly in three domains: drug nanocarriers, implantable material coatings, and tissue-regeneration scaffolds or membranes. Different types of nanocarriers loaded with a particular drug (namely, nanospheres, nanocapsules, polymeric micelles) are employed for drug delivery because they enhance the pharmacokinetic and pharmacodynamic profile of the drugs by increasing the bioavailability of bioactive molecules that present poor solubility in water, promoting sustained release and enhancing permeability across biological barriers. Furthermore, they can reduce side effects by enabling targeted and controlled drug release [6]. However, these nanocarriers interact massively with their environment, e.g., biological fluids and cells, where they are rapidly removed by the mononuclear phagocyte system. In order to prolong their half-life, surface modification by means of coating with biopolymers (or direct formulations of biopolymer nanocarriers) has largely proven to confer stealth properties to the resulting nanosystems [7], which help to evade the immune system, thus prolonging their therapeutic effects. Bacterial polymers are particularly interesting for nanocarrier formulations due to their intrinsic biocompatibility and biodegradability properties, which enable the release of the encapsulated compound associated with the degradation of the polymeric matrix into nontoxic monomers.

Another area of interest in relation to biopolymers involves surface coatings of temporary or permanent implantable medical devices. The main issue associated with implant failure continues to be associated with bacterial adhesion and subsequent biofilm formation on the device surface. Different strategies have been employed to prevent colonization by bacteria, such as the design of nanostructured antibacterial topologies [8], surface coating of the implant with intrinsic antimicrobial polymers [9], chemical modification of surface materials to prevent adhesion or to provide antibacterial activity [10], and the immobilization of antimicrobial peptides, enzymes, or inorganic compounds [11]. Due to the 
emergence of antibiotic-resistant bacteria, the use of functional nanomaterials to control device-associated infections has been proposed as a promising alternative to conventional antibiotic treatment [12].

Finally, bacterial polymers present a series of advantages in the fields of tissue regeneration and wound healing. When formulated as hydrogels, membranes, or 3D scaffolds, due their highly swollen three-dimensional environment, bacterial polymers can simulate an extracellular cell matrix (ECM) structure, providing the damaged tissue with a friendly environment for regeneration [13]. Furthermore, many strategies have been reported to functionalize these materials with cell-attachment motives, antimicrobial functionalities, or specific cell type effectors (i.e., growth factors, cytokines) with the aim of enhancing and accelerating tissue regeneration and wound closure [13].

The present paper focuses on three bacterial biopolymers (one of each carbon backbone structure) suitable for biomedical applications in nanoscale systems. In particular, we focused upon the three most technologically advanced ones (PHA, BC, and PGA). Herein, they are considered to constitute models of each carbon-backbone structure (polysaccharides, polyesters, and polyamides) (Figure 1 and Table 1). We will emphasize their suitability for applied sustainable bioprocesses based on renewable carbon sources, their modification to further expand their structural diversity, and their applicability for biomedical purposes.

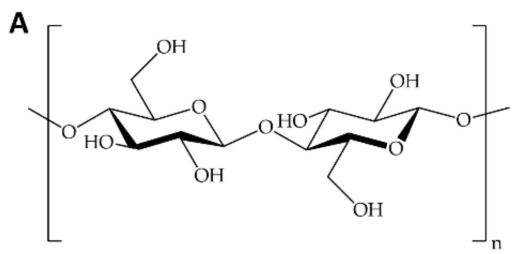

B
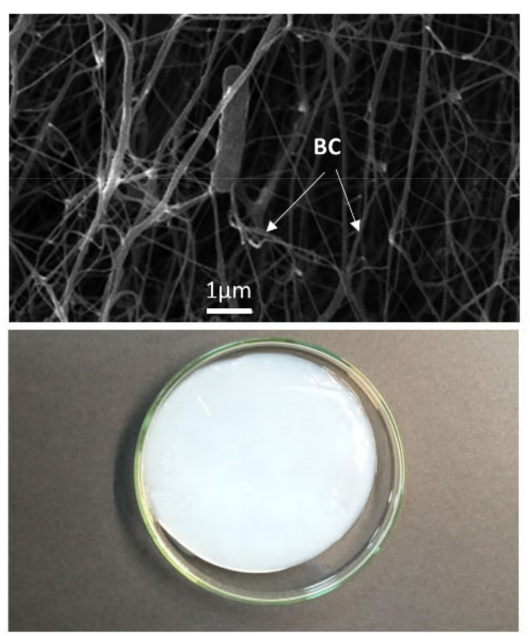
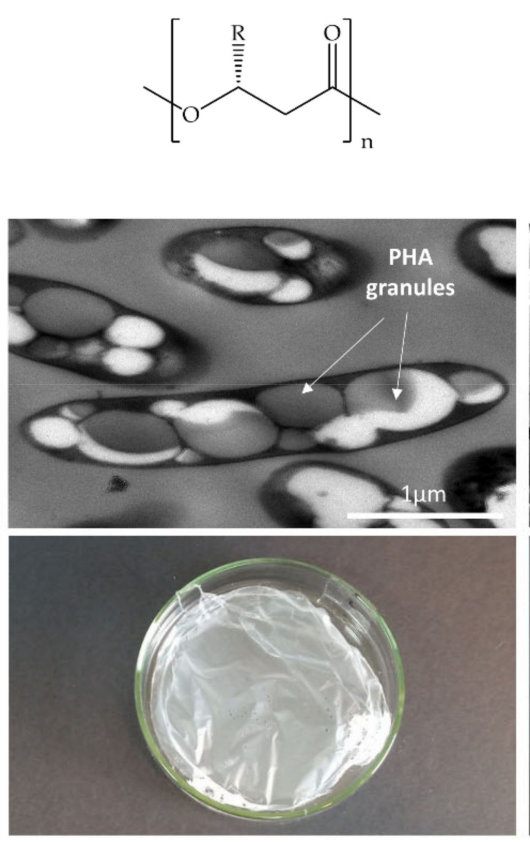

C<smiles>CN[C@@H](CCC(C)(C)C)C(=O)O</smiles>
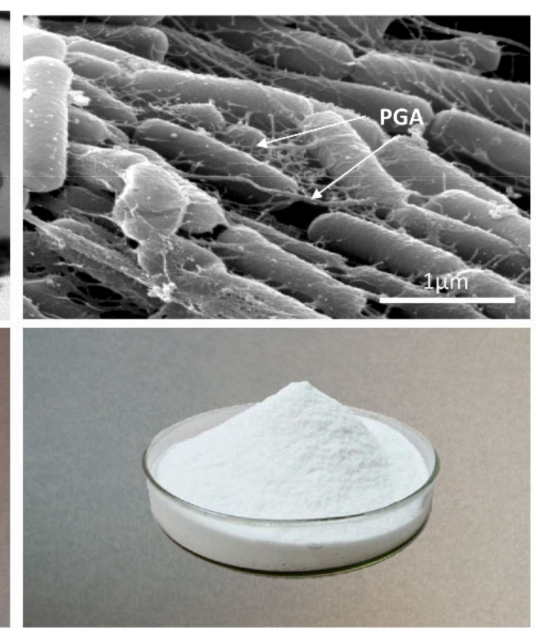

Figure 1. Chemical, microscopic, and macroscopic structure of BC, PHA, and PGA produced by model bacteria Komagataeibacter medellinensis, Pseudomonas putida, and Bacillus subtilis. Upper panels represent the chemical polymer structure, middle panels show electron microscopy images of the microorganisms producing the polymer, and lower panels show the macroscopic appearance of the purified polymer of BC (A), PHA (B), or PGA (C). SEM images of K. medellinensis and B. subtilis. Reprinted with permission from [14,15]; Copyright Microbiology Society, 2013, 2006. 
Table 1. Main characteristics of the model bacterial polymers BC, PHA, and PGA.

High diversity. Polymer properties rely on its Anionic. D- or L-glutamic acid (glu)

monomer combination homopolymers, or D-/L-glu copolymers

Hydrophilic

Scl-PHA Cupriavidus necator, Bacillus spp., B. subtilis

BC

Polysaccharide (Figure 1A)

Chemical structure

Glucose (glc) homopolymer. Properties of the

polymer depend on culture conditions

Hydrophilic

Industrial production prototype bacteria

Species belonging to Komagataeibacter genus, K. xylinus

Direct: sugars, preference depends on the

species

Indirect: ethanol, converted into acetate, and

finally, glc through tricarbolxylic acid cycle

(TCA) and gluconeogenesis (GNG) (Figure 2)

Submerged fermentation

Culture conditions for pure cultures industrial production

Mainly in static conditions for biomedical applications

Extracellular polymer. Easy, cheap

purification, isolation, and alkali treatment

Downstream processing
PHA

Polyester (Figure 1B)

Hydrophobic

High diversity

Halomonas spp.

Mcl-PHA Pseudomonas spp.
Direct: fatty acids

Indirect: sugars through TCA and de novo

synthesis of fatty acids (Figure 3)

Submerged fermentation

Batch and Fed-Batch strategies

Intracellular polymers. Costly purification

cell lysis, release, and polymer isolation

\section{PGA}

Direct: glutamic acid

Indirect: sugars, through TCA and alpha-ketoglutarate $(\alpha-K G)$ conversion into glutamic acid (Figure 4 )

Submerged and solid-state fermentation

Extracellular polymer. Precipitation by chelation, solubility reduction or filtration 


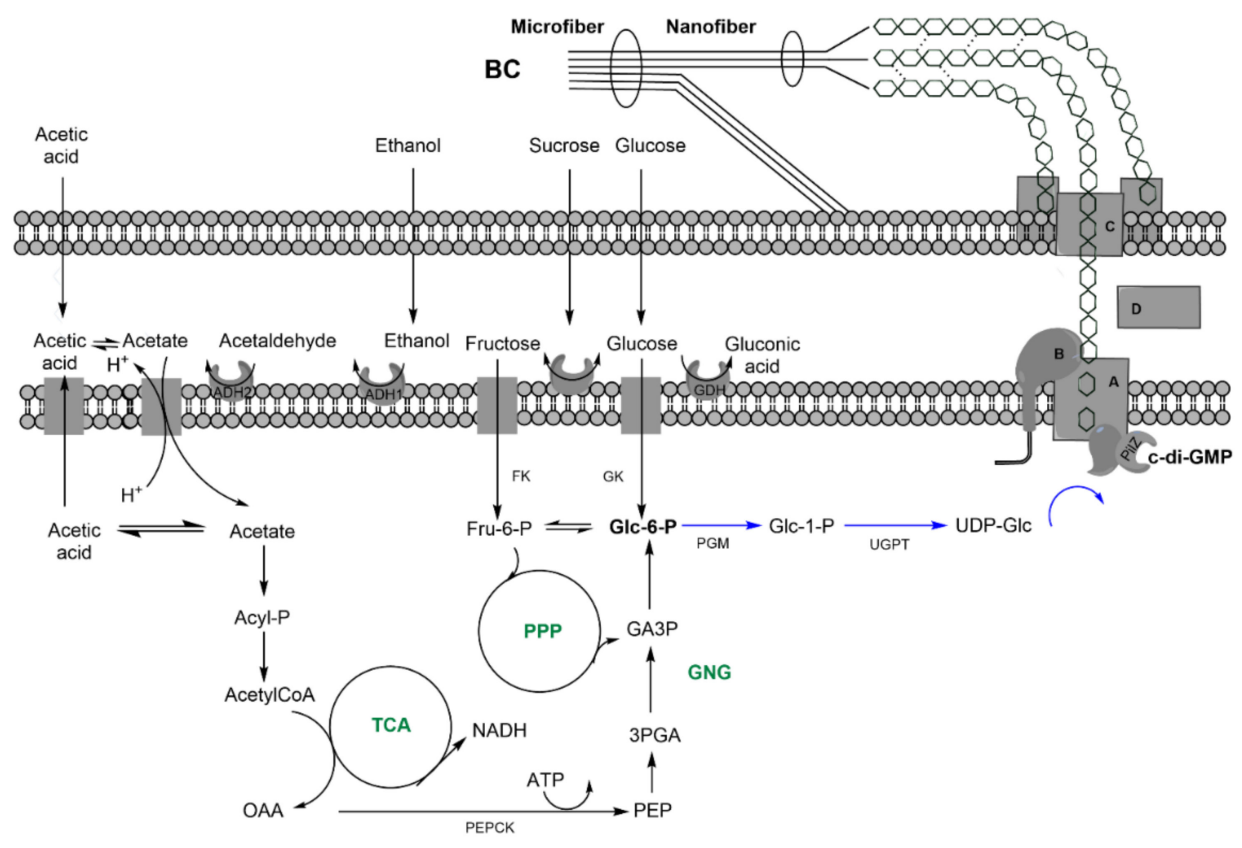

Figure 2. Metabolic network of BC in Komagataeibacter xilynus E25. Sugars are metabolized through the pentoses phosphate pathway (PPP) to Glc-6-P, while glycolysis is not a relevant pathway in Komagataeibacter species due to the lack of phosphofructokinase. Glucose is partially oxidized in the periplasm to obtain reductor power. In the case of K. xylinus E25, the oxidation product is gluconic acid, although the final product is species-dependent. Ethanol is dehydrogenized to acetate by ADH1, an $\mathrm{ADH} 2$ inner-membrane-bound enzyme, and directed to Glc-6-P by the tricarboxylic acid cycle (TCA) and gluconeogenesis (GNG) pathways. Glc-6-P is isomerized to Glc-1-P by phosphoglucomutase (PGM) and is subsequently transformed to UDP-Glc by UTP-Glc-1-P uridylyltransferase (UGPT). Upon activation by c-di-GMP of BcsA, UDP-Glc units are polymerized into nascent glucan chains coupled with its translocation to the periplasm by means of cellulose synthase subunits BcsA (A) and $\mathrm{BcsB}(\mathrm{B}) . \mathrm{BcsC}(\mathrm{C})$ is then involved in the arrangement of the nascent chains, and $\mathrm{BcsD}$ (D) forms the pore to export the nanofibrils. The main metabolic pathways, TCA, GNG, and PPP, are indicated in green. The pathway leading to BC synthesis is indicated in blue. Key enzymes, phosphoglucoisomerase (PGI), phosphoenol pyruvate carboxykinase (PEPCK), PGM, and UGPT are indicated. OAA: oxalacetate; PEP: phosphoenol pyruvate; 3PGA: 3-phosphoglycerate; GA3P: glyceraldehyde-3-P. 


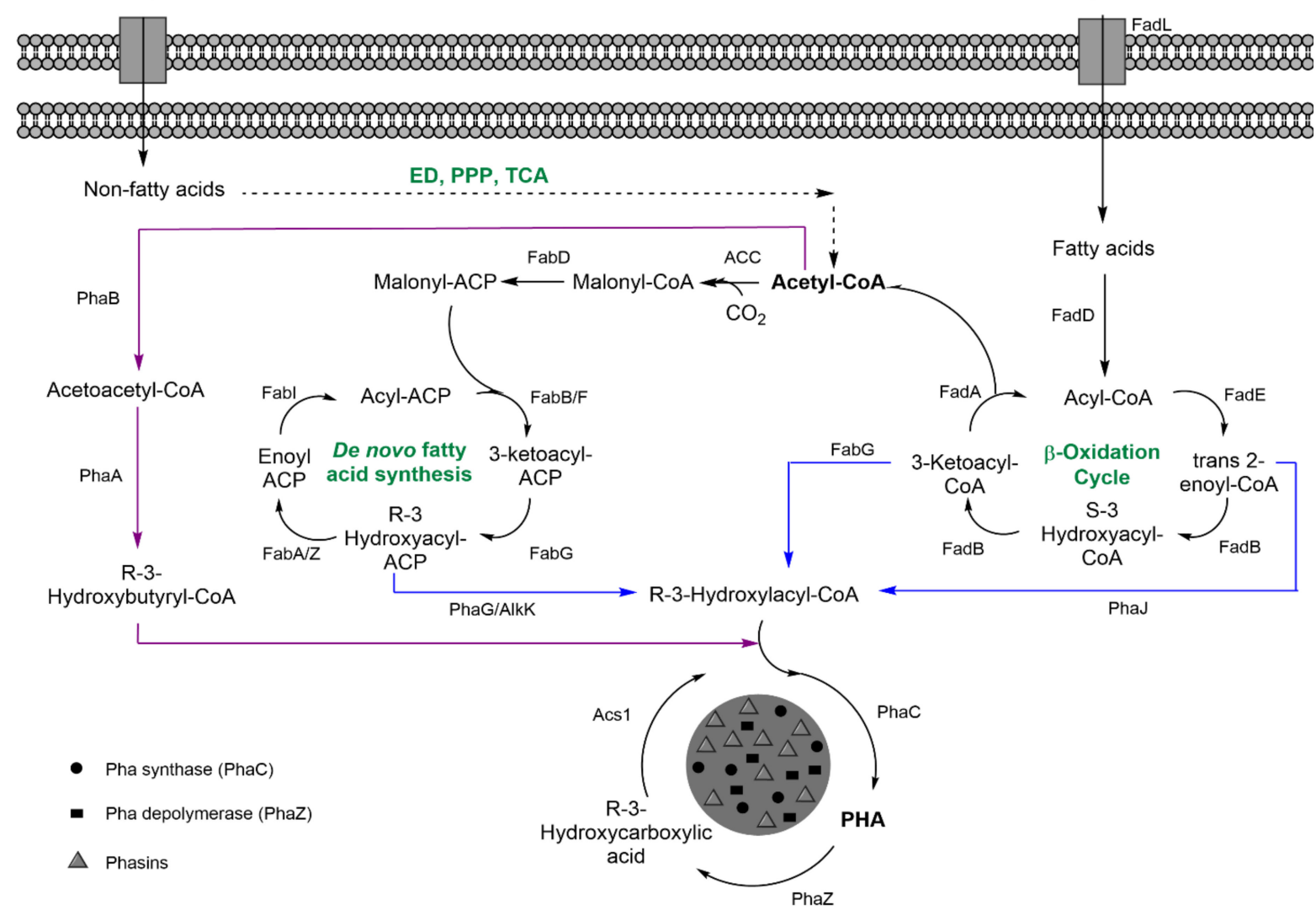

Figure 3. Metabolic network of PHA metabolism in model bacteria C. necator H16 (scl-PHA) and P. putida KT2440 (mcl-PHA). Fatty acids are metabolized via the $\beta$-oxidation cycle into acetyl-CoA, while nonfatty acid substrates are metabolized via the Entner-Doudoroff (ED) pathway, TCA and PPP, into acetyl-CoA. In PHB metabolism, two acetyl-CoA molecules condensate into acetoacetyl-CoA by PhaB and are then converted into R-3-hydroxybutyryl-CoA (PHB monomer) by PhaA. In PHA metabolism, fatty acids are metabolized in the $\beta$-oxidation cycle, where the intermediates 3-ketoacyl-CoA and trans-2-enoylCoA can be directly converted into PHA monomers (R-3-HA-CoA) by FabG and PhaJ, respectively. Alternatively, through de novo fatty acid synthesis, acetyl-CoA can be converted from R-3-hydroxyl-ACP to R-3-HA-CoA by two enzymatic steps catalyzed by PhaG and AlkK. PHA and PHB are synthetized in a continuous cycle that drives carbon and energy flux, in which the monomers are polymerized by PhaC, depolymerized into the respective R-3-hydroxycarboxylic acids by PhaZ, and reconverted into the activated monomer R-3-HA-CoA by Acs1. The carbon central metabolic pathways are indicated in green, the pathway leading to PHB synthesis is in purple, and the one leading to PHA synthesis is shown in blue. Key enzymes are indicated. 


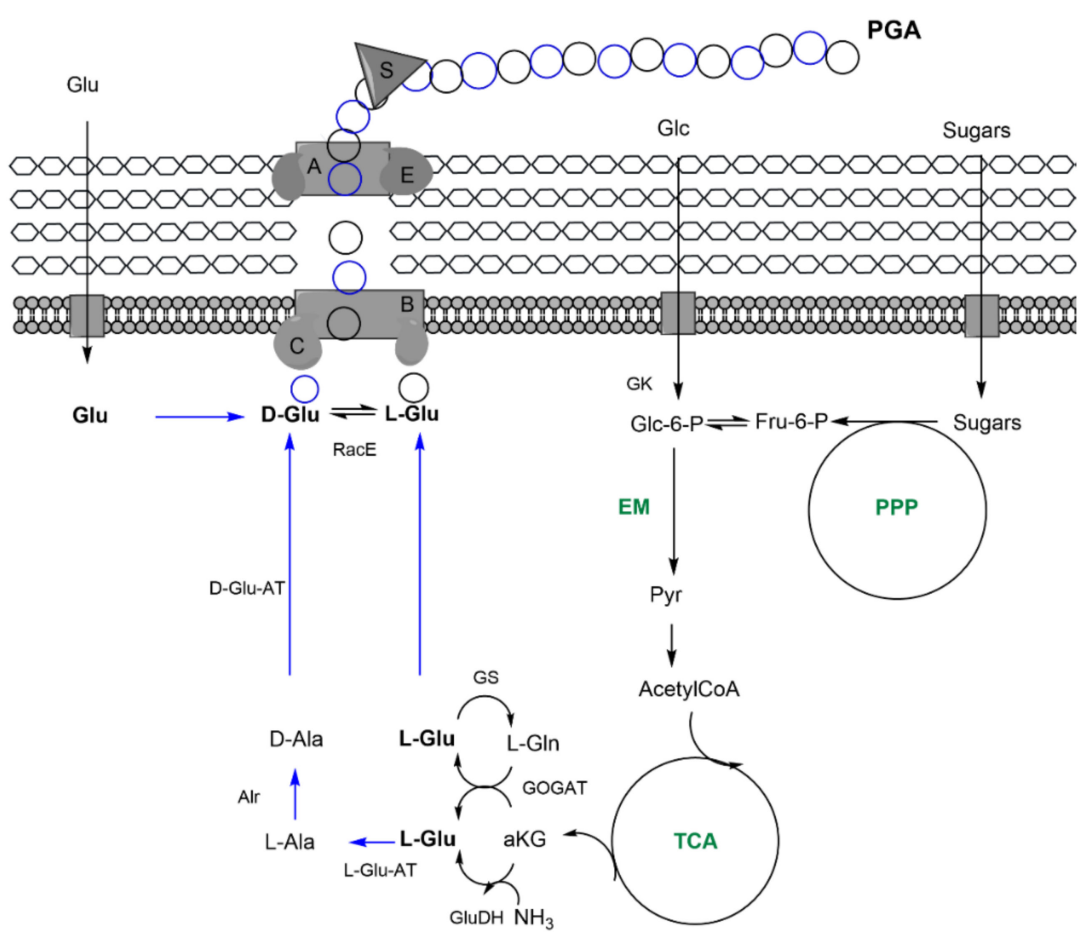

Figure 4. Metabolic network of PGA metabolism in model bacteria B. subtilis 168. Exogenous glu can serve as a direct precursor of PGA synthesis. Alternatively, sugars are metabolized via the Embden Meyerhof (EM) pathway, PPP and TCA. $\alpha$ KG from TCA is then converted to L-glu (the PGA monomer) by two different enzymes-glutamine oxoglutarate aminotransferase (GOGAT), which transfers the amino group from a glutamine molecule, and Glu dehydrogenase (GluDH), which incorporates the amino group from an ammonium molecule. In the species producing L/D-PGA (such as B. subtilis), a racemization reaction to produce the $\mathrm{D}$-isomer takes place. This can be produced by means of two different enzymatic reactions: the Glu racemase (RacE) directly interconverting the isomers and a 3-enzymatic-step reaction by L-glu-pyruvate aminotrasnferase (L-Glu-AT), alanine racemase (Alr), and D-glu-pyruvate aminotransferase (D-Glu-AT). D/L glu monomers are then polymerized in the active site formed by membrane-bound PgsB (B) and PgsC (C), and the elongated chain is then removed from the active site by PgsA (A). The role of PgsE (E) is still under debate, while PgdS (S) is a secreted peptidase that releases the PGA to the medium. The main metabolic pathways, TCA, GNG, and PPP, are indicated in green. The pathway leading to PGA synthesis is indicated in blue. Key enzymes, glucokinase (GK), GOGAT, GluDH, glutamine synthetase (GS), L-Glu-AT, Alr, D-Glu-AT, and RacE are indicated.

\section{BC, PHAs, and PGA as Model Bacterial Biopolymers Produced by Upcycling Bioprocesses}

Bacteria exhibit wide-ranging metabolic versatility, which is also reflected by the great variety of polymers they are able to naturally synthesize. Polymeric matrices are involved in diverse cell functions, such as promoters of bacterial adhesion, energy and carbon storage, pathogenicity factors, or biofilm constituents [5].

\subsection{Molecular Basis of the Biopolymer Synthesis}

$\mathrm{BC}$ is a linear, extracellular polysaccharide composed of chains of $\beta(1,4)$ O-glycosidicbounded glucose (glc) units (Figure 1A). These chains aggregate upon extrusion into nanofibers to further form a 3D-structured microfiber network (Figure 2).

It is produced by bacteria of the genera Acetobacter, Agrobacterium, Azotobater, Pseudomonas, Rhizobium, Escherichia, Salmonella, or Komagataeibacter [16]. However, the species of the Komagataeibacter genus are the most effective nanocrystalline BC producers. $K$. xylinus is the model organism that is most industrially exploited. This bacterium has un- 
dergone various phylogenetic reclassifications over the years, originally named Acetobacter xylinum, subsequently Gluconacetobacter xylinum, and finally renamed as Komagataeibacter xylinus [17]. To avoid any misunderstanding, our paper will refer to these strains as they were named in the original article. The proposed polymer function varies from one species to another; for example, these functions can involve protection against ultraviolet radiation and moisture retention, retaining the bacteria in an aerobic environment, or enhancing surface colonization [18].

$\mathrm{BC}$ is produced by the polymerization of units of 1-uridine diphosphate glucose (1UDP-glc) (Figure 2). Glucose is first phosphorylated to glucose-6P, isomerizated to glc-1P, and finally converted into 1-UDP-glc [19]. The monomeric unit, UDP-glc, is polymerized and translocated by cellulose synthases $\mathrm{B} \operatorname{cs} \mathrm{A}$ and $\mathrm{B} \operatorname{csB}$ (or the fused version, $\mathrm{Bcs} \mathrm{AB}$ ) in a process regulated by BcsA allosteric activator cyclic di-guanosine monophosphate (c-diGMP) [20]. BcsC constitutes an outer membrane translocase, while periplasmic nonessential $\mathrm{BcsD}$ is involved in the fibrils' hierarchical arrangement [18]. These four genes, $b \operatorname{cs} A B C D$, form the cellulose synthase operon. Depending on the operon type and species, accessory genes modulating BC synthesis may be present, such as $b c s Z$ (endo- $\beta$-1,4-glucanase), $\operatorname{cc} p A x$, or $\operatorname{bgl} l A x$ ( $\beta$-glucosidase) [18,21].

The preference for one carbon source or another is strain-dependent [22] as a result of the genome flexibility of the genus [23]. Disaccharides, such as sucrose, are hydrolyzed in the periplasm, and the monomers are actively translocated in phosphorylation [24]. Glucose-6P can either be converted into the BC precursor, 1-UDP-glc, or further catabolized by central carbon pathways. Most of the Komagataeibacter genus lack or present very low phosphofructokinase activity; hence, the Emden-Meryorf-Parnas pathway is not present in K. xylinus. Subsequently, glucose is metabolized by partial oxidation to gluconate-6P or by decarboxylation into ribulose-5P, entering the pentoses phosphate pathway (PPP). Another BC precursor is ethanol, which can be dehydrogenated into acetate by the membrane-bound alcohol and aldehyde dehydrogenases (ADH1 and ADH) (Figure 2) and is incorporated as acetate into the cell. Further phosphorylation results in acetyl-CoA, which feeds a glyoxylate-shunted tricarboxylic acid (TCA) cycle, from which oxalacetate can be decarboxylated to render phosphoenol pyruvate, the starting point of gluconeogenesis (GNG), which, in turn, feeds the glc-6P pool $[25,26]$. Furthermore, ethanol has been reported as a BC production stimulant via upregulation of UDP-glc- and bcs-related genes. Moreover, it downregulates those of the IS110 transposase family (involved in the appearance of celluloseless phenotypes) and synthesis genes associated with byproducts [27]. These byproducts, mainly water-soluble exopolysaccharides (EPSs) such as acetan, are strain-dependent, and the effect of their synthesis upon BC yield remains unclear. Other BC carbohydrate precursors such as galactose or xylose have been described in the literature (see below).

PHAs are linear, intracellular polyesters of R-3-hydroxyalkanoate units (Figure 1B) that accumulate in the cytoplasm as hydrophobic inclusions or granules (100-500 nm) coated with a series of granule-associated proteins (GAPs) involved in PHA metabolism and granule formation (Figure 3). These proteins include polymer synthases, depolymerases, and phasins, the latter constituting the major fraction of GAPs that isolate the hydrophobic PHA granule from the hydrophilic cytoplasm and ensure granule number and size, in addition to other physiologic functions [28]. PHAs are produced upon nutrient imbalance as a carbon and energy storage, and the PHA cycle regulates carbon flow in the cell [29]. To date, over 90 genera, including photoautotrophs and chemotrophs, Gram-positive and Gram-negative genera, are known to produce PHA under both aerobic and anaerobic conditions [30]. Furthermore, several recombinant strains have been developed to produce PHA. Despite the fact that the most common substituent groups found in PHA monomers are aliphatic chains, over 150 different monomer constituents have been described [31]. They are often classified as short-chain-length PHA (scl-PHA) or medium-chain-length PHA (mcl-PHA) based on monomer size, with 3-5 or 6-14 carbon units, respectively. The type of PHA synthesized depends upon the type of PHA synthase (PhaC), which can 
accept precursors of a certain carbon length, as well as the substrate employed and the metabolic and regulatory networks in each species [31].

Figure 3 summarizes the PHA metabolism for two model scl- and mcl-PHA producers, C. necator and P. putida, respectively. Scl-PHAs, namely, polyhydroxybutyrate $(\mathrm{P}(3 \mathrm{HB}))$, are synthesized by condensation of two molecules of acetyl-CoA to acetoacetyl-CoA by PhaA, a $\beta$-ketothiolase, and reduced to 3-hydroxybutyryl-CoA, the PHB monomer, by acetoacetyl-CoA reductase PhaB. The monomers are then polymerized by PhaC synthase. Mcl-PHA structures are more diverse since they are mainly produced as heteropolymers of R-3-hydroxyacyl-CoA (R-3-HA-CoA) monomers of different lengths. Monomers are provided as intermediates of fatty acid metabolism via the $\beta$-oxidation pathway and de novo fatty acid synthesis. $\beta$-oxidation degrades fatty acids and provides trans- $\Delta 2$-enoylCoA, S-3-hydroxyacyl-CoA, and 3-ketoacyl-CoA metabolites that can be converted into R-3-HA-CoA by enoyl-CoA hydratase PhaJ, 3-HA-CoA dehydratase/epimerase FadB, and 3-ketoacyl-CoA reductase FabG, respectively. De novo fatty acid synthesis incorporates indirect precursors such as carbohydrates through their complete oxidation to acetyl-CoA and conversion via the TCA cycle into malonyl-CoA $[29,30]$. The latter CoA group is replaced by an acyl carrier protein (ACP), and the malonyl-ACP is further elongated by the addition of successive acetyl-CoA units. The resulting R-3-hydroxyacyl-ACP intermediates can be converted to R-3-HA-CoA monomers by PhaG thioesterase and the fatty acid CoA ligase (alk1), thus producing the substrates of PhaC [32]. PHA metabolism is involved in a continuous cycle of synthesis (PhaC) and degradation (PhaZ), determining PHA turnover in which the monomers can be metabolized via $\beta$-oxidation or reincorporated into the granule [33].

PGA is a linear, water-soluble, extracellular polyamide consisting of $L, D$, or both enantiomers of glutamic acid (glu). The units are linked by an amide bond between the amino and $\gamma$-carboxy groups of the glu residues (Figure 1C). The physiological function of PGA has not yet been completely elucidated, although it is believed to depend on the microorganism environment and whether it is bound to peptidoglycan [34]. Phylogenetically, two PGA producer groups can be distinguished: non-Bacillus (i.e., Planococcus halophilus or $S$. epidermidis) and Bacillus species. Some of the bacillary species can synthesize PGA attached to the peptidoglycan layer (i.e., B. anthracis), whereas others release it into the medium. The latter group, which includes B. subtilis, B. licheniformis, and B. amyloliquefaciens, together with glu-independent producers (that produce glu monomers through de novo synthesis), is the principal species exploited for the industrial production of PGA [35,36]. However, the low level of productivity of glu-independent bacteria has led to the development of genetically modified strains presenting a heterologous glu biosynthetic pathway $[37,38]$. In recent years, different heterologous hosts have been postulated as effective PGA producers, including Escherichia coli and Corynebacterium glutamicum [39,40].

The molecular machinery involved in PGA synthesis is organized in B. subtilis in an operon containing the synthase complex PgsBCA, the downstream gene $p g s E$, and the peptidase PgdS [41]. PgsB and PgsC form the active site of the synthase complex, in which ATP binds the $\gamma$-carboxyl group of a glu residue and is then eliminated by the amino group of another glu molecule by means of a nucleophilic attack, resulting in an $n+1$ chain. PgsA then becomes involved in removing the elongated chain from the active site in order to enable another monomer to be added. The role of $p g s E$, located downstream of $p g s B C A$, is still under debate [36]. The $p g s B C A$ operon is controlled by both intracellular DegS/DegU twocomponent and quorum-sensing systems [42]. Finally, PgdS is an endoamydase involved in PGA chain cleavage and the release of the PGA chain into the medium (Figure 4).

The preference for carbon source is strain-dependent, with glucose generally favoring PGA production [35]. The endogenous production of glu is driven by carbon catabolism through the TCA cycle, from which the $\alpha-K G$ intermediate serves as a direct precursor of glu in a reaction mediated by glu dehydrogenase (GDH). Glu can also be obtained from the glu-glutamine cycle by the transference of the amino group from glutamine to $\alpha-K G$ by glutamate synthase (GOGAT). Conversely, exogenously provided glu can be directly 
included in PGA growing chains. Conversion of L-glu to its D enantiomer, necessary for some Bacillus' peptidoglycan, as well as for those species producing D-PGA or D/L-PGA, is catalyzed by glu racemases ( $\mathrm{racE} / \mathrm{glr}$ and $\mathrm{yrpC}$ in B. subtilis) or in an indirect reaction by means of 3 enzymes (L-glu-pyruvic acid aminotransferase, L-alanine racemase, and D-glu-pyruvic acid aminotransferase) (Figure 4) [34]. Importantly, many Bacillus species produce different EPSs that, besides diverting resources from PGA production, hinder PGA recovery and purification [43].

\subsection{Main Properties of Natural Model Biopolymers}

Bacterial biopolymers have found their place in the biomedical field due to the properties they possess: (i) Most of them are biodegradable within the human body and, furthermore, their degradation rate can be tuned to meet the required shelf-life, whereas nondegradable polymers can serve as permanent implant materials; (ii) they are biocompatible, and their degradation compounds are nontoxic, nonimmunogenic, and noncarcinogenic; and (iii) they present adequate and tailorable mechanical and thermal properties for different applications. In this section, we focus on the properties of raw PHA, BC, and PGA, and, in Section 5, we analyze the possibilities of tuning their synthesis in order to generate specific properties.

One of the most valuable properties of bacterial polymers involves their biodegradability. Although BC, PHA, and PGA are degradable in nature, BC is not degraded in the human body due to the lack of efficient hydrolytic enzymes. Spontaneous degradation, which is still under debate, is possibly due to unspecific slow chemical hydrolysis, which makes BC a suitable material for long-term implants. However, attempts have been made to tune the degradability of this polymer (i.e., degradable NAcGlc-modified BC [44] or cellulase-conjugated BC; see Section 5 for more details). Conversely, both PHA and PGA are biodegradable in the human body. PHA is susceptible to nonspecific enzymatic degradation (i.e., lipases and esterases) [45]. Degradation rates strongly depend upon the enzymatic microenvironment of the target tissue as well as on monomer composition (e.g., length of the chain, presence of functional groups). Likewise, PGA has been reported to be rapidly hydrolyzed in vitro under acidic $(\mathrm{pH} 4)$ or basic conditions $(\mathrm{pH} 9)$ [46], proving to be rather stable under neutral conditions ( $\mathrm{pH} 7$ ). In addition, different enzymes can act on the peptide bonds, leading to subsequent degradation. These enzymes include human proteases such as trypsin and pronase E [47]. However, in vivo biodegradability of this polymer is still under research and appears to require a rather acidic environment [48].

Biocompatibility involves eliciting a proper host response upon implantation; it refers to the absence of cytotoxicity, genotoxicity, hemolysis, carcinogenicity, oxidative stress, or immune response, among others. Since biopolymers are degraded into common cellular building blocks, such as sugars, amino acids, or fatty acids, they are generally biocompatible. BC and PHA have proven to be biocompatible in multiple in vitro and in vivo studies (hemocompatibility, cell attachment, proliferation, toxicity, and metabolic assays) [49,50], although attention must be paid to the purification process to ensure endotoxin removal when producing PHA in Gram-negative strains. Furthermore, its degradation products-R3-hydroxyacids-are nontoxic to the human body and have a much weaker impact on local $\mathrm{pH}$ than their synthetic counterparts (i.e., poly lactic acid). For instance, 3-hydroxybutyrate, a degradation product of $\mathrm{P}(3 \mathrm{HB})$, is a natural component of human blood. Similarly, PGA and its degradation compounds L- and D-glu have been extensively proven to be biocompatible in vitro [51] and in vivo [52].

Material chemical and mechanical properties are key parameters that determine the feasibility of manipulation and molding. Additionally, with regard to application, they create the proper microenvironment for cell growth, which is known to be driven by stiffness sensing [53], and determine water availability (hydrophilicity and hygroscopic properties). We subsequently highlight the material properties of raw BC. Although PHA and PGA can be employed directly in some applications, they are more likely to be used 
after chemical modification or mixed with other materials, a fact that can greatly affect the properties described in the following paragraphs.

$\mathrm{BC}$, which is naturally synthesized as a hydrogel, possesses a Young's modulus $(E)$ of 15-30 GPa, average tensile strength $\left(\sigma_{\mathrm{t}}\right)$ of $250 \mathrm{MPa}$, and an elongation at break $\left(\varepsilon_{\mathrm{b}}\right)$ of $10 \%$ [54]. These parameters are in the order of the values for soft tissues. Nonetheless, it is interesting to note that the values vary greatly from one strain to another and according to culture conditions. Unlike plant cellulose, BC can be molded upon production; it is synthesized chemically pure, and its degree of polymerization is higher than that of plant cellulose (800-10,000 vs. 700-1400) [55]. The 3D network structure of BC exhibits a high degree of crystallinity $(60-80 \%)$, which accounts for its thermal stability [56]. Moreover, its structure confers on $\mathrm{BC}$ a high aspect ratio, resulting in a large surface area, with free hydroxyl groups that provide BC with good water-holding capacity (WHC), up to $99 \%$ of its total weight [56]. Dehydrated BC is rarely applied in the biomedical field. BC subjected to thermal drying displays 14 times less WHC than in its native (hydrated) form. Additionally, a significantly higher rate of deformability (2.7-fold, measured as $\varepsilon_{b}$ ) was found for the hydrated form than for dry BC. Conversely, Young's modulus and $\sigma_{t}$ were found to be higher for the dried form [57]. These parameters are summarized in Table 2.

Table 2. Mechanical and material properties of BC produced by different Komagataeibacter strains.

\begin{tabular}{|c|c|c|c|c|c|c|}
\hline Producing Species & $\begin{array}{c}\text { WHC }^{1} \\
(\%)\end{array}$ & $\begin{array}{c}E^{2} \\
(\mathrm{MPa})\end{array}$ & $\begin{array}{c}\sigma_{\mathrm{t}}^{3} \\
(\mathrm{MPa})\end{array}$ & $\mathcal{E}_{\mathrm{b}}{ }^{4}(\%)$ & $\mathrm{CI}^{\mathrm{XRD} 5}$ & Ref. \\
\hline \multicolumn{7}{|l|}{ K. xylinus } \\
\hline B12068 & NR & 3.73 & NR & 12.5 & 0.65 & [58] \\
\hline ATCC 10245 & 5400 & 2.87 & 0.36 & 18.6 & NR & [59] \\
\hline NBRC 13693 & 16,500 & 3.1 & 0.62 & 18.7 & NR & [59] \\
\hline ATCC 53524 & NR & 9.09 & 1.68 & 26.9 & NR & [60] \\
\hline ATCC 23760 & 18,000 & 1.5 & 46.9 & 2.5 & 0.85 & [61] \\
\hline \multicolumn{7}{|l|}{ K. medellinensis } \\
\hline ID13488 & 7218 & 6.75 & 50 & NR & 0.89 & [62] \\
\hline \multicolumn{7}{|l|}{ K. sucrofermentans } \\
\hline ATCC 700178 & 52,600 & 1.1 & 0.15 & 20.72 & NR & [59] \\
\hline DSM 15973 & 260 & NR & NR & NR & 0.87 & [63] \\
\hline \multicolumn{7}{|l|}{ K. hansenii } \\
\hline ATCC 23769 & 45,000 & 1.26 & 0.12 & 17.9 & NR & [59] \\
\hline GA2016 & 700 & NR & NR & NR & 0.87 & [64] \\
\hline \multicolumn{7}{|l|}{ K. rhaeticus } \\
\hline AF-1 & 14,000 & 3.2 & 46.9 & 1.5 & 0.89 & [61] \\
\hline
\end{tabular}

Reported properties of hydrated BC produced in Hestrin-Schramm (HS) culture medium with glucose as the carbon source. ${ }^{1}$ WHC: water-holding capacity. ${ }^{2} E$ : elastic modulus. ${ }^{3} \sigma_{\mathrm{t}}$ : tensile strength. ${ }^{4} \varepsilon_{\mathbf{b}}$ : elongation at break. ${ }^{5} \mathrm{CI}^{\mathrm{XRD}}$ : crystallinity index. NR: not reported.

PHAs constitute a whole family, and their mechanical and thermal properties vary greatly according to the composition of the monomer and the molecular weight of the polymer. Scl-PHAs are highly crystalline, brittle, and stiff [65], whereas mcl-PHAs are thermoplastic elastomers presenting a high degree of elasticity; both polymers exhibit low oxygen permeability and high water resistance $[65,66]$. For instance, $\mathrm{P}(3 \mathrm{HB})$ presents an $E$ of $3.5 \mathrm{GPa}$, a $\sigma_{\mathrm{t}}$ of $40 \mathrm{MPa}$, and an $\varepsilon_{\mathrm{b}}$ of $6 \%$, while mcl-PHA poly(3-hydroxydecanoate) (P(3HD)) presents an $E$ of $19.8 \mathrm{MPa}$, a $\sigma_{\mathrm{t}}$ of $12 \mathrm{MPa}$, and an $\varepsilon_{\mathrm{b}}$ of ca. $300 \%$ [67]. Some of these properties are summarized in Table 3 for various PHAs and will determine the target applications of the material. 
Table 3. Thermal and mechanical properties of some representative polymers from the PHA family.

\begin{tabular}{|c|c|c|c|c|c|c|c|}
\hline Polymer & $\begin{array}{l}\text { Copolymer } \\
\text { Content (\%) }\end{array}$ & $\begin{array}{c}E^{1} \\
(\mathrm{MPa})\end{array}$ & $\begin{array}{c}\sigma_{\mathrm{t}}^{2} \\
(\mathrm{MPa})\end{array}$ & $\begin{array}{l}\varepsilon_{b}^{3} \\
(\%)\end{array}$ & $\begin{array}{l}T_{m}{ }^{4} \\
\left({ }^{\circ} \mathrm{C}\right)\end{array}$ & $\begin{array}{l}T_{g}{ }^{5} \\
\left({ }^{\circ} \mathrm{C}\right)\end{array}$ & Ref. \\
\hline \multicolumn{8}{|l|}{$\begin{array}{l}\text { PHA } \\
\text { (R)-alkanoic }\end{array}$} \\
\hline $\mathrm{P}(3 \mathrm{HB})$ & 100 & $3500-4000$ & 40 & $3-8$ & $173-180$ & $5-9$ & [68] \\
\hline \multirow[t]{2}{*}{$\mathrm{P}(4 \mathrm{HB})$} & 100 & 70 & 50 & 1000 & 60 & -51 & [69] \\
\hline & $(97: 3)$ & 2900 & 38 & - & 170 & - & \\
\hline \multirow[t]{2}{*}{$\mathrm{P}(3 \mathrm{HB}-c o-3 \mathrm{HV})$} & $(91: 9)$ & 1900 & 37 & - & 162 & - & [70] \\
\hline & $(75: 25)$ & 700 & 30 & - & 137 & - & \\
\hline \multirow[t]{2}{*}{$\mathrm{P}(3 \mathrm{HB}-c o-4 \mathrm{HB})$} & $(97: 3)$ & $\mathrm{NR}^{6}$ & 28 & 45 & 166 & & \\
\hline & $(90: 10)$ & NR & 24 & 252 & 159 & & [/1] \\
\hline \multirow[t]{2}{*}{ P(3HB-co-3HHx) } & $(88: 12)$ & 1286 & 18.3 & 3.6 & 170 & & \\
\hline & $(45: 55)$ & 1207 & 21.6 & 4.1 & 167 & & {$[/ 2]$} \\
\hline P(3HD-co-3HDD) & $(15.7: 84.3)$ & 103.13 & 5.24 & 88.30 & 77.62 & 32.49 & [67] \\
\hline \multicolumn{8}{|l|}{ (R)-Aromatic } \\
\hline $\mathrm{P}(3 \mathrm{HPhHHx})$ & 100 & NR & NR & NR & NR & -1.3 & [73] \\
\hline $\mathrm{P}(3 \mathrm{HB}-c o-3 \mathrm{H} 3 \mathrm{PhP})$ & $(89.5: 8.9)$ & NR & NR & NR & 135,149 & 14.6 & [74] \\
\hline \multirow[t]{2}{*}{ P(3HDD-co-3H5PhV) } & $(97.1: 2.9)$ & 93.9 & 2 & 37.38 & 81 & -33.4 & [75] \\
\hline & $(68.1: 31.9)$ & 48.7 & 3.15 & 32.2 & 75.84 & -35.2 & [75] \\
\hline \multicolumn{8}{|l|}{ (R)-Nitrogen } \\
\hline $\mathrm{P}(3 \mathrm{H}-\mathrm{p}$-nitroPV-co-3HN) & $(4-7 \% \mathrm{~N})$ & NR & NR & NR & 56.4 & $\begin{array}{c}-35.9 \\
28.7\end{array}$ & [76] \\
\hline \multicolumn{8}{|l|}{ (R)-Sulfur } \\
\hline PHACOS & $\begin{array}{l}\text { (16.5 to } 77 \% \\
\text { thiolated side } \\
\text { chains) }\end{array}$ & NR & NR & NR & - & -5 & [77] \\
\hline \multicolumn{8}{|l|}{ (R)-Halogenated } \\
\hline $\mathrm{P}(3 \mathrm{HB})-\mathrm{Cl}$ & $(22 \% \mathrm{Cl})$ & NR & NR & NR & 134 & 2 & [78] \\
\hline $\mathrm{P}(\mathrm{FHB}-\mathrm{co}-\mathrm{HB})-\mathrm{F}$ & $(7 \% \mathrm{~F})$ & NR & NR & NR & $\begin{array}{l}160.5 \\
173.6\end{array}$ & -0.8 & [79] \\
\hline
\end{tabular}

${ }^{1}$ E: elastic modulus. ${ }^{2} \sigma_{\mathrm{t}}$ : tensile strength. ${ }^{3} \varepsilon_{\mathrm{b}}$ : elongation at break. ${ }^{4} T_{m}$ : melting temperature. ${ }^{5} T_{g}$ : glass transition temperature. ${ }^{6} \mathrm{NR}:$ not reported. $\mathrm{P}(3 \mathrm{HB}-c o-3 \mathrm{H} 3 \mathrm{PhP})$ : poly(3HB-co-3-hydroxy-3-phenylpropionate); $\mathrm{P}(3 \mathrm{HPhHHx})$ : poly(3-hydroxyphenylhexanoate); $\mathrm{P}(3 \mathrm{HDD}-$ 3H5PhV): poly(3-hydroxydodecanoate-co-3-hydroxy-5-phenylvalerate; $\mathrm{P}(3 \mathrm{H}-\mathrm{p}$-nitroPV-co-3HN): poly[3-hydroxy-5-(4-tolyl)valerate]-co3-hydroxynonanate; PHACOS: poly(3-hydroxyoctanoate-co-3-hydroxyhexanoate-co-6-acetylthioalcanoate).

Furthermore, PGA is a water-soluble anionic polymer when it forms salts with cations, whereas its free acid form is insoluble in water. The conformation and viscosity of PGA in solution is $\mathrm{pH}$-dependent, which calls for the creation of $\mathrm{pH}$-responsive materials. PGA in its acid form presents a rod-like shape with an $\alpha$-helix secondary structure, whereas NaPGA folds preferentially into random coils, acquiring a sphere-like conformation [80]. As a raw biomaterial, its principal properties involve its highly hygroscopic and moisturizing effects, comparable to those of hyaluronic acid.

\section{Sustainable Production of Bacterial Polymers}

The three model biopolymers addressed in the present paper are produced by means of biotechnological processes based on different strategies in terms of bioprocess engineering. However, all three are produced from renewable sources such as waste streams. This section first provides a general description of each bioprocess, subsequently giving an overview of their production from different feedstocks.

\subsection{General Aspects of the Bioprocess}

BC synthesis by the Komagataeibacter genus is characterized by its low titer, yield, and productivity. This is mainly due to two essential features of the process. On the one hand, production is coupled to growth, with production strains presenting low growth 
rates. On the other hand, production mainly relies on static culture strategies to avoid the induction of B- defective phenotypes, which reduces BC yield and alters its mechanical properties [81]. Under static conditions, oxygen is less available and growth is diminished, but the downstream process is facilitated; this consists of removing the membrane from the air-medium interface, boiling it with $\mathrm{NaOH}$, and rinsing it with water until the $\mathrm{pH}$ becomes neutral [82]. Although there is abundant literature on the development of bioreactors, which has been revised elsewhere [83], configurations preventing the loss of mechanical properties and providing high titer production have not yet been achieved. Due to the scant arsenal of available molecular biology techniques applied to BC-producing bacteria, attempts to enhance BC production are predominantly based on the replacement of the culture medium or carbon source with wastes as an alternative feedstock $[62,84,85]$.

The operational mode for the industrial production of PHAs depends on the producing strain selected. Traditional production relies on pure culture strategies, in which PHA accumulation is initiated upon nutrient imbalance. This production strategy is oriented towards high cell density cultivation. Although batch productions are also used, fed-batch strategies have been shown to provide the highest PHA production yields. Fed-batch cultures are fed with nutrient sources, enabling periods of growth and PHA accumulation, thus maximizing cell growth [86]. Alternative strategies, however, such as mixed microbial cultures in which fast-famine periods are alternated, have proven to generate high PHA accumulation and productivity while avoiding the need for sterility during the process [87]. The intracellular location of the product determines the particular characteristics of its costly downstream processing due to the fact that cell lysis and dissolution of the polymer in non-ecofriendly organic solvents are needed for polymer purification. Much work has been done to increase the cost-effective production of PHAs; this includes metabolic engineering, bioprocess optimization, and the aforementioned design of mixed culture strategies, which considerably reduce operating costs [88,89].

PGA is currently produced by bacteria by means of submerged or solid-state fermentation (SSF) [90]. Different Mw PGA (from 100 to $>1000 \mathrm{kDa}$ ) and enantiomeric compositions of the polymer can be produced via different species, carbon sources, and feeding strategies [35]. Productivity and purity may vary dramatically according to culture conditions such as ionic strength, aeration, temperature, and culture time. Production costs remain high, and this hinders the rollout of a wide range of PGA applications; consequently, recent research focuses on metabolic engineering aimed at precursor overproduction (glu) by means of inexpensive carbon sources [91]. Additionally, SSF, a less power-demanding culture strategy, has provided encouraging results; it has therefore been proposed as an economical alternative to PGA production [91,92]. PGA can be processed downstream by precipitation through reduction of solubility (i.e., ethanol addition), via precipitation by complex formation with cations, or by filtration [93].

\subsection{Bacterial Biopolymer Production from Renewable Sources}

Sustainable production of bacterial biomaterials relies on the use of inexpensive, alternative, and renewable carbon sources as feedstock. Hence, byproducts from other processes and waste streams for use as substrates and the integration thereof into biorefineries would significantly enhance the economic competitiveness of bacterial polymers. For instance, industrial- or pilot-scale production of PHAs and BC is now a reality in waste management plants. These strategies are summarized in Figure 5. 


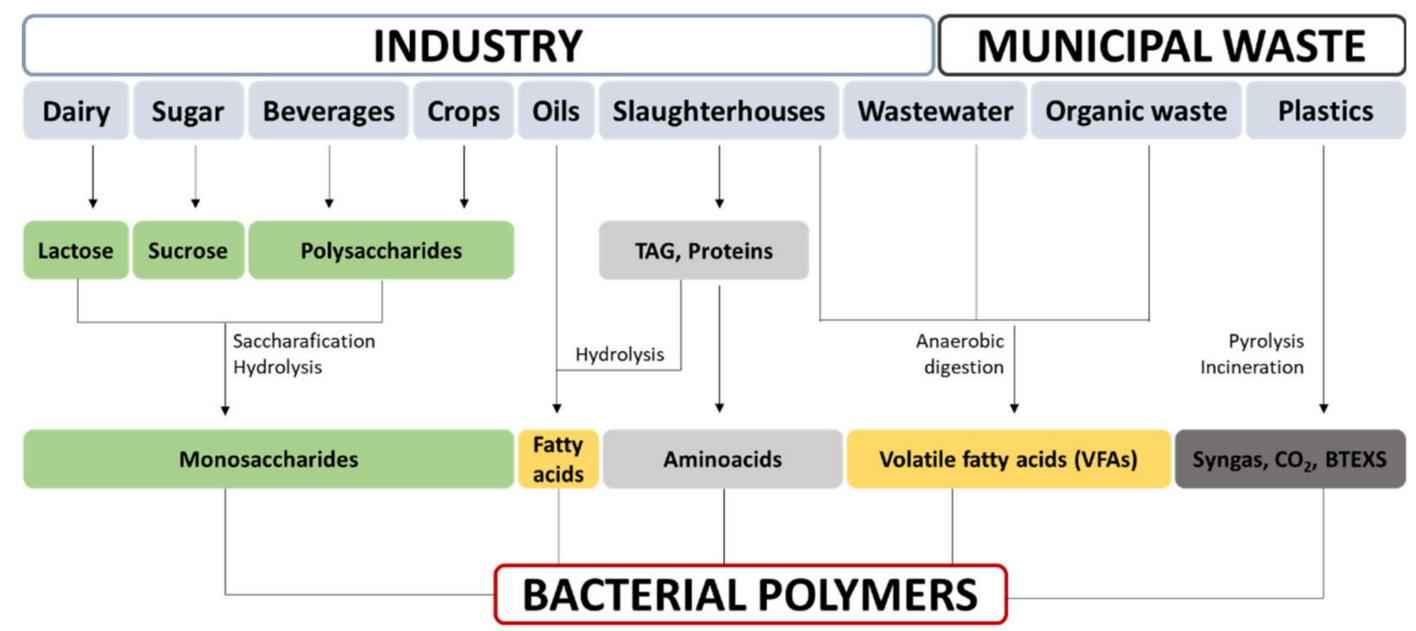

Figure 5. Flowchart of industrial and municipal upcycling of residues into bacterial polymers. Box colors indicate the highest percentage of carbon source in composition: green (saccharides), yellow (lipids, fatty acids), light grey (aminoacids), and dark grey (recalcitrant compounds: syngas, $\mathrm{CO}_{2}$, aromatics, and BTEXS. BTEXS includebenzene, ethylbenzen, toluene and xylene. Processes or treatments transforming the raw residues into bacteria assimilable substrates are indicated.

Industrial food waste constitutes one of the principal feedstocks employed for biopolymer production. These sources are frequently acidic and of undefined composition, which pose environmental issues; furthermore, they have a negative impact on the environment when disposed of. Although they are suitable for microbial fermentation, their complex nature means that they are rarely used directly in culture media [88]. Previous treatment might therefore be required, depending on the composition, concentration, and purity of the waste as well as the microbial biocatalyst applied in the process [94]. Table 4 shows the suitability of wastes from different food industries for the production of bacterial biopolymers.

In this sense, whey is highly relevant. It is the main byproduct of dairy industries, and its estimated global annual production is over $100 \times 10^{6}$ tons. Moreover, $47 \%$ of this waste is being poured straight down the drain [95]. In any case, the capacity to metabolize lactose is not common among bacteria. Indeed, very few PHA- or BC-producing organisms are able to produce polymers from it. Exceptions include some strains of B. megaterium, Burkhodelia cepacea, or Methylobacterium [96]. In order to identify new efficient PHA producers from whey, in silico prospection has proven to constitute a successful strategy. For instance, Caulobacter segnis DSM 29236 accumulates 37\% of cell dry weight (CDW) in PHB, producing $9.3 \mathrm{~g} \mathrm{~L}^{-1}$ in fed-batch cultures [97]. Conversely, the lactose monomers, glucose and galactose, are commonly mineralized by many bacteria; consequently, a hydrolytic pretreatment could broaden the range of bacteria capable of fermenting such a waste stream. For example, BC production in diluted hydrolyzed whey media resulted in $0.25 \mathrm{~g} \mathrm{~L}^{-1}$ day $^{-1}$ BC productivity by K. xylinus PTCC 1734 [85].

Entire or partial residues from crops are also predominant among biowastes produced worldwide [98]; they are frequently applied in sustainable processes for bacterial biopolymer production. A saccharification pretreatment is often needed to hydrolyze the complex carbohydrates present in such lignocellulosic residues. For instance, rice straw requires alkali treatment followed by enzymatic hydrolysis for PHA production, yielding $3.4 \mathrm{~g} \mathrm{~L}^{-1}$ of PHA in the case of Burkholderia cepacia JCM15050 [99]. Alternatively, this raw material can be pretreated with acids in combination with enzymatic hydrolysis, rendering xylose and glucose, used, for example, for PGA production by B. subtilis NX-2 [92]. Another example involves the hydrolysis of potato peels with nitric acid, the subsequent hydrolysate of which, fermented by G. xylinum ATCC 10245, yielded $0.65 \mathrm{~g} \mathrm{~L}^{-1}$ day $^{-1}$ of BC [100]. BC can also be produced from an apple-pomace-based medium by K. medenillensis ID13488 fermentation (12.5 $\mathrm{g} \mathrm{L}^{-1}$ of $\left.\mathrm{BC}\right)$. This feedstock is a byproduct of the cider production 
industry, consisting of peels, seeds, cores, and pulp [62]. Recently, a pilot-scale study on $\mathrm{BC}$ production from saccharified oat hulls via sequential acid-alkali treatment exhibited outstanding yields of 80.5 tons of BC per 100 tons of hydrolysate when fermented by a microbial consortium [101]. SSF is often used for PGA production because it is more economical in terms of water consumption and energy power. For example, soybean meal and corn straw (CS) fermentation by B. amyloliquefaciens JX-6 was scaled up to $50 \mathrm{~L}$, reaching $116 \mathrm{~g}$ PGA per $\mathrm{Kg}$ of residue [91].

Molasses, a well-known waste stream from the sugar industry, containing up to $50 \%$ sucrose, has frequently been investigated due to its potential for the production of biopolymers. Mixed and pure culture strategies have demonstrated the efficiency of this process in many bacterial strains such as B. megaterium BA-019, which has achieved $30.5 \mathrm{~g} \mathrm{~L}^{-1}$ [102]. Likewise, the high fermentable sugar content of molasses renders it a suitable feedstock for $\mathrm{BC}$ production. For instance, acidic pretreatment hydrolysis enhanced BC production of G. xylinus subsp. sucrofermentans up to $5.3 \mathrm{~g} \mathrm{~L}^{-1}$ in a corn step liquor (CSL)-molasses medium [103]. Finally, molasses directly fermented upon supplementation with monosodium glu waste liquor (MGWL) by B. subtilis NX-2 yielded a $50 \mathrm{~g} \mathrm{~L}^{-1}$ titer of PGA [104]. Additionally, nonsterile SSF of B. subtilis NX-2 immobilized onto sugarcane bagasse and used for cane molasses fermentation displayed an average titer of $90.6 \mathrm{~g} \mathrm{~L}^{-1}$ [105].

Interestingly, oil-derived feedstock such as household or industrial wastes can be used as a carbon source without the need for pretreatment to produce PHAs [106]. Some studies have demonstrated that $C$. necator $\mathrm{H} 16$ can use waste oil from sesame, palm, and sunflower to produce up to $105 \mathrm{~g} \mathrm{~L}^{-1}$ of PHB [107-109]. Furthermore, mcl-PHA production from used cooking oil has been tested [110]. Interestingly, supplementation of the standard BC production medium (HS) with 1\% rapeseed oil raised BC production 6-fold, from 1 to $6 \mathrm{~g} \mathrm{~L}^{-1}$, in K. xylinus DSM 46602 cultures; this was due to certain physical phenomena, e.g., favoring oxygen exchange within deeper layers of cellulose [111].

Table 4. Sustainable production of bacterial polymers from industrial and municipal waste.

\begin{tabular}{|c|c|c|c|c|}
\hline Waste Origin & Strain & $\begin{array}{l}\text { Productivity } \\
\left(\mathrm{g} \mathrm{L}^{-1} \text { day }^{-1}\right)\end{array}$ & Type of Polymer & Ref. \\
\hline \multicolumn{5}{|l|}{ Cheese whey } \\
\hline & Alcaligenes latus & 2.64 & $\mathrm{P}(3 \mathrm{HB})$ & [112] \\
\hline & Caulobacter segnis & 4.56 & $\mathrm{P}(3 \mathrm{HB})$ & [97] \\
\hline & Haloferax mediterranei & 4.04 & $\mathrm{P}(3 \mathrm{HB})$ & [113] \\
\hline & $\begin{array}{l}\text { C. necator DSM } 545 \\
\text { (recombinant strain) }\end{array}$ & 0.82 & $\mathrm{P}(3 \mathrm{HB})$ & [114] \\
\hline & K. sucrofermentans DSM No 15973 & 2.7 & $\mathrm{BC}$ & [115] \\
\hline & Acetobacter strain ITDI 2.1 (recombinant strain) & 0.1 & $\mathrm{BC}$ & [116] \\
\hline \multicolumn{5}{|l|}{ Cane molasses } \\
\hline & Pseudomonas & 2.17 & (P3HO-co-3-HHx) & [117] \\
\hline & B. megaterium BA-019 & 30.48 & $\mathrm{P}(3 \mathrm{HB})$ & [102] \\
\hline & Mixed culture & 10.93 & mcl-PHA & [118] \\
\hline & A. xylinum BPR 2001 & 1.77 & $\mathrm{BC}$ & [103] \\
\hline & A. pasteurianus RSV-4 yielded & 0.51 & $\mathrm{BC}$ & [119] \\
\hline & B. subtilis NX-2 & 12.96 & PGA & [104] \\
\hline & B. subtilis NX-2 & 25.92 & PGA & [105] \\
\hline
\end{tabular}


Table 4. Cont.

\begin{tabular}{|c|c|c|c|c|}
\hline Waste Origin & Strain & $\begin{array}{l}\text { Productivity } \\
\left(\mathrm{g} \mathrm{L}^{-1} \text { day }^{-1}\right)\end{array}$ & Type of Polymer & Ref. \\
\hline \multicolumn{5}{|l|}{ Crops } \\
\hline \multirow[t]{2}{*}{ Vinasse } & H. mediterranei & 5.04 & $\mathrm{P}(3 \mathrm{HB}-\mathrm{co}-3 \mathrm{HV})$ & [120] \\
\hline & H. marismortui & 0.48 & $\mathrm{P}(3 \mathrm{HB})$ & [120] \\
\hline \multirow[t]{2}{*}{ Sugarcane bagasse } & C. necator & 3.16 & $\mathrm{P}(3 \mathrm{HB})$ & [121] \\
\hline & B. серасіа IPT 048 & 11.28 & $\mathrm{P}(3 \mathrm{HB})$ & [122] \\
\hline Grape pomace & P. putida KT2440 & 1.2 & $\mathrm{P}(3 \mathrm{HO}-c o-3-\mathrm{HHx})$ & [123] \\
\hline Waste beer yeast & $\begin{array}{c}\text { G. hanseii } \\
\text { CGMCC } 3917\end{array}$ & 0.514 & , & [124] \\
\hline Apple pomace & $\begin{array}{l}\text { K. medenillensis } \\
\text { ID13488 }\end{array}$ & 0.177 & $\mathrm{BC}$ & [62] \\
\hline Potato peel & G. xylinum ATCC 10245 & 0.65 & $\mathrm{BC}$ & [100] \\
\hline Citrus peel & K. xilynus CICC No 10529 & 0.712 & $\mathrm{BC}$ & [125] \\
\hline Orange juice & A. xylinum NBRC 13693 & 0.421 & $\mathrm{BC}$ & [126] \\
\hline Litchi extract & G. xylinus $\mathrm{CH} 001$ & 0.18 & $\mathrm{BC}$ & [127] \\
\hline Citrus waste & K. sucrofermentans DSM 15973 & 0.515 & $\mathrm{BC}$ & [128] \\
\hline Coffee cherry husk & G. hanseii UAC 09 & 0.547 & $\mathrm{BC}$ & [129] \\
\hline Olive oil mills & G. sacchari & 0.212 & $\mathrm{BC}$ & [130] \\
\hline Tomato juice & A. pasteurianus RSV-4 & 0.68 & BC & [119] \\
\hline \multirow[t]{2}{*}{ Rice straw } & B. серсесеа USM (JMC 15050) & 1.95 & $\mathrm{P}(3 \mathrm{HB})$ & [99] \\
\hline & B. subtilis NX-2 & 0.87 & PGA & [92] \\
\hline $\begin{array}{l}\text { Soybean meal } \\
\text { and Corn straw }\end{array}$ & B. amiloliquefaciens JX-6 & $116\left(\mathrm{~g} \mathrm{~kg}^{-1}\right)$ & PGA & [91] \\
\hline Soybean straw & B. amiloliquefaciens NX-2S & $65.79\left(\mathrm{~g} \mathrm{~kg}^{-1}\right)$ & PGA & [131] \\
\hline \multicolumn{5}{|l|}{$\begin{array}{l}\text { Household and } \\
\text { industrial oils }\end{array}$} \\
\hline Sesame & C. necator H16 & 31.32 & $\mathrm{P}(3 \mathrm{HB})$ & $\begin{array}{l}{[107,} \\
109]\end{array}$ \\
\hline Sunflower & C. necator H16 & 35.04 & $\mathrm{P}(3 \mathrm{HB})$ & $\begin{array}{l}{[107,} \\
109]\end{array}$ \\
\hline Canola & Wautersia eutropha ATCC 17699 & 10.96 & $\mathrm{P}(3 \mathrm{HB})$ & [132] \\
\hline Cooking & P.aeruginosa $42 A 2$ & 0.76 & $\mathrm{P}(3 \mathrm{HB})$ & [110] \\
\hline Palm & C. necator H16 & 4.2 & $\mathrm{P}(3 \mathrm{HB})$ & [108] \\
\hline Rapeseed & K. xylinus DSM 46602 & 6 & $\mathrm{BC}$ & [111] \\
\hline \multicolumn{5}{|l|}{ Waste water } \\
\hline Fruit processing & Halomonas i4786 & 1.8 & $\mathrm{P}(3 \mathrm{HB})$ & [133] \\
\hline Alcohol distillery & $\begin{array}{l}\text { K. saccharivorans } \\
\text { BC1 }\end{array}$ & 0.155 & $\mathrm{BC}$ & [134] \\
\hline Rice wine distillery & $\begin{array}{c}\text { G. xilynus } \\
\text { BCRC12334 }\end{array}$ & 1 & $\mathrm{BC}$ & [135] \\
\hline Lipid fermentation & $\begin{array}{l}\text { G. xylinus } \\
\text { CH001 }\end{array}$ & 0.1 & $\mathrm{BC}$ & [136] \\
\hline $\begin{array}{c}\text { Hot water wood sugar } \\
\text { extraction }\end{array}$ & $\begin{array}{l}\text { A. xylinus } \\
23769\end{array}$ & 0.019 & $\mathrm{BC}$ & [137] \\
\hline Butanol fermentation & $\begin{array}{l}\text { G. xylinus } \\
\text { CH001 }\end{array}$ & 0.17 & $\mathrm{BC}$ & [138] \\
\hline Jujube & $\begin{array}{c}\text { G. xylinys } \\
\text { CGMC2955 }\end{array}$ & 0.375 & $\mathrm{BC}$ & [139] \\
\hline \multicolumn{5}{|l|}{$\begin{array}{l}\text { WW anaerobically } \\
\text { fermented to VFAs }\end{array}$} \\
\hline Municipal & Activated sludge & 1.37 & $\mathrm{P}(3 \mathrm{HB}-c o-3 \mathrm{HV})$ & [140] \\
\hline Paperboard mill & Activated sludge & 3 & $\mathrm{P}(3 \mathrm{HB}-c o-3 \mathrm{HV})$ & [141] \\
\hline Candy factory $\mathrm{f}$ & Plasticicumulans acidivorans & 0.05 (gPHA/gVSS) & $\mathrm{P}(3 \mathrm{HB}-\mathrm{co}-3 \mathrm{HV})$ & [142] \\
\hline Urban waste & Activated sludge & 0.65 (gPHA/gVSS) & $\mathrm{P}(3 \mathrm{HB}-c o-3 \mathrm{HV})$ & [143] \\
\hline $\begin{array}{l}\text { Sewage sludge and } \\
\text { municipal }\end{array}$ & Activated sludge & 8.64 & scl-PHA & [144] \\
\hline
\end{tabular}




\section{Major Biomedical Applications of Model Bacterial Biopolymers \\ 4.1. Drug Delivery Systems}

Drug delivery systems constitute an area of biomedicine that is growing exponentially because these systems present numerous advantages over conventional formulations, such as increased drug solubility, bioavailability, and shelf life. They also reduce systemic side effects as systems can be engineered to target specific tissues or cells [145]. Polymeric materials are garnering much attention in this field because they provide delivery systems exhibiting stealth properties that help to evade early macrophage phagocytosis and immune response to carriers [146]. Furthermore, release kinetics can be tuned by varying the $\mathrm{Mw}$ of the polymer or through chemical modifications to meet specific needs (see Section 5).

Different formulations exist for polymeric drug delivery systems. The most common are particles, namely, capsules and spheres, either at the micro-scale or the nano-scale, due to their ease of preparation, their high drug loading capacity, and, in the case of nanoparticles, their ability to pass through different body barriers depending on the nature of polymer [147]. Particles have been developed to release a wide range of molecules, from small pharmaceuticals to therapeutic proteins. Although early research focused on synthetic polymers such as polyethyleneglycol or polylactic acid, degradable biopolymers have aroused interest in recent years due to their biocompatibility, biodegradability, and tailorable properties. Moreover, bacterial polymers may be more tailorable than synthetic polymers with regard to presenting properties such as degradation rates and, thus, release rates. In this sense, $\mathrm{PHA}$ ter-polymer $\mathrm{P}(3 \mathrm{HB}-\mathrm{co}-3 \mathrm{HV}-\mathrm{co}-3 \mathrm{Hx})$ nanoparticles (NPs) loaded with immunosuppressant azathioprine (AZA) for systemic lupus erythematosus treatment displayed an enhanced in vivo therapeutic effect compared with PLA-loaded NPs or intravenous AZA administration. Due to their low degradation rate, a more sustained release over 15 days was achieved with PHA-AZA NPs compared with 4 days for total release for PLA-AZA NPs. Furthermore, PHA-AZA NPs showed a better biosafety profile due to a lower accumulation rate in the kidneys and less necrotic tissue in the liver [148]. In addition, the diversity of bacterial polymers can help to develop new routes of administration. As an example, PGA-functionalized chitosan nanoparticles (CS-PGA NPs) were used to develop oral formulations of insulin, in contrast with the standard transdermal delivery. Polymeric NPs were able to resist harsh gastric conditions, while the PGA coating increased intestinal uptake of the NPs via calcium-sensing receptors and amino acid transporters. Furthermore, in vivo assessment in Sprague-Dawley rats showed that CS-PGA NPs produced an increase in cumulative hypoglycemia 1.7 times greater than standard subcutaneous insulin administration, likely owing to a sustained release of insulin that was more similar to the physiological pattern [149].

$\mathrm{BC}$ is also thriving in the drug delivery field, particularly for cutaneous delivery systems, due to its high water-holding capacity (WHC). Interestingly, BC is naturally produced as a hydrogel with high water content and a high aspect ratio, which creates a suitable environment for the formation of $\mathrm{BC}$-bioactive molecules. BC hydrogels are generally incubated with the targeted drug, which becomes trapped in the BC network, is retained via $\mathrm{H}$-bonding with the hydroxyl groups, and can be subsequently released in the desired area [13]. For example, the antibiotic drug tetracycline hydrochloride was loaded onto $\mathrm{BC}$ membranes, which exhibited sustained release, prolonging the antibacterial effects of cutaneous administration of the drug [150]. Likewise, the anti-inflammatory diclofenac has been loaded into BC membranes; however, it displayed a very rapid release profile ( $>90 \%$ in $30 \mathrm{~min}$ ) [151].

\subsection{Tissue Engineering}

Tissue engineering is the area of biomedicine dealing with the regeneration of tissues, which generally involves the use of scaffolds, porous matrices that mimic the native ECM and temporarily support cell and tissue growth until their degradation after implantation. Key factors affecting the success of scaffolds engineered for cell growth involve: (i) mechanical properties similar to those of the native tissue, as these properties are known to drive 
cell differentiation and adhesion [53]; (ii) porosity of the scaffold, which is linked to the ability of cells to infiltrate and migrate, and neovascularization; (iii) ECM-like information in the form of adhesion motives or growth factors; and (iv) biodegradability, which, in many cases, is desirable. Bacterial polymers are becoming commonplace in this field because the abovementioned factors can be tuned with relative ease via biotechnological or chemical procedures (see Section 5). Typical scaffold fabrication techniques such as electrospinning, salt-leaching, solvent casting, and polymer crosslinking to formulate hydrogels (such as native BC), as well as emerging 3D scaffold printing, are revised elsewhere [152,153].

Bacterial polymers are increasingly used for tissue regeneration. By way of an example, for bone regeneration, macroporous scaffolds made up of $\mathrm{PHB} / \mathrm{BC}$ blends by means of salt leaching resulted in an interconnected porous structure with a pore size of $5-50 \mu \mathrm{m}$ and a Young's modulus of 1.2-14 GPa, within the range of bone rigidity (5-10 GPa). These structures supported 3T3-L1 preadipocytes, and BC enhanced in vivo differentiation into osteoblasts [154]. Other studies have demonstrated that PHB/nano-hydroxyapatite (PHB/nHA) composite scaffolds support and promote osteoblast cell growth [155]. In reference to skin regeneration, bacterial biopolymers were used to form porous BC scaffolds with gelatin-coated nanofibers, which displayed good adhesion and proliferation of keratinocytes, leading to $94 \%$ in vivo regeneration within 2 weeks in mice [156]. For cartilage regeneration, hydrogels generated by the crosslinking of thiolated PGA and glycyl-methacrylate-grafted PGA were formed. The resulting hydrogels showed a porous structure, elasticity (withstanding a $70 \%$ mechanical strain), and a compression modulus (up to $749 \mathrm{kPa}$ ) suitable for the recovery of cartilage [157]. For cardiac regeneration, $\mathrm{P}(3 \mathrm{HO}-$ co-3HD) / polycaprolactone (PCL) blends were designed to overcome the processability of mcl-PHA while enabling alteration of the mechanical properties of PCL. Additionally, 2D porous patches (100 $\mu \mathrm{m}$ pore size) were formulated by solvent casting, resulting in more effective mechanical properties $\left(200 \% \varepsilon_{\mathrm{b}}, 0.02-0.05 \mathrm{MPa} \sigma_{\mathrm{t}}, 1.5 \mathrm{MPa}\right.$ Young's Modulus) than those of the targeted tissue, capable of resisting the long-term stress/strain the myocardium is subjected to. Moreover, on seeding the scaffold with murine cardiac progenitor cells, the implanted device in mice showed good cell attachment and in vivo proliferation [158].

\subsection{Vascular Grafts, Cardiac Valves, and Vessel Stents}

Vascular diseases frequently necessitate a bypass or a vascular graft in order to properly redirect blood flow. Although large artificial vascular grafts are routinely used in clinical practice, small diameter grafts still pose a challenge, and autologous implants remaining the gold standard. For artificial grafts, nanosized $(<1 \mu \mathrm{m})$ structures are known to cause less coagulation or platelet adhesion than larger ones [159]. Therefore, BC has gained attention in this field due to its nanosized mesh structure. In a recent study by Wan et al., $\mathrm{BC} /$ cellulose acetate (CA) grafts with different diameters and polymer ratios were obtained at different fermentation times of K. xylinus upon a cylindrical CA electrospun structure. Grafts with a $6.1 \%(\mathrm{wt}) \mathrm{BC}$ content showed increased levels of tensile strength (1.2 MPa) and Young's modulus (3.5 MPa), with values comparable to those of human umbilical veins. Results showed that $\mathrm{BC} / \mathrm{CA}$ displayed better biocompatibility than $\mathrm{BC}$ or CA grafts separately as a lower inflammatory response and a thinner fibrotic capsule were observed [160].

Valve conditions frequently require surgical replacement with mechanical valves or homo- or xenografts. Although mechanical valves display better structural resistance, thrombotic complications constitute the main drawback. To address this issue, metallic valves have been coated with polymers to enhance biocompatibility. Due to their flexibility, mcl-PHAs are suitable polymers for valve coatings. For instance, when trileaflet-engineered valves of copolymer $\mathrm{P}(3 \mathrm{HHx}-\mathrm{co}-3 \mathrm{HO})$ were seeded with autologous ovine cells and implanted in the pulmonary position of lambs, no thrombus was formed, and only mild stenosis was observed for 120 days [161]. In another study, decellularized porcine aortic valves were coated with copolymer $\mathrm{P}(3 \mathrm{HB}-\mathrm{co}-\mathrm{HHx})$ and implanted in the pulmonary position in sheep. The coated valves resulted in improved tensile strength and reduced 
calcification, promoting repopulation with the native host's valve tissue, when compared with noncoated valves [162].

Other coronary diseases require implants such as cardiac stents, which have long been used to keep occluded vessels open; vascular congestion is a common condition derived from atherosclerosis. Although stents are fabricated from metals, polymer coatings may reduce the risk of thrombus. For instance, nitinol-PHA-coated stents displayed a lower inflammatory response as well as the absence of parietal thrombi and thinner intima thickness at the site of implantation when compared to nitinol implants; this points to PHA as a powerful coating material for vessel stents [163].

\subsection{Wound Healing}

An aging population, with the resulting increase in chronic wounds and ulcers, highlights wound treatment as another significant field in biomedicine. Wound healing is a complex dynamic biological process that implies ECM regeneration, cell growth, and secreted signaling factors. Wound dressings are now known to play an active role in healing as they substitute skin function during regeneration. Ideally, they should provide a moist environment, thermal insulation, and effective oxygen circulation; moreover, they should ensure liquid drainage and epithelial migration, aid in the absorption of wound exudates, and provide wound protection from bacterial loads [13].

$\mathrm{BC}$ meets most of these requirements or can be modified to this end (i.e., antibacterial activity; see Section 5). In particular, $\mathrm{BC}$ has demonstrated its effectiveness for burn patients because moisture is crucial for rapid healing. A recent prospective randomized clinical trial compared BC dressings (Epiprotect ${ }^{\circledR}$ S2Medical AB, Sweden) with the standard silver sulphadiazine treatment of partial-thickness burns. The results suggested that $B C$ dressings are the better first choice, as seen in rapid healing rates, low pain scores, and fewer dressings used [164]. Furthermore, wound healing is the field in which BC has largely reached the commercial level; several $\mathrm{BC}$-based dressings are currently sold on the market. For instance, Superabsorb ${ }^{\circledR} \mathrm{X}+\mathrm{PHMB}$ is the first BC combined drug delivery-wound healing patch on the market; it possesses healing and antimicrobial properties as it releases antiseptic polyhexamethylene biguanide. Other BC-based wound dressings are marketed as temporary skin substitutes (Biofill, Membracell, Bionext ${ }^{\circledR}$ ) or ulcerous wound dressings $\left(x C e l l\right.$, Bionext ${ }^{\circledR}$, Nanoskin $^{\circledR}$ ); these have recently been reviewed elsewhere [165].

Other biopolymers are also used for wound treatment. Dressings constructed from copolymer $\mathrm{P}(3 \mathrm{HB}-\mathrm{co}-4 \mathrm{HB})$ films and electrospun nanofiber membranes cultured with allogenic fibroblasts were assessed in a skin defect model; cells were observed to secrete ECM, forming a layer that promoted migration of the cells in the vicinity of the wound and thus, wound closure. This resulted in healing times 1.4 times faster than for noncarrying allogenic cells and 3.5 times faster than the ones healed under scars [166]. PGA has also been studied for wound dressings, although in combination with other polymers. Hydrogels of PGA with other polymers, for instance, gelatin, have been studied for wound regeneration. The PGA-gelatin hydrogels properly absorbed exudates and showed accelerated wound repair, outperforming the untreated group [167].

\subsection{Sutures and Biological Glues}

Sutures are designed to hold tissues together and accelerate healing processes while minimizing scar formation. There is currently a growing demand for suture materials as surgical procedures are increasing in number and because material requirements differ for each procedure [168]. Work is underway to develop second-generation sutures displaying bioactive functionalities, i.e., antimicrobial sutures for preventing surgery-associated infections [169] or absorbable sutures. Microbial polymers have found a niche in this field due to their tensile properties, which help to resist tissue-induced stress, and because of their ease of functionalization. For instance, $\mathrm{P}(4 \mathrm{HB})$ sutures were the first FDA-approved PHA-based device; they exhibit a tensile strength that outperforms that of commercially available monofilament sutures (545 MPa vs. $410-460 \mathrm{MPa}$ for polypropylene sutures), 
and they are highly flexible $\left(1000 \% \varepsilon_{b}\right)$ [69]. These sutures are now marketed under the ThephaFLEX trademark.

Alternatively, biological glues connect tissues without the need for sewing. PGAgelatin coupled with 1-(3-dimethylaminopropyl)-3-(ethylcarbodiimide) hydrochloride (EDC) displayed better implant-tissue interface adhesion than fibrin-based glues in a rat model. The mixed glues showed a greater bonding strength and shorter gelation times as the molecular weight of gamma-PGA or gelatin increased [170].

\section{Increasing Bacterial Polymers' Structural Diversity by In Vivo and In Vitro Functionalization}

The high degree of applicability of bacterial biomaterials can be enhanced by tailoring their properties; this can involve improving their mechanical properties or modulating their thermal properties for easier manipulation of the materials. Furthermore, new functionalities that do not exist in the native polymer can be conferred. For instance, degradation rates can be modulated by changing the polymer structure, which can lead to different release profiles; polymeric matrices can be enhanced for cell attachment, resulting in a faster migration rate for tissue engineering, or antimicrobial activity can be conferred for infection treatment (i.e., wound healing) or prevention (i.e., implants).

The following subsections show the strategies (Figure 6) for modifying the properties of biopolymers, mainly BC and PHA; in this sense, more detailed information is provided in the literature.

\begin{tabular}{|c|c|c|c|}
\hline \multicolumn{2}{|c|}{ BIOSYNTHETIC } & \multicolumn{2}{|c|}{ POSTBIOSYNTHETIC } \\
\hline $\begin{array}{l}\text { Metabolic } \\
\text { engineering }\end{array}$ & $\begin{array}{c}\text { In situ } \\
\text { modifications }\end{array}$ & $\begin{array}{l}\text { Peptidic affinity } \\
\text { functionalization }\end{array}$ & $\begin{array}{c}\text { Chemical } \\
\text { modifications }\end{array}$ \\
\hline
\end{tabular}

Figure 6. Flowchart of the different approaches used in the literature to modify bacterial polymers.

\subsection{In Vivo Functionalization Approaches}

This section addresses two different approaches: one based on the use of genetic engineering and synthetic biology tools to modify the biosynthetic machinery, thus varying the resulting polymer (metabolic engineering); the second approach is based on the inherent ability of bacteria to incorporate exogenously provided molecules into the polymer (in situ modifications).

\subsubsection{Metabolic Engineering}

The potential to edit and redirect the cell system using metabolic and genetic engineering tools combined with bioprocess engineering strategies has led to the creation of rationally designed PHAs for targeted applications [29,31]. It is now possible to obtain PHA homopolymers, random and block copolymers, or functional and graft PHA polymers by controlling the carbon flow by manipulating the bacterial PHA synthesis metabolism [171,172]. These strategies have resulted in polymers with enhanced thermal and mechanical properties as well as those presenting new functionalities. For instance, homopolymers obtained through weakened $\beta$-oxidation mutants show improvements in tensile strength, elongation at break, and Young's modulus [67]. Mcl-PHA copolymers showing a higher percentage of long-chain length monomers, such as C12 and C14, exhibit significantly improved thermal and mechanical properties [67]. These polymers showed higher crystallinity, but they behave as thermoplastic elastomers, displaying good tensile strength and desirable elongation at break. They display an increased Young's modulus, a fact that has been shown to improve the processing and molding of the polymer $[67,173]$. $\mathrm{P}(3 \mathrm{HB}-\mathrm{Co}-3 \mathrm{HHx})$ is one of the most promising copolymers as it has shown increased flexibility and high biocompatibility properties, thus rendering it appropriate for biomedical applications such as tissue engineering [174]. In addition, the $\mathrm{P}(3 \mathrm{HB}-\mathrm{co}-4 \mathrm{HB})$ copolymer constitutes a very interesting polymer since its crystallinity and degradability properties 
can be modified by adjusting the $4 \mathrm{HB}$ content [175]. This monomer has been reported to increase the elongation to break by up to $1000 \%$, which increases its applicability in medical fields [69].

Furthermore, the ability of some bacteria to incorporate R-HA-CoA, bearing functional groups from related substrates, gives rise to great monomeric structural diversification by both biosynthetic and postbiosynthetic chemical modifications [31]. Related carbon sources have been used to obtain PHAs containing double or triple bonds [176], monohalogenated [79], aromatic [73,74], thioether [177], thioester [77], cyano, or nitro [76] side groups, among others.

In $P$. putida, the combination of the metabolic engineering strategies and the use of a cofeeding strategy with 6-acetylthiohexanoic acid resulted in a new polymer known as PHACOS, which possesses controllable thioester content [77]. The thioester group confers on the PHACOS polymer a novel antimicrobial functionality; it displays both in vitro and in vivo bactericidal activity against methicillin-resistant $S$. aureus and inhibits biofilm formation [178]. In light of these results, metabolic engineering clearly constitutes a powerful tool for the development of new intrinsically bactericidal polymers.

Metabolic engineering in BC-producing strains remains to be further explored. This is likely due to the lack of fundamental knowledge of these bacteria, as they were sequenced only a few years ago (2010) [23], and to the fact that the genetic toolkits required to enable their modification via synthetic biology approaches have only recently been developed $[179,180]$. Transformation with a unique gene, curdlan synthase, responsible for the synthesis of curdlan, a water-insoluble linear beta-1,3-glucan from Agrobacterium sp. ATCC 31749, into G. xylinus AY201 sufficed for in vivo synthesis of a composite of BC-curdlan, with modified morphology and porosity. As curdlan covered the BC pores, the resulting composite displayed reduced water permeability and greater hydrophobicity than BC [181]. Considering the ability of cellulose synthases (BcsAB) to recognize UDP-Glc-related substrates, another possibility involves the combination of feeding and genetic engineering strategies. For instance, a fluorescent BC was synthetized by feeding K. sucrofermentans with 6-carboxyfluorescein-modified glucose [182]. Additionally, due to the fact that BcsAB is capable of recognizing UDP-N-acetylglucosamine (NAcGlc), a transcription unit comprising 3 genes from Candida albicans, enabling UDP-NAcGlc synthesis, was transferred to G. xylinus 10245 . The resulting strain was able to synthesize a polymer with up to $20 \%$ NAcGlc content when grown in NAcGlc-containing media [44]. Subsequently, the system could be tuned in terms of production by swapping promoters [180]. Furthermore, the resulting polymer was susceptible to lysozyme degradation and, thus, displayed novel biodegradable characteristics in vivo [44] and supported the attachment, proliferation, and differentiation of hMSCs into cartilaginous tissue [183].

These preliminary studies are paving the way towards rational approaches aimed at increasing the mechanical and functional properties of $\mathrm{BC}$; metabolic engineering of $\mathrm{BC}$-producing bacteria can, therefore, be expected to become much more commonplace in the coming years.

PGA properties have also been modified via metabolic engineering, namely, Mw and enantiomeric composition. Different Mw polymers were achieved through the expression of Pgs synthetases from different origins in B. subtilis as a host. For instance, low Mw (29-34 kDa) was produced with B. anthracis pgs, medium Mw (170-660 kDa) with pgs from B. amyloliquefaciens, and high $\mathrm{Mw}$ (up to $8500 \mathrm{kDa}$ ) with its native operon [184]. This is noteworthy because different Mw PGAs would result in different applications. For example, high $\mathrm{Mw}$ is used as an immune-stimulating agent [185], while low Mw PGA is preferred for drug delivery formulations [186]. Furthermore, the combination of the different pgs synthetases with glu racemases provided different stereochemical compositions ranging from 3\% to 60\% D-glu [184]. Another approach was used to tailor the enantiomeric composition of PGA produced in heterologous host C. glutamicum F343 by introducing glu racemase from $B$. subtilis under different expression strength promoters, varying the L-glu content from $36.9 \%$ to $97.1 \%$ [ 40 ]. 


\subsubsection{In Situ Modifications}

A simple, cost-effective method of bacterial biopolymer modification involves the in situ supplementation of the medium with additive chemicals in the culture medium, which can be incorporated directly into the growing polymer chains. This approach is widely reported in the literature for $\mathrm{BC}$ modification, for example, and has been extensively reviewed elsewhere [187]. Indeed, this approach can be harnessed for incorporating bioactive molecules (i.e., antimicrobials) into BC in an economical manner, although there is a need to address certain concerns regarding the cytotoxicity for the producing bacteria, the effects on the already low yields of BC production, as well as the compatibility of the incorporating molecules with the restrictive fermentation conditions of the Komagaetibacter genus. For these reasons, very few of the many antimicrobial molecules have been incorporated by means of this approach.

Butchosa et al. first reported the bactericidal activity of $\mathrm{BC}$ on the incorporation of partially deacetylated chitin nanocrystals (D-ChNCs). D-ChNCs were formed by chitin treatment with $\mathrm{NaOH}$ and subsequently added to an Acetobacter aceti AJ-12368 culture medium. The resulting BC pellicles had only an $8 \%$ content of D-ChNCs due to the toxicity exerted towards the bacterial producer [188]. To overcome the bactericidal effects of CS on $\mathrm{BC}$-producing bacteria, a rotating dynamic culture strategy was employed to produce in situ fabric-embedded CS/BC hydrogel sheets in a horizontal rotating bioreactor, resulting in composites with bacteriostatic activity against Staphylococcus aureus and E. coli [189].

Bioactive glass nanoparticles (NBG) have also been studied as additives to BCproducing media for G. xylinus ATCC 10245. Bioactive glass based on $\mathrm{SiO}_{2}, \mathrm{CaO}$, and $\mathrm{P}_{2} \mathrm{O}_{5}$ was incorporated homogenously into growing $\mathrm{BC}$ chains. The resulting composite, $\mathrm{BC}-\mathrm{NBG}$, presented an enhanced antibacterial activity when compared to NBG, displaying bacteriostatic activity at concentrations as low as $50 \mathrm{mg} \mathrm{mL}^{-1}$ for the Gram-negative pathogens E. coli, P. aeruginosa, Proteus vulgaris, and Kleibsella pneumonia and the Grampositive bacteria B. subtilis and S. aureus. Moreover, the NBG additive also enhanced BC productivity by 2.3 times as a result of its buffering capacity, which counteracted inhibition by gluconic acid conversion from glucose [190].

An economical procedure was performed by Chen et al., who took advantage of the naturally occurring antibacterial molecules present in plants. By supplementing BCproducing medium with mulberry leaf hydrolysate, they achieved incorporation of its flavonoids, mainly rutin and quercetin, into BC pellicles. Although the $\mathrm{BC}$ synthesis inhibitors present in the extract reduced the $B C$ yield, the resulting pellicle presented bacteriostatic activity against both Gram-negative (E. coli) and Gram-positive bacteria (S. aureus) [191].

Conversely, intracellular polymers (i.e., PHAs) are more difficult to chemically functionalize in situ during production. One example consists of PHB-AgNPs composites formed in vivo. Upon addition of silver nitrate in cultures of $C$. necator grown for $24 \mathrm{~h}$, this bacterium showed an inherent capacity to reduce it to AgNPs. Furthermore, the resulting AgNPs were dispersed among the PHB granules, which upon extraction and formulation into films, displayed antibacterial activity against Listeria monocytogenes and Salmonella enterica [192].

\subsection{In Vitro Functionalization Approaches}

This section addresses two different approaches: one based on the ability to functionalize biopolymers with peptides using tags derived from their microbial metabolic machinery (peptide affinity-based functionalization); a second approach employs polymer chemistry to diversify the chemical structure of the material driven by the target application (chemical modifications).

\subsubsection{Peptide Affinity-Based Functionalization}

PHAs have been proposed as a material that can easily be functionalized by tagging granule-associated proteins (GAPs). The strong binding of GAPs both to in vivo and 
in vitro granule beads, whether natural or artificial, and the fact that they can be costeffectively produced from various microorganisms by large-scale fermentation have all boosted the emergence of many biotechnological and medical applications. By fusing the gene coding for a protein of interest to any GAP, the PHA beads can be functionalized to display new tailor-made properties [178]. Phasins, PHA synthases, and depolymerases (or their PHA-binding domains) have been used as affinity tags for the display of heterologous proteins on PHA both in vivo and in vitro. The advantage of the in vivo procedure comes from the fact that both the PHA biosynthesis and the protein expression and immobilization take place simultaneously, reducing time and costs. Moreover, the in vivo PHA biosynthesis provides the cytoplasm a more oxidizing environment that favors native-like disulfide bond formation, and, in fact, the recombinant human tissue plasminogen activator, containing nine disulfide bonds, can be properly folded purified from the supernatant fraction after the in vivo immobilization on the granule, making use of $\mathrm{PhaP} 1_{\text {Reu }}$ as an affinity tag and a thrombin cleavage site as a linker [193]. However, an in vitro approach in which both fusion proteins and polymers are separately purified and subsequently bound ensures purity standards and tight control of the protein load, which is more suitable to biomedical applications. In any case, these approaches, widely reported for PHA and, to a lesser extent, for BC, still remain largely unexplored for PGA functionalization.

Functionalized PHAs are increasingly being used as drug-delivery systems. The human $\alpha 1$-acid glycoprotein [194], the epidermal growth factor receptor-targeting peptide [195], the RGD4C peptide [196] tagged to PHA nanoparticles by means of the phasin PhaP from Aeromonas hyrophila, or the synthase PhaC from Ralstonia eutropha have all been tested as tumor-targeting carriers, whereas the mannose receptor of macrophages immobilized to the PHA nanobeads by PhaP has been proven to specifically bind macrophages [194]

PHA granules with a tag-based oriented display of antigen or antibodies have been successfully generated and can be employed for research or clinical diagnostic purposes. The PHA-binding domain of PhaZ depolymerase from Alcaligenes faecalis $\left(\mathrm{SBD}_{\mathrm{Afa}}\right)$ was fused to a severe acute respiratory syndrome coronavirus envelope protein and used in subsequent immunoassays for diagnosis [197]. Similarly, the same binding domain was fused to streptavidin and used to immobilize pathogen-biotin-labeled DNA probes on PHB beads that were formulated into a microarray capable of detecting the DNA of specific pathogens even in the presence of other microorganisms [198]. In another study, mouse interleukin-2 (IL2) and the myelin oligodendrocyte glycoprotein (MOG), fused to PhaP and attached to the polyester beads, were employed for the specific and sensitive detection of antigen-specific serum antibodies by fluorescence-activated cell-sorting (FACS) technology [199]. On the other hand, the immune-dominant bovine tuberculosis antigens ESAT6, CFP10, Rv3615c, and Rv3020c were translationally fused to the PHA synthase from P. aeruginosa, succeeding in the formation of antigen-displaying polyester beads that demonstrated to be a cost-effective tool for skin testing detection of bovine tuberculosis [200].

For tissue regeneration applications, PHA's lack of recognition sites for cell attachment needs to be compensated by immobilizing biomolecules, such as growth factors, therapeutic proteins, ECM proteins, or the cell-binding domains of ECM. Tailoring the properties of the material surface enables improved biocompatibility and controlled cell adhesion. For this purpose, the phasin PhaP from Aeromonas hydrophila has been genetically fused to ubiquitous Arg-Gly-Asp (RGD) or the laminin-derived Ile-Lys-Val-Ala-Val (IKVAV) motifs, purified and bound to artificial particles in vitro. These fusion proteins are capable of being recognized by the transmembrane integrins, which are then activated, inducing and promoting cell adhesion/proliferation. This strategy has been developed for implant tissue engineering in mouse fibroblasts [201], human bone marrow mesenchymal stem cells [202], and neural stem cells [203].

Finally, affinity-tagged PHA beads have been employed as vaccine delivery systems based on antigens displayed on bioengineered bacterial polyesters, which have been proven to stimulate cellular immune responses both for bacterial $[13,204]$ or viral $[205,206]$ infections. Moreover, they have been applied as antibacterial surfaces using the PhaP tag 
to effectively coat the antimicrobial peptide tachyplesin I (Tac) on a PHBHV polymer as an in vivo skin wound model, accelerating wound healing by efficiently inhibiting the growth of both Gram-negative and Gram-positive bacteria [207].

In the case of $\mathrm{BC}$, a broad family of cellulose-binding domains (CBDs) exists naturally as part of fungal and plant cellulases as well as in scaffolding units of bacterial cellulosomes. They vary in their capacity to bind to crystalline $\mathrm{BC}$, amorphous $\mathrm{BC}$, or both types of polymer. They also vary in the reversibility of the bonding as well as in their specificity, with many tags being able to bind to other types of polysaccharides such as chitin. A detailed revision of CBDs is provided elsewhere [208] or in the carbohydrate-binding domain database.

The use of CBDs has long been widely reported for tagging [209], immobilization of proteins of industrial interest [210], and fiber modification [211], but not to the same extent for the incorporation of biomedical molecules. By fusing the gene coding of a protein of interest to any $\mathrm{CBD}$, cellulosic materials can be functionalized to display bioactive activities.

For tissue engineering applications, $\mathrm{BC}^{\prime} \mathrm{s} 3 \mathrm{D}$ network structure provides the environment to allow cell growth within the matrix. However, cells attach weakly onto bare $\mathrm{BC}$. This can be improved by using adhesion molecules. In this sense, the CBD from the cellulosomal scaffolding protein $\mathrm{A}$ of the bacteria Clostridium thermocellum $\left(\mathrm{CBD}_{\text {ther }}\right)$ has been fused to RGD peptides, purified and immobilized into BC matrices. These fusions have successfully enhanced adhesion/biocompatibility in $B C$ with mouse fibroblast embryo culture [212] and human microvascular endothelial cell proliferation [213], with demonstrated hemocompatibility of the resulting material [214]. Likewise, $\mathrm{CBD}_{\text {ther }}$ was fused to IKVAV peptides, resulting in better adhesion to functionalized BC of both neuronal and mesenchymal cells [215].

Moreover, a relatively unexplored domain involves the antimicrobial coating of $\mathrm{BC}$ via CBD functionalization. A T4 phage lysozyme was fused to the CBD of a scaffolding protein from the cellulosome of Cellulomonas fimi. The resulting antimicrobial fusion protein was attached to commercial cellulose gauzes, which then displayed bactericidal activity against both Gram-positive and Gram-negative bacteria [216]. A shortened CBD motive of only 7 amino acids was fused to a short antimicrobial peptide (12 amino acids), resulting in membranes that displayed up to 4 logarithmic units of reduction against Gram-positive $S$. aureus and 1 logarithmic unit reduction against Gram-negative P. aeruginosa [217].

\subsubsection{Chemical Modifications}

There are many possibilities for chemical functionalization to increase the diversity of bacterial polymers possessing properties tailored to the target applications. Strategies can be based on blending, grafting/crosslinking, and curing. These techniques are generally combined to obtain the final materials, with properties for specific applications $[13,204,218-220]$.

Blending strategies result in materials formed via physical interactions by means of mixing different polymers. The process of blending usually involves solvent-casting and melt-compounding methods [221]. In the case of BC, a major drawback is its poor solubility in both polar and nonpolar solvents. Previous modifications of BC, such as acetylation or grafting with polar molecules, can enhance its solubility. Thus, very few examples of BC blending can be found in the literature.

Grafting is a method for covalently binding molecules (or other polymers) to a polymer chain to produce modified (or newly conferred) physicochemical or functional properties in the resulting material. Different methods have been developed to obtain graft copolymers derived from bacterial biopolymers; some of these involve chemical, photochemical, radiation, plasma-induced, and enzymatic grafting techniques. Surface properties can also be modified with the use of chemical reactions. In this sense, the abundance of hydroxyl groups on the surface of $\mathrm{BC}$ makes them susceptible to modification, transforming them into carboxylic acid, amine, aldehyde, or thiol groups. Further modification of these groups could lead to the grafting of a wide range of molecules such as proteins, polymers, metal nanoparticles, and antibiotics [222]. Plasma treatment is a grafting technique consisting 
of the dispersal of an ionized gas; the procedure introduces functional groups onto the surfaces due to the high reactivity of the ions and electrons. Interestingly, it only modifies the surface layer without affecting the bulk properties of the polymer [204].

Also highly relevant is chemical crosslinking, which consists of the covalent bonding of monomers onto a polymer chain in the presence of crosslinkers, forming tridimensional networks [223]. This strategy has been explored to obtain a polymeric matrix with enhanced properties aimed at conferring to it antimicrobial activity by adding another component in a further step.

Curing is a technique in which an oligomer polymerizes to form a coating that adheres to the substrate by physical forces. The most popular curing method for polymer composites is thermal curing. It is widely used for preparing biocomposites due to its application in industry, including the automotive, construction, and furniture sectors. These biopolymers are reinforced with other compounds such as resins [224] or zirconia [225] in order to provide better mechanical properties. However, they are not commonly used to obtain materials for biomedical applications.

Finally, the preparation of composites based on bacterial biopolymers involves techniques such as polymer blending, crosslinking polymer matrices, and branched copolymers, along with the incorporation of additives such as plasticizers, reinforcement by inorganic fillers, binary salt systems, and impregnation with ionic liquid doping of nanomaterials [226]. These functionalized composites can incorporate antibiotics, organic or inorganic compounds, antimicrobial peptides, or cationic agents to obtain antimicrobial activity $[13,204]$. Table 5 provides revised information on chemical modifications of bacterial biopolymers.

Table 5. Examples of chemical modifications of bacterial polymers.

\begin{tabular}{|c|c|c|c|}
\hline & Blend Composition & Key Features & Ref. \\
\hline \multirow{6}{*}{ PHA } & $\mathrm{P}(3 \mathrm{HB}) / \mathrm{P}(3 \mathrm{HB}-c o-3 \mathrm{HHx})$ & $\begin{array}{l}\text { Better cell biocompatibility on blend polymer scaffolds of } \\
\text { PHBHHx/PHB. PHB crystallization degree decreased with } \\
\text { increasing PHBHHx content. }\end{array}$ & $\begin{array}{l}{[227,} \\
228]\end{array}$ \\
\hline & $\mathrm{P}(3 \mathrm{HB}) / \mathrm{P}(3 \mathrm{HO}-c o-3 \mathrm{HHx})$ & $\begin{array}{l}\text { Higher Young's modulus, tensile strength, thermal stability, } \\
\text { tailorable biodegradability, and improved biocompatibility with } \\
\text { HMEC-1 cells when compared with } \mathrm{P}(3 \mathrm{HO}-\mathrm{co}-3 \mathrm{HHx}) \text { films. }\end{array}$ & [229] \\
\hline & $\mathrm{P}(3 \mathrm{HB}) /$ lignin & $\begin{array}{l}\text { Lignin contents } \leq 30 \mathrm{wt} \% \text { reduce the crystallinity of PHB. At } \\
\text { higher lignin contents, the blends have higher dynamic storage } \\
\text { and loss modulus than pure PHB. }\end{array}$ & [230] \\
\hline & $\mathrm{P}(3 \mathrm{HB}-\mathrm{co}-3 \mathrm{HV}) / \mathrm{PLA}$ & $\begin{array}{l}\text { Blends were immiscible for all compositions. Improved thermal } \\
\text { stability and significant ductile plastic deformation. }\end{array}$ & [231] \\
\hline & mcl-PHA/PLA & $\begin{array}{l}\text { Improved elongation at break, lower crystallization, and higher } \\
\text { biocompatibility. }\end{array}$ & [232] \\
\hline & $\begin{array}{l}\mathrm{P}(3 \mathrm{HB}-\mathrm{co}- \\
3 \mathrm{HHx}) / \text { polycaprolactone } \\
(\mathrm{PCL})\end{array}$ & $\begin{array}{l}\text { Improved degradation and mechanical and biocompatibility } \\
\text { properties. }\end{array}$ & [233] \\
\hline \multirow{2}{*}{$\mathrm{BC}$} & $\begin{array}{l}\text { BC/poly(methylmethacrylate) } \\
\text { (PMMA) }\end{array}$ & Improved mechanical properties and biocompatibility. & [234] \\
\hline & $\begin{array}{l}\text { BC/antimicrobial PHA } \\
\text { (PHACOS) }\end{array}$ & Antibacterial activity against $S$. aureus. & [235] \\
\hline \multirow{3}{*}{$\gamma$-PGA } & $\gamma$-PGA/chitosan (CS) & $\begin{array}{l}\text { Improved hydrophilic, cytocompatibility, and mechanical } \\
\text { properties. }\end{array}$ & [236] \\
\hline & PGA/gelatin & $\begin{array}{l}\text { Gelatin stabilizes PGA molecules. Improved mechanical } \\
\text { properties and biocompatibility with vascular cells. }\end{array}$ & [237] \\
\hline & PCL/PGA & $\begin{array}{l}\text { Hydrophilicity and water uptake of the nanofibrous scaffolds } \\
\text { increased with PGA content. }\end{array}$ & [238] \\
\hline
\end{tabular}


Table 5. Cont.

\begin{tabular}{|c|c|c|c|}
\hline Polymer & Grafting Molecule & Key Features & Ref. \\
\hline $\mathrm{P}(3 \mathrm{HO}-c o-3 \mathrm{HU})$ & Thiolation with Jeffamine ${ }^{\circledR}$ & $\begin{array}{l}\text { Water-soluble amphiphilic copolymers with thermoresponsive } \\
\text { behavior. }\end{array}$ & [239] \\
\hline unsaturated PHA & Epoxidation & $\begin{array}{l}\text { Epoxidation sped up the crosslinking reaction and resulted in a } \\
\text { strong, tear-resistant film with increased tensile strength and } \\
\text { Young's modulus. }\end{array}$ & [240] \\
\hline $\mathrm{P}(3 \mathrm{HO}), \mathrm{P}(3 \mathrm{HB})$ & Chlorination & $\begin{array}{l}\text { Increased } T g \text { and } T m \text {, while the same procedure on } \mathrm{P}(3 \mathrm{HB}) \\
\text { translates to a decrease in } T m \text { and increase in } T g \text {. Modulation of } \\
\text { the hydrophobicity of the polymers. }\end{array}$ & [78] \\
\hline $\mathrm{P}(3 \mathrm{HB})$ & Alkali treatment with $\mathrm{NaOH}$ & $\begin{array}{l}\text { Treatment of } \mathrm{P}(3 \mathrm{HB}) \text { surfaces with } \mathrm{NaOH} \text { enhanced } \\
\text { proliferation of human osteoblasts and inhibited S. aureus } \\
\text { growth }\end{array}$ & [241] \\
\hline PHB & PVA & $\begin{array}{l}\text { Decreased crystallinity and enhanced biodegradability of the } \\
\text { final polymer. }\end{array}$ & [242] \\
\hline unsaturated PHA & PNIPAm oligomers & $\begin{array}{l}\text { Improved surface hydrophilicity and thermoresponsive } \\
\text { properties. Good biocompatibility for cell growth and } \\
\text { thermoresponsive cell detachment ability. }\end{array}$ & [243] \\
\hline PHA & $\begin{array}{l}\text { Fibronectin active fragment } \\
\text { (GRGDS peptide) }\end{array}$ & Exhibited cell adhesiveness and improved biocompatibility. & [244] \\
\hline $\mathrm{P}(3 \mathrm{HB}-c o-3 \mathrm{HV})$ & RGD-containing peptides & $\begin{array}{l}\text { Increased hydrophilicity of the surface of the film and } \\
\text { improved cellular compatibility. }\end{array}$ & [245] \\
\hline $\mathrm{P}(3 \mathrm{HO})$ & Vinyl imidazole & $\begin{array}{l}\text { Increased hydrophilicity and biocompatibility and showed } \\
\text { antibacterial activity against E. coli and S. aureus. }\end{array}$ & [246] \\
\hline $\mathrm{P}(3 \mathrm{HB})$ & Different amino compounds & $\begin{array}{l}\text { Amino-PHB polymers showed antibacterial, antioxidant, and } \\
\text { anticancer activities. PHB-ethylendiamine displayed better } \\
\text { growth-inhibitory antibacterial activity against } S \text {. aureus, K. } \\
\text { pneumoniae, P. aeruginosa, and E. coli. PHB-piperazine showed a } \\
\text { potent anticancer effect against in vivo Ehrlich ascitic } \\
\text { carcinoma-bearing mice. }\end{array}$ & [247] \\
\hline $\begin{array}{l}\mathrm{P}(3 \mathrm{HB}) \\
\mathrm{P}(3 \mathrm{HB}-\mathrm{co}-3 \mathrm{HV})\end{array}$ & CS and CS oligosaccharides & Decreased thermal stability of the chitosan backbone. & [248] \\
\hline $\begin{array}{l}\mathrm{P}(3 \mathrm{HO}) \\
\mathrm{P}(3 \mathrm{HB}-\mathrm{co}-3 \mathrm{HV})\end{array}$ & CS & $\begin{array}{l}\text { Solubilization of chitosan-g-PHA graft depends on grafting } \\
\text { percentage. }\end{array}$ & [249] \\
\hline $\mathrm{P}(3 \mathrm{HB})$ & Ar plasma & $\begin{array}{l}\text { Increased surface polarity; improved cell adhesion, } \\
\text { proliferation, and spreading homogeneity on the PHB surface }\end{array}$ & [250] \\
\hline $\mathrm{P}(3 \mathrm{HB})$ & $\mathrm{O}_{2}$ plasma & $\begin{array}{l}\text { Enhanced hydrophilicity. Ability to directly immobilize T4 } \\
\text { bacteriophages, resulting in an antimicrobial material against } E \text {. } \\
\text { coli. }\end{array}$ & [251] \\
\hline
\end{tabular}


Table 5. Cont.

\begin{tabular}{|c|c|c|c|}
\hline Polymer & Grafting Molecule & Key Features & Ref. \\
\hline \multirow{9}{*}{$\mathrm{BC}$} & Aminoalkyl groups & $\begin{array}{l}\text { Improved mechanical and thermal properties. Antimicrobial } \\
\text { properties against } S \text {. aureus and E. coli and was nontoxic to } \\
\text { human adipose-derived mesenchymal stem cells. }\end{array}$ & [252] \\
\hline & $\begin{array}{l}\text { Oligo peptides, } \\
\text { glycyl-L-glutamine or } \\
\text { glycyl-glycyl-glycine }\end{array}$ & $\begin{array}{l}\text { Enhanced its interfacial wettability, boosted mineralization } \\
\text { induction, and improved affinity between polymeric and } \\
\text { mineral phases. }\end{array}$ & [253] \\
\hline & $\begin{array}{l}\text { RGDC peptides and } \\
\text { gentamicin }\end{array}$ & $\begin{array}{l}\text { Growth inhibition of } S . \text { mutans and promoted fibroblast } \\
\text { adhesion and proliferation. }\end{array}$ & [254] \\
\hline & Amoxicillin (AM) & $\begin{array}{l}\text { Good porosity and swelling behaviors. Antibacterial activities } \\
\text { against E. coli, C. albicans, and S. aureus and nontoxic to HEK } 293 \\
\text { cells }\end{array}$ & [255] \\
\hline & $\mathrm{AM}$ & $\begin{array}{l}\text { Good stability with a slight reduction in swelling capabilities. } \\
\mathrm{pH} \text { responsiveness with an increase in drug swelling and } \\
\text { release at higher } \mathrm{pH} \text {. }\end{array}$ & [256] \\
\hline & CS & $\begin{array}{l}\text { Better uniformity of nanosized fibrils, with better acid and } \\
\text { temperature stability. Enhanced BC dispersion. }\end{array}$ & [257] \\
\hline & $\mathrm{N}_{2}$ plasma & $\begin{array}{l}\text { Increased porosity and the number of functional groups on the } \\
\text { surface of BC, which improved the cell adhesion. }\end{array}$ & [258] \\
\hline & $\mathrm{O}_{2}$ and $\mathrm{N}_{2}$ plasmas & $\begin{array}{l}\text { Increased surface hydrophilicity due to the incorporation of } \\
\text { carbon-oxygen and amide and amino groups. }\end{array}$ & [259] \\
\hline & $\mathrm{CF}_{4}$ plasma & $\begin{array}{l}\text { Surface presented hydrophobic properties and potential to } \\
\text { promote cell adhesion and proliferation due to greater } \\
\text { adsorption of proteins on the BC surface. }\end{array}$ & [259] \\
\hline \multirow{4}{*}{ PGA } & PCL & $\begin{array}{l}\text { Improved shear elasticity and compressive strength. } \\
\text { Provided effective protection for femoral condyle and tibial } \\
\text { plateau cartilage when applied in a rabbit model and } \\
\text { regenerated a meniscus-like tissue. }\end{array}$ & [260] \\
\hline & Benzyl groups & $\begin{array}{l}\text { Novel electrospun biopolymer exhibited rapid shrinkage upon } \\
\text { induction by heat or a series of solvents. }\end{array}$ & [261] \\
\hline & $\begin{array}{l}\text { Phenylalanine (Phe) or leucine } \\
\text { (Leu) }\end{array}$ & $\begin{array}{l}\text { Production of bionanoparticles derived from } \gamma \text {-PGA and } \\
\text { phenylalanine ethyl ester, with excellent water dispersibility, } \\
200 \text { nm diameters, and surface chemical functionality of } \\
\text { carboxyl groups, }\end{array}$ & [262] \\
\hline & $\beta$-sheet peptides & $\begin{array}{l}\text { Hydrogel stiffness can be controlled by changing the } \beta \text {-sheet } \\
\text { peptide graft density, the bulk hydrogel concentration, and the } \\
\text { ratio of covalently coupled and free peptides. Additional } \\
\text { functionality can be incorporated into this self-healing hybrid } \\
\text { hydrogel. }\end{array}$ & [263] \\
\hline Material & Cross-Linking Agent & Key Features & Ref. \\
\hline $\begin{array}{l}\text { BC } \\
\text { BC-CS membranes }\end{array}$ & Tripolyphosphate (TPP) & $\begin{array}{l}\text { Optimum water vapor permeability. BC-CS exhibited local and } \\
\text { peripheral inhibition of bacterial growth. The presence of } \\
\text { ciprofloxacin effectively produced a stronger inhibition effect } \\
\text { on both tested bacteria, P. aeruginosa and S. aureus }\end{array}$ & [264] \\
\hline BC/CS blends & Glutaraldehyde & $\begin{array}{l}\text { Showed flexibility, high thermal stability, and high mechanical } \\
\text { properties. Showed antibacterial properties against tested } \\
\text { Gram-positive and Gram-negative bacteria. }\end{array}$ & [265] \\
\hline
\end{tabular}


Table 5. Cont.

\begin{tabular}{|c|c|c|c|}
\hline Material & Cross-Linking Agent & Key Features & Ref. \\
\hline $\begin{array}{l}\text { Functionalization } \\
\text { of BC with } \\
\varepsilon \text {-poly-L-Lysine } \\
(\varepsilon-\text { PLL) }\end{array}$ & Carbodiimide chemistry & $\begin{array}{l}\text { Preserved the good structural and mechanical properties of BC. } \\
\text { Inhibited growth of } S \text {. epidermidis on the membranes and was } \\
\text { cytocompatible with human fibroblasts. }\end{array}$ & [266] \\
\hline $\begin{array}{l}\text { Unsaturated } \\
\text { copolyester } \\
\text { (PHBU) }\end{array}$ & Thiol-ene click chemistry & $\begin{array}{l}\text { Enhanced tensile strength without affecting cytotoxicity and } \\
\text { biocompatibility towards human mesenchymal stem cells. }\end{array}$ & [267] \\
\hline $\begin{array}{l}\text { Unsaturated PHA } \\
\text { copolymer } \\
\text { poly[(R)-3- } \\
\text { hydroxyundeca- } \\
\text { noate-co- }(R)-3- \\
\text { hydroxy-10- } \\
\text { undecenoate] } \\
\text { P(HU10U) }\end{array}$ & $\begin{array}{l}\text { Polyethylene glycol dithiol } \\
\text { (PDT) }\end{array}$ & $\begin{array}{l}\text { Swelling behavior in different solvents; mechanical and } \\
\text { morphological properties could be tuned by varying the ratio of } \\
\text { P(HU10U) to PDT. Good biocompatibility. }\end{array}$ & [268] \\
\hline $\begin{array}{l}\text { PGA-conjugated } \\
\text { cysteamine } \\
\text { (PGA-SH) and } \\
\text { methacrylate-PGA } \\
\text { (PGA-GMA) }\end{array}$ & Michael-addition reactions & $\begin{array}{l}\text { Mechanical properties, porous structure, swelling, and } \\
\text { degradation process of the hydrogels could be controlled by } \\
\text { adjusting modified PGA polymer component. Exhibited good } \\
\text { biocompatibility and high stability. Promoted chondrogenesis } \\
\text { of loaded BMSCs and facilitated cartilage reconstruction in the } \\
\text { defected area in a rabbit auricular cartilage defect model. }\end{array}$ & [157] \\
\hline Hydrogels of PGA & $\begin{array}{l}\mathrm{N}, \mathrm{N}, \mathrm{N} \text {-trimethyl-3-[(2- } \\
\text { methylacryloyl)amino]propan- } \\
\text { 1-aminium } \\
\text { (METH) }\end{array}$ & $\begin{array}{l}\text { Maintained a stable form during the nine weeks of the study. } \\
\text { Useful for preparing particles. }\end{array}$ & [269] \\
\hline Cured Material & & Key Features & Ref. \\
\hline \multicolumn{2}{|c|}{ BC crosslinked with citric acid } & $\begin{array}{l}\text { Improved rehydration capacity; showed higher porosity, } \\
\text { wettability, and water swelling. }\end{array}$ & [270] \\
\hline \multicolumn{2}{|c|}{$\begin{array}{l}\text { PHA combined with segments of polyurethane } \\
\text { (PHP), telechelic-hydroxylated } \\
\text { polyhydroxyalkanoate (PHA-diols), and } \\
\text { polyethylene glycol (PEG) }\end{array}$} & $\begin{array}{l}\text { Good shape-memory effect (SME) and rapid recovery. Possess } \\
\text { thermo- and water-responsive properties, properties of } \\
\text { triggering shape-morphing, enabling self-folding and } \\
\text { self-expansion of shapes into three-dimensional (3D) scaffolds. }\end{array}$ & [271] \\
\hline \multicolumn{2}{|c|}{$\begin{array}{l}\text { Light cured methacrylated PGA nanoparticle-created } \\
\text { hydrogel system (PGA nanogel) }\end{array}$} & $\begin{array}{l}\text { Good swelling and mechanical properties. Good antibiotic } \\
\text { release behavior. Good biocompatibility. }\end{array}$ & [272] \\
\hline
\end{tabular}

\section{Regulatory Aspects and Transferability into Clinics}

The field of nanomedicine faces several challenges for regulatory approval as a result of the unpredictability of nanobiomaterials with biological systems, which has been assessed so far in a case-by-case manner. The current lack of guidelines for nanomedicine research has recently been filled by the new Safe by Design (SbD) approach developed within EU nanomedicine projects. It is worth noting that the development of polymeric nanomaterials designed for nanobiomedicine should include a Safety by Design (SbD) evaluation, which is based on the identification and reduction of the risks regarding human health and environmental safety. A proposal of normative and regulatory requirements as well as the methodological approaches of $\mathrm{SbD}$ for nanobiomaterial development are described in the framework of the GoNanoBioMaT project from the Swiss Federal Laboratories for Materials Science and Technology (EMPA) [273,274].

However, it is remarkable that very few products have reached the commercial level despite the years of research and the ever-growing number of patents regarding bacterial polymers for biomedical applications.

For instance, the first company to obtain FDA approval for PHA-based devices was the Thepha Inc company (USA). It obtained its approval for $\mathrm{P}(4 \mathrm{HB})$-based sutures in 
2004. Since then, they have developed other approved devices such as surgical films and composite meshes. Other commercial medical products based on PHA include the ElastoPHB biopolymer membrane system for repairing soft and cartilage tissue defects (BIOMIR Service JSC, Moscow, Russia).

Likewise, despite the ideal properties of $\mathrm{BC}$ in the field of wound healing and the generally recognized as safe (GRAS) status of BC producer strains, only a few commercial dressings have been approved by regulatory agencies and commercialized. Their main indications are as skin substitutes for burn and ulcer patients. Some examples are Biofill ${ }^{\circledR}$ and BioProcess ${ }^{\circledR}$, with antibacterial properties (Biofill, Brazil); Xcell ${ }^{\circledR}$ and Xcell antimicrobial from Xylos (Xylos Corporation, PA, USA), which obtained the FDA approval in 2003; antimicrobial Ag-based Nanoderm ${ }^{\circledR}$ (Axcelon Biopolymers Corp, Canada); Superabsrob X + PHMB, a drug delivery system of antiseptic PHMB (Activa Healthcare, L\&R Company, UK); EpiProtect ${ }^{\circledR}$ (S2Medical AB, Sweden); Membracell (Vuelo Pharma, Brazil); and Nanoskin (Innovatec, Brazil). Other applications with commercial use include dental implants (Gengiflex ${ }^{\circledR}$ by Biofill).

In the case of PGA, the current market situation is focused on PGA production as an additive for personal care and cosmetic uses (i.e., SpecKare PGA by Spec Chem Industry, Nanjing, China; PGA by XI'AN Neo Biotech Ltd., Nanjing, China). For instance, in 2019, Cult Beauty (UK) launched a serum with PGA as the main active compound as a moisturizing agent. This lack of biomedical-based PGA products in the market, to the best of our knowledge, reflects the late development of PGA research regarding the other two polymers, as has been highlighted throughout this review.

\section{Conclusions}

This review provides insight toward the recent advances in bacterial biopolymer production by upcycling bioprocesses, their main uses in the biomedical field as nanomaterials, and, finally, the different approaches to structurally diversify these polymers to further expand their applications. Despite great advances in the design of cell factories and bioprocesses to enhance biopolymer production, challenges remain to gain economic competitiveness. Upcycling of industrial and municipal wastes is indeed a necessary approach to increase economic profitability while reducing the global environmental impact. The interest in bacterial polymers has grown exponentially in biomedical research, mainly in three domains: drug nanocarriers, implantable material coatings, and tissue-regeneration scaffolds or membranes due to their biocompatibility, biodegradability, and mechanical properties. Bacteria are able to produce a considerable diversity of polymer structures with a plethora of backbones, such as polysaccharides (e.g., BC), polyesters (e.g., PHA), and polyamides (e.g., PGA), the chemical structures and mechanical properties of which depend on the metabolic background of the cell biocatalyst and the feedstock and fermentation conditions. Here, we provide examples of BC, PHA, and PGA applications as nanocarriers for drug delivery systems and in tissue engineering, wound healing, vascular grafts, cardiac valves and vessel stents, sutures, and biological glues. Moreover, the natural diversity of bacterial polymers can be further broadened by means of metabolic engineering, in situ modifications, peptide functionalization, and chemical modifications, thus enhancing their properties or conferring new functionalities. Synergistic and multidisciplinary strategies based on cutting-edge technologies, such as synthetic and systems biology, combined with advanced materials technology, including blending, grafting/crosslinking, and curing, provide pathways for enhancing the structural and functional complexity of these biopolymers, thereby expanding the catalog of available biomaterials beyond that which exists in nature, as well as extending their potential applications as nanomaterials in the biomedical sector.

Author Contributions: Conceptualization, F.G.B. and M.A.P.; investigation, F.G.B., N.H., V.R.-B., A.M., B.M., J.M.S. and A.M.H.-A.; writing-original draft preparation, F.G.B., N.H., V.R.-B., A.M., B.M., J.M.S., A.M.H.-A. and M.A.P.; writing-review and editing, F.G.B. and M.A.P.; supervision, A.M.H.-A. and M.A.P.; funding acquisition, M.A.P. All authors have read and agreed to the published version of the manuscript. 
Funding: The authors thank the Community of Madrid [P2018/NMT4389], the Spanish Ministry of Science, Innovation, and Universities [BiO2017-8344-8-R, PID2019-105126RB-I00], and the European Union's Horizon 2020 Research and Innovation Programme [grant agreement no 870294 (Mix-Up)] for the financial support of this project. Francisco Blanco is the recipient of a predoctoral grant from the State Program for the Promotion of Talent and Its Employability in R\&D\&I (PRE-2018-083859) from the Spanish Ministry of Science and Innovation.

Informed Consent Statement: Not applicable.

Data Availability Statement: Not applicable.

Acknowledgments: We acknowledge María Rosa Aguilar de Armas from the Polymer Science and Technology Institute (ICTP-CSIC) for the interesting discussions.

Conflicts of Interest: The authors declare no conflict of interest.

\section{References}

1. Godfray, H.C.J.; Beddington, J.R.; Crute, I.R.; Haddad, L.; Lawrence, D.; Muir, J.F.; Pretty, J.; Robinson, S.; Thomas, S.M.; Toulmin, C. Food Security: The Challenge of Feeding 9 Billion People. Science 2010, 327, 812-818. [CrossRef] [PubMed]

2. Aguilar, A.; Twardowski, T.; Wohlgemuth, R. Bioeconomy for Sustainable Development. Biotechnol. J. 2019, 14, 1800638. [CrossRef] [PubMed]

3. Yadav, P.; Yadav, H.; Shah, V.G.; Shah, G.; Dhaka, G. Biomedical Biopolymers, Their Origin and Evolution in Biomedical Sciences: A Systematic Review. J. Clin. Diagn. Res. JCDR 2015, 9, ZE21-ZE25. [CrossRef]

4. Dinjaski, N.; Kaplan, D.L. Recombinant Protein Blends: Silk beyond Natural Design. Curr. Opin. Biotechnol. 2016, 39, 1-7. [CrossRef] [PubMed]

5. Moradali, M.F.; Rehm, B.H.A. Bacterial Biopolymers: From Pathogenesis to Advanced Materials. Nat. Rev. Microbiol. 2020, 18, 195-210. [CrossRef] [PubMed]

6. Yau, A.; Lee, J.; Chen, Y. Nanomaterials for Protein Delivery in Anticancer Applications. Pharmaceutics 2021, 13, 155. [CrossRef] [PubMed]

7. Grigoletto, A.; Tedeschini, T.; Canato, E.; Pasut, G. The Evolution of Polymer Conjugation and Drug Targeting for the Delivery of Proteins and Bioactive Molecules. WIREs Nanomed. Nanobiotechnol. 2020, e1689. [CrossRef]

8. Kim, S.; Jung, U.T.; Kim, S.-K.; Lee, J.-H.; Choi, H.S.; Kim, C.-S.; Jeong, M.Y. Nanostructured Multifunctional Surface with Antireflective and Antimicrobial Characteristics. ACS Appl. Mater. Interfaces 2015, 7, 326-331. [CrossRef]

9. Qiu, H.; Si, Z.; Luo, Y.; Feng, P.; Wu, X.; Hou, W.; Zhu, Y.; Chan-Park, M.B.; Xu, L.; Huang, D. The Mechanisms and the Applications of Antibacterial Polymers in Surface Modification on Medical Devices. Front. Bioeng. Biotechnol. 2020, 8, 910. [CrossRef]

10. Elena, P.; Miri, K. Formation of Contact Active Antimicrobial Surfaces by Covalent Grafting of Quaternary Ammonium Compounds. Colloids Surf. B Biointerfaces 2018, 169, 195-205. [CrossRef]

11. Blackman, L.D.; Qu, Y.; Cass, P.; Locock, K.E.S. Approaches for the Inhibition and Elimination of Microbial Biofilms Using Macromolecular Agents. Chem. Soc. Rev. 2021, 50, 1587-1616. [CrossRef]

12. Tran, H.M.; Tran, H.; Booth, M.A.; Fox, K.E.; Nguyen, T.H.; Tran, N.; Tran, P.A. Nanomaterials for Treating Bacterial Biofilms on Implantable Medical Devices. Nanomaterials 2020, 10, 2253. [CrossRef] [PubMed]

13. Sulaeva, I.; Henniges, U.; Rosenau, T.; Potthast, A. Bacterial Cellulose as a Material for Wound Treatment: Properties and Modifications. A Review. Biotechnol. Adv. 2015, 33, 1547-1571. [CrossRef]

14. Castro, C.; Cleenwerck, I.; Trček, J.; Zuluaga, R.; De Vos, P.; Caro, G.; Aguirre, R.; Putaux, J.-L.; Gañán, P. Gluconacetobacter medellinensis Sp. Nov., Cellulose- and Non-Cellulose-Producing Acetic Acid Bacteria Isolated from Vinegar. Int. J. Syst. Evol. Microbiol. 2013, 63, 1119-1125. [CrossRef]

15. Morikawa, M.; Kagihiro, S.; Haruki, M.; Takano, K.; Branda, S.; Kolter, R.; Kanaya, S. Biofilm Formation by a Bacillus Subtilis Strain That Produces $\gamma$-Polyglutamate. Microbiology 2006, 152, 2801-2807. [CrossRef] [PubMed]

16. Huang, Y.; Zhu, C.; Yang, J.; Nie, Y.; Chen, C.; Sun, D. Recent Advances in Bacterial Cellulose. Cellulose 2014, 21, 1-30. [CrossRef]

17. Yamada, Y.; Yukphan, P.; Lan Vu, H.T.; Muramatsu, Y.; Ochaikul, D.; Tanasupawat, S.; Nakagawa, Y. Description of Komagataeibacter Gen. Nov., with Proposals of New Combinations (Acetobacteraceae). J. Gen. Appl. Microbiol. 2012, 58, 397-404. [CrossRef]

18. Romling, U.; Galperin, M.Y. Bacterial Cellulose Biosynthesis: Diversity of Operons, Subunits, Products, and Functions. Trends Microbiol. 2015, 23, 545-557. [CrossRef]

19. Jacek, P.; Dourado, F.; Gama, M.; Bielecki, S. Molecular Aspects of Bacterial Nanocellulose Biosynthesis. Microb. Biotechnol. 2019, 12, 633-649. [CrossRef]

20. Ross, P.; Weinhouse, H.; Aloni, Y.; Michaeli, D.; Weinberger-Ohana, P.; Mayer, R.; Braun, S.; de Vroom, E.; van der Marel, G.A.; van Boom, J.H.; et al. Regulation of Cellulose Synthesis in Acetobacter xylinum by Cyclic Diguanylic Acid. Nature 1987, 325, $279-281$. [CrossRef] 
21. Hernández-Arriaga, A.M.; Del Cerro, C.; Urbina, L.; Eceiza, A.; Corcuera, M.A.; Retegi, A.; Auxiliadora Prieto, M. Genome Sequence and Characterization of the Bcs Clusters for the Production of Nanocellulose from the Low PH Resistant Strain Komagataeibacter medellinensis ID13488. Microb. Biotechnol. 2019, 12, 620-632. [CrossRef]

22. Jedrzejczak-Krzepkowska, M.; Kubiak, K.; Ludwicka, K.; Bielecki, S. Chapter 2-Bacterial NanoCellulose Synthesis, Recent Findings. In Bacterial Nanocellulose; Gama, M., Dourado, F., Bielecki, S., Eds.; Elsevier: Amsterdam, The Netherlands, 2016; pp. 19-46; ISBN 978-0-444-63458-0.

23. Ryngajłło, M.; Kubiak, K.; Jędrzejczak-Krzepkowska, M.; Jacek, P.; Bielecki, S. Comparative Genomics of the Komagataeibacter Strains-Efficient Bionanocellulose Producers. Microbiologyopen 2019, 8, e00731. [CrossRef] [PubMed]

24. Velasco-Bedrán, H.; López-Isunza, F. The Unified Metabolism of Gluconacetobacter entanii in Continuous and Batch Processes. Process. Biochem. 2007, 42, 1180-1190. [CrossRef]

25. Jang, W.D.; Kim, T.Y.; Kim, H.U.; Shim, W.Y.; Ryu, J.Y.; Park, J.H.; Lee, S.Y. Genomic and Metabolic Analysis of Komagataeibacter xylinus DSM 2325 Producing Bacterial Cellulose Nanofiber. Biotechnol. Bioeng. 2019. [CrossRef]

26. Gao, L.; Wu, X.; Zhu, C.; Jin, Z.; Wang, W.; Xia, X. Metabolic Engineering to Improve the Biomanufacturing Efficiency of Acetic Acid Bacteria: Advances and Prospects. Crit. Rev. Biotechnol. 2020, 40, 522-538. [CrossRef]

27. Ryngajłło, M.; Jacek, P.; Cielecka, I.; Kalinowska, H.; Bielecki, S. Effect of Ethanol Supplementation on the Transcriptional Landscape of Bionanocellulose Producer Komagataeibacter xylinus E25. Appl. Microbiol. Biotechnol. 2019, 103, 6673-6688. [CrossRef]

28. Mezzina, M.P.; Pettinari, M.J. Phasins, Multifaceted Polyhydroxyalkanoate Granule-Associated Proteins. Appl. Environ. Microbiol. 2016, 82, 5060-5067. [CrossRef]

29. Prieto, A.; Escapa, I.F.; Martinez, V.; Dinjaski, N.; Herencias, C.; de la Pena, F.; Tarazona, N.; Revelles, O. A Holistic View of Polyhydroxyalkanoate Metabolism in Pseudomonas putida. Environ. Microbiol. 2016, 18, 341-357. [CrossRef]

30. Kniewel, R.; Lopez, O.R.; Prieto, M.A. Biogenesis of Medium-Chain-Length Polyhydroxyalkanoates. In Biogenesis of Fatty Acids, Lipids and Membranes; Geiger, O., Ed.; Springer International Publishing: Cham, Switzerland, 2019; pp. 457-481; ISBN 978-3-31950430-8.

31. Mezzina, M.P.; Manoli, M.T.; Prieto, M.A.; Nikel, P.I. Engineering Native and Synthetic Pathways in Pseudomonas putida for the Production of Tailored Polyhydroxyalkanoates. Biotechnol. J. 2020, 2000165. [CrossRef]

32. Wang, Q.; Tappel, R.C.; Zhu, C.; Nomura, C.T. Development of a New Strategy for Production of Medium-Chain-Length Polyhydroxyalkanoates by Recombinant Escherichia coli via Inexpensive Non-Fatty Acid Feedstocks. Appl. Environ. Microbiol. 2012, 78, 519-527. [CrossRef]

33. de Eugenio, L.I.; Escapa, I.F.; Morales, V.; Dinjaski, N.; Galan, B.; Garcia, J.L.; Prieto, M.A. The Turnover of Medium-Chain-Length Polyhydroxyalkanoates in Pseudomonas putida KT2442 and the Fundamental Role of PhaZ Depolymerase for the Metabolic Balance. Environ. Microbiol. 2010, 12, 207-221. [CrossRef] [PubMed]

34. Cao, M.; Feng, J.; Sirisansaneeyakul, S.; Song, C.; Chisti, Y. Genetic and Metabolic Engineering for Microbial Production of Poly- $\gamma$-Glutamic Acid. Biotechnol. Adv. 2018, 36, 1424-1433. [CrossRef] [PubMed]

35. Ashiuchi, M. Microbial Production and Chemical Transformation of Poly- $\gamma$-Glutamate. Microb. Biotechnol. 2013, 6, 664-674. [CrossRef] [PubMed]

36. Ogunleye, A.; Bhat, A.; Irorere, V.U.; Hill, D.; Williams, C.; Radecka, I. Poly- $\gamma$-Glutamic Acid: Production, Properties and Applications. Microbiology 2015, 161, 1-17. [CrossRef]

37. Scoffone, V.; Dondi, D.; Biino, G.; Borghese, G.; Pasini, D.; Galizzi, A.; Calvio, C. Knockout of PgdS and Ggt Genes Improves $\gamma$-PGA Yield in B. Subtilis. Biotechnol. Bioeng. 2013, 110, 2006-2012. [CrossRef]

38. Feng, J.; Quan, Y.; Gu, Y.; Liu, F.; Huang, X.; Shen, H.; Dang, Y.; Cao, M.; Gao, W.; Lu, X.; et al. Enhancing Poly- $\gamma$-Glutamic Acid Production in Bacillus amyloliquefaciens by Introducing the Glutamate Synthesis Features from Corynebacterium glutamicum. Microb. Cell Fact. 2017, 16, 88. [CrossRef]

39. Cao, M.; Geng, W.; Zhang, W.; Sun, J.; Wang, S.; Feng, J.; Zheng, P.; Jiang, A.; Song, C. Engineering of Recombinant Escherichia coli Cells Co-Expressing Poly- $\gamma$-Glutamic Acid ( $\gamma$-PGA) Synthetase and Glutamate Racemase for Differential Yielding of $\gamma$-PGA. Microb. Biotechnol. 2013, 6, 675-684. [CrossRef]

40. Xu, G.; Zha, J.; Cheng, H.; Ibrahim, M.H.A.; Yang, F.; Dalton, H.; Cao, R.; Zhu, Y.; Fang, J.; Chi, K.; et al. Engineering Corynebacterium glutamicum for the de novo Biosynthesis of Tailored Poly- $\gamma$-Glutamic Acid. Metab Eng. 2019, 56, 39-49. [CrossRef]

41. Urushibata, Y.; Tokuyama, S.; Tahara, Y. Characterization of the Bacillus Subtilis YwsC Gene, Involved in Gamma-Polyglutamic Acid Production. J. Bacteriol. 2002, 184, 337-343. [CrossRef]

42. Ohsawa, T.; Tsukahara, K.; Ogura, M. Bacillus subtilis Response Regulator DegU Is a Direct Activator of PgsB Transcription Involved in $\gamma$-Poly-Glutamic Acid Synthesis. Biosci. Biotechnol. Biochem. 2009, 73, 2096-2102. [CrossRef]

43. Feng, J.; Gu, Y.; Quan, Y.; Cao, M.; Gao, W.; Zhang, W.; Wang, S.; Yang, C.; Song, C. Improved Poly- $\gamma$-Glutamic Acid Production in Bacillus amyloliquefaciens by Modular Pathway Engineering. Metab Eng. 2015, 32, 106-115. [CrossRef]

44. Yadav, V.; Paniliatis, B.J.; Shi, H.; Lee, K.; Cebe, P.; Kaplan, D.L. Novel in Vivo-Degradable Cellulose-Chitin Copolymer from Metabolically Engineered Gluconacetobacter xylinus. Appl. Environ. Microbiol. 2010, 76, 6257-6265. [CrossRef]

45. Shrivastav, A.; Kim, H.-Y.; Kim, Y.-R. Advances in the Applications of Polyhydroxyalkanoate Nanoparticles for Novel Drug Delivery System. BioMed Res. Int. 2013, 2013, 581684. [CrossRef]

46. Murakami, S.; Aoki, N.; Matsumura, S. Bio-Based Biodegradable Hydrogels Prepared by Crosslinking of Microbial Poly $(\gamma-$ Glutamic Acid) with L-Lysine in Aqueous Solution. Polym. J. 2011, 43, 414-420. [CrossRef] 
47. Fan, K.; Gonzales, D.; Sevoian, M. Hydrolytic and Enzymatic Degradation of Poly( $\gamma$-Glutamic Acid) Hydrogels and Their Application in Slow-Release Systems for Proteins. J. Environ. Polym. Degrad. 1996, 4, 253-260. [CrossRef]

48. Xu, T.; Zhan, S.; Yi, M.; Chi, B.; Xu, H.; Mao, C. Degradation Performance of Polyglutamic Acid and Its Application of Calcium Supplement. Polym. Adv. Technol. 2018, 29, 1966-1973. [CrossRef]

49. Kumbhar, J.V.; Jadhav, S.H.; Bodas, D.S.; Barhanpurkar-Naik, A.; Wani, M.R.; Paknikar, K.M.; Rajwade, J.M. In Vitro and in Vivo Studies of a Novel Bacterial Cellulose-Based Acellular Bilayer Nanocomposite Scaffold for the Repair of Osteochondral Defects. Int. J. Nanomed. 2017, 12, 6437-6459. [CrossRef]

50. Singh, A.K.; Srivastava, J.K.; Chandel, A.K.; Sharma, L.; Mallick, N.; Singh, S.P. Biomedical Applications of Microbially Engineered Polyhydroxyalkanoates: An Insight into Recent Advances, Bottlenecks, and Solutions. Appl. Microbiol. Biotechnol. 2019, 103, 2007-2032. [CrossRef]

51. Karabasz, A.; Szczepanowicz, K.; Cierniak, A.; Bereta, J.; Bzowska, M. In Vitro Toxicity Studies of Biodegradable, Polyelectrolyte Nanocapsules. Int. J. Nanomed. 2018, 13, 5159-5172. [CrossRef]

52. Karabasz, A.; Szczepanowicz, K.; Cierniak, A.; Mezyk-Kopec, R.; Dyduch, G.; Szczech, M.; Bereta, J.; Bzowska, M. In Vivo Studies on Pharmacokinetics, Toxicity and Immunogenicity of Polyelectrolyte Nanocapsules Functionalized with Two Different Polymers: Poly-L-Glutamic Acid or PEG. Int. J. Nanomed. 2019, 14, 9587-9602. [CrossRef]

53. Discher, D.E.; Janmey, P.; Wang, Y.L. Tissue Cells Feel and Respond to the Stiffness of Their Substrate. Science 2005, 310, 1139-1143. [CrossRef] [PubMed]

54. Gorgieva, S.; Trček, J. Bacterial Cellulose: Production, Modification and Perspectives in Biomedical Applications. Nanomaterials 2019, 9, 1352. [CrossRef] [PubMed]

55. Klemm, D.; Heublein, B.; Fink, H.-P.; Bohn, A. Cellulose: Fascinating Biopolymer and Sustainable Raw Material. Angew. Chem. Int. Ed. 2005, 44, 3358-3393. [CrossRef] [PubMed]

56. Czaja, W.; Krystynowicz, A.; Bielecki, S.; Brown, R.M. Microbial Cellulose-the Natural Power to Heal Wounds. Biomaterials 2006, 27, 145-151. [CrossRef]

57. Pogorelova, N.; Rogachev, E.; Digel, I.; Chernigova, S.; Nardin, D. Bacterial Cellulose Nanocomposites: Morphology and Mechanical Properties. Materials 2020, 13, 2849. [CrossRef]

58. Volova, T.G.; Prudnikova, S.V.; Sukovatyi, A.G.; Shishatskaya, E.I. Production and Properties of Bacterial Cellulose by the Strain Komagataeibacter xylinus B-12068. Appl. Microbiol. Biotechnol. 2018, 102, 7417-7428. [CrossRef]

59. Chen, S.-Q.; Lopez-Sanchez, P.; Wang, D.; Mikkelsen, D.; Gidley, M.J. Mechanical Properties of Bacterial Cellulose Synthesised by Diverse Strains of the Genus Komagataeibacter. Food Hydrocoll. 2018, 81, 87-95. [CrossRef]

60. McKenna, B.A.; Mikkelsen, D.; Wehr, J.B.; Gidley, M.J.; Menzies, N.W. Mechanical and Structural Properties of Native and Alkali-Treated Bacterial Cellulose Produced by Gluconacetobacter xylinus Strain ATCC 53524. Cellulose 2009, 16, $1047-1055$. [CrossRef]

61. Machado, R.T.A.; Gutierrez, J.; Tercjak, A.; Trovatti, E.; Uahib, F.G.M.; Moreno, G.P.; Nascimento, A.P.; Berreta, A.A.; Ribeiro, S.J.L.; Barud, H.S. Komagataeibacter rhaeticus as an Alternative Bacteria for Cellulose Production. Carbohydr. Polym. 2016, 152, 841-849. [CrossRef]

62. Urbina, L.; Hernández-Arriaga, A.M.; Eceiza, A.; Gabilondo, N.; Corcuera, M.A.; Prieto, M.A.; Retegi, A. By-Products of the Cider Production: An Alternative Source of Nutrients to Produce Bacterial Cellulose. Cellulose 2017, 24, 2071-2082. [CrossRef]

63. Andritsou, V.; de Melo, E.M.; Tsouko, E.; Ladakis, D.; Maragkoudaki, S.; Koutinas, A.A.; Matharu, A.S. Synthesis and Characterization of Bacterial Cellulose from Citrus-Based Sustainable Resources. ACS Omega 2018, 3, 10365-10373. [CrossRef]

64. Güzel, M.; Akpınar, Ö. Preparation and Characterization of Bacterial Cellulose Produced from Fruit and Vegetable Peels by Komagataeibacter Hansenii GA2016. Int. J. Biol. Macromol. 2020, 162, 1597-1604. [CrossRef] [PubMed]

65. Rai, R.; Keshavarz, T.; Roether, J.A.; Boccaccini, A.R.; Roy, I. Medium Chain Length Polyhydroxyalkanoates, Promising New Biomedical Materials for the Future. Mater. Sci. Eng. R Rep. 2011, 72, 29-47. [CrossRef]

66. Tortajada, M.; da Silva, L.F.; Prieto, M.A. Second-Generation Functionalized Medium-Chain-Length Polyhydroxyalkanoates: The Gateway to High-Value Bioplastic Applications. Int. Microbiol. 2013, 16, 1-15. [CrossRef]

67. Liu, Q.; Luo, G.; Zhou, X.R.; Chen, G.-Q. Biosynthesis of Poly(3-Hydroxydecanoate) and 3-Hydroxydodecanoate Dominating Polyhydroxyalkanoates by $\beta$-Oxidation Pathway Inhibited Pseudomonas Putida. Metab. Eng. 2011, 13, 11-17. [CrossRef]

68. Sudesh, K.; Abe, H.; Doi, Y. Synthesis, Structure and Properties of Polyhydroxyalkanoates: Biological Polyesters. Prog. Polym. Sci. 2000, 25, 1503-1555. [CrossRef]

69. Martin, D.P.; Williams, S.F. Medical Applications of Poly-4-Hydroxybutyrate: A Strong Flexible Absorbable Biomaterial. Biochem. Eng. J. 2003, 16, 97-105. [CrossRef]

70. Anjum, A.; Zuber, M.; Zia, K.M.; Noreen, A.; Anjum, M.N.; Tabasum, S. Microbial Production of Polyhydroxyalkanoates (PHAs) and Its Copolymers: A Review of Recent Advancements. Int. J. Biol. Macromol. 2016, 89, 161-174. [CrossRef]

71. Saito, Y.; Doi, Y. Microbial Synthesis and Properties of Poly(3-Hydroxybutyrate-Co-4-Hydroxybutyrate) in Comamonas Acidovorans. Int. J. Biol. Macromol. 1994, 16, 99-104. [CrossRef]

72. Volova, T.G.; Syrvacheva, D.A.; Zhila, N.O.; Sukovatiy, A.G. Synthesis of P(3HB-Co-3HHx) Copolymers Containing High Molar Fraction of 3-Hydroxyhexanoate Monomer by Cupriavidus eutrophus B10646. J. Chem. Technol. Biotechnol. 2016, 91, 416-425. [CrossRef] 
73. Abraham, G.A.; Gallardo, A.; San Roman, J.; Olivera, E.R.; Jodra, R.; García, B.; Miñambres, B.; García, J.L.; Luengo, J.M. Microbial Synthesis of Poly( $\beta$-Hydroxyalkanoates) Bearing Phenyl Groups from Pseudomonas putida: Chemical Structure and Characterization. Biomacromolecules 2001, 2, 562-567. [CrossRef]

74. Mizuno, S.; Katsumata, S.; Hiroe, A.; Tsuge, T. Biosynthesis and Thermal Characterization of Polyhydroxyalkanoates Bearing Phenyl and Phenylalkyl Side Groups. Polym. Degrad. Stab. 2014, 109, 379-384. [CrossRef]

75. Shen, R.; Cai, L.; Meng, D.; Wu, L.; Guo, K.; Dong, G.; Liu, L.; Chen, J.; Wu, Q.; Chen, G. Benzene Containing Polyhydroxyalkanoates Homo- and Copolymers Synthesized by Genome Edited Pseudomonas entomophila. Sci. China Life Sci. 2014, 57, 4-10. [CrossRef]

76. Aróstegui, S.M.; Aponte, M.A.; Díaz, E.; Schröder, E. Bacterial Polyesters Produced by Pseudomonas oleovorans Containing Nitrophenyl Groups. Macromolecules 1999, 32, 2889-2895. [CrossRef]

77. Escapa, I.F.; Morales, V.; Martino, V.P.; Pollet, E.; Avérous, L.; García, J.L.; Prieto, M.A. Disruption of $\beta$-Oxidation Pathway in Pseudomonas putida KT2442 to Produce New Functionalized PHAs with Thioester Groups. Appl. Microbiol. Biotechnol. 2011, 89, 1583-1598. [CrossRef]

78. Arkin, A.H.; Hazer, B. Chemical Modification of Chlorinated Microbial Polyesters. Biomacromolecules 2002, 3, 1327-1335. [CrossRef]

79. Thuronyi, B.W.; Privalsky, T.M.; Chang, M.C.Y. Engineered Fluorine Metabolism and Fluoropolymer Production in Living Cells. Angew. Chem. Int. Ed. 2017, 56, 13637-13640. [CrossRef]

80. Wang, L.-L.; Chen, J.-T.; Wang, L.-F.; Wu, S.; Zhang, G.; Yu, H.-Q.; Ye, X.; Shi, Q.-S. Conformations and Molecular Interactions of Poly- $\gamma$-Glutamic Acid as a Soluble Microbial Product in Aqueous Solutions. Sci. Rep. 2017, 7, 12787. [CrossRef]

81. Matsutani, M.; Ito, K.; Azuma, Y.; Ogino, H.; Shirai, M.; Yakushi, T.; Matsushita, K. Adaptive Mutation Related to Cellulose Producibility in Komagataeibacter medellinensis (Gluconacetobacter xylinus) NBRC 3288. Appl. Microbiol. Biotechnol. 2015, 99, 7229-7240. [CrossRef]

82. Beekmann, U.; Schmölz, L.; Lorkowski, S.; Werz, O.; Thamm, J.; Fischer, D.; Kralisch, D. Process Control and Scale-up of Modified Bacterial Cellulose Production for Tailor-Made Anti-Inflammatory Drug Delivery Systems. Carbohydr. Polym. 2020, $236,116062$. [CrossRef]

83. Campano, C.; Balea, A.; Blanco, A.; Negro, C. Enhancement of the Fermentation Process and Properties of Bacterial Cellulose: A Review. Cellulose 2016, 23, 57-91. [CrossRef]

84. Cakar, F.; Ozer, I.; Aytekin, A.O.; Sahin, F. Improvement Production of Bacterial Cellulose by Semi-Continuous Process in Molasses Medium. Carbohydr. Polym. 2014, 106, 7-13. [CrossRef] [PubMed]

85. Salari, M.; Sowti Khiabani, M.; Rezaei Mokarram, R.; Ghanbarzadeh, B.; Samadi Kafil, H. Preparation and Characterization of Cellulose Nanocrystals from Bacterial Cellulose Produced in Sugar Beet Molasses and Cheese Whey Media. Int. J. Biol. Macromol. 2019, 122, 280-288. [CrossRef] [PubMed]

86. Karmann, S.; Panke, S.; Zinn, M. Fed-Batch Cultivations of Rhodospirillum rubrum Under Multiple Nutrient-Limited Growth Conditions on Syngas as a Novel Option to Produce Poly(3-Hydroxybutyrate) (PHB). Front. Bioeng. Biotechnol. 2019, 7. [CrossRef] [PubMed]

87. Kourmentza, C.; Plácido, J.; Venetsaneas, N.; Burniol-Figols, A.; Varrone, C.; Gavala, H.N.; Reis, M.A.M. Recent Advances and Challenges towards Sustainable Polyhydroxyalkanoate (PHA) Production. Bioengineering 2017, 4, 55. [CrossRef]

88. Koller, M.; Marsalek, L.; de Sousa Dias, M.M.; Braunegg, G. Producing Microbial Polyhydroxyalkanoate (PHA) Biopolyesters in a Sustainable Manner. New Biotechnol. 2017, 37, 24-38. [CrossRef]

89. Davis, R.; Duane, G.; Kenny, S.T.; Cerrone, F.; Guzik, M.W.; Babu, R.P.; Casey, E.; O'Connor, K.E. High Cell Density Cultivation of Pseudomonas putida KT2440 Using Glucose without the Need for Oxygen Enriched Air Supply. Biotechnol. Bioeng. 2015, 112, 725-733. [CrossRef]

90. Richard, A.; Margaritis, A. Rheology, Oxygen Transfer, and Molecular Weight Characteristics of Poly(Glutamic Acid) Fermentation by Bacillus subtilis. Biotechnol. Bioeng. 2003, 82, 299-305. [CrossRef]

91. Fang, J.; Huan, C.; Liu, Y.; Xu, L.; Yan, Z. Bioconversion of Agricultural Waste into Poly-Gamma-Glutamic Acid in Solid-State Bioreactors at Different Scales. Waste Manag. 2020, 102, 939-948. [CrossRef]

92. Tang, B.; Lei, P.; Xu, Z.; Jiang, Y.; Xu, Z.; Liang, J.; Feng, X.; Xu, H. Highly Efficient Rice Straw Utilization for Poly-(GammaGlutamic Acid) Production by Bacillus subtilis NX-2. Bioresour. Technol. 2015, 193, 370-376. [CrossRef]

93. Buescher, J.M.; Margaritis, A. Microbial Biosynthesis of Polyglutamic Acid Biopolymer and Applications in the Biopharmaceutical Biomedical and Food Industries. Crit. Rev. Biotechnol. 2007, 27, 1-19. [CrossRef]

94. Brigham, C. Perspectives for the Biotechnological Production of Biofuels from $\mathrm{CO}_{2}$ and $\mathrm{H}_{2}$ Using Ralstonia eutropha and Other 'Knallgas' Bacteria. Appl. Microbiol. Biotechnol. 2019, 103, 2113-2120. [CrossRef]

95. Papademas, P.; Kotsaki, P. Technological Utilization of Whey towards Sustainable Exploitation. Adv. Dairy Res. 2019, 7, 1-10.

96. Koller, M.; Salerno, A.; Muhr, A.; Reiterer, A.; Chiellini, E.; Sergio, C.; Horvat, P.; Braunegg, G. Whey Lactose as a Raw Material for Microbial Production of Biodegradable Polyesters; TU Graz: Graz, Austria, 2012; pp. 51-92; ISBN 978-953-51-0770-5.

97. Bustamante, D.; Segarra, S.; Tortajada, M.; Ramon, D.; Del Cerro, C.; Auxiliadora Prieto, M.; Iglesias, J.R.; Rojas, A. In Silico Prospection of Microorganisms to Produce Polyhydroxyalkanoate from Whey: Caulobacter segnis DSM 29236 as a Suitable Industrial Strain. Microb. Biotechnol. 2019, 12, 487-501. [CrossRef] 
98. Gustavsson, J.; Cederberg, C.; Sonesson, U.; Otterdijk, R.; McYbeck, A. Global Food Losses and Food Waste: Extent, Causes and Prevention; Food and Agriculture Organization of the United Nations: Rome, Italy, 2011.

99. Heng, K.-S.; Hatti-Kaul, R.; Adam, F.; Fukui, T.; Sudesh, K. Conversion of Rice Husks to Polyhydroxyalkanoates (PHA) via a Three-Step Process: Optimized Alkaline Pretreatment, Enzymatic Hydrolysis, and Biosynthesis by Burkholderia Cepacia USM (JCM 15050). J. Chem. Technol. Biotechnol. 2017, 92, 100-108. [CrossRef]

100. Abdelraof, M.; Hasanin, M.S.; El-Saied, H. Ecofriendly Green Conversion of Potato Peel Wastes to High Productivity Bacterial Cellulose. Carbohydr. Polym. 2019, 211, 75-83. [CrossRef]

101. Skiba, E.A.; Budaeva, V.V.; Ovchinnikova, E.V.; Gladysheva, E.K.; Kashcheyeva, E.I.; Pavlov, I.N.; Sakovich, G. V A Technology for Pilot Production of Bacterial Cellulose from Oat Hulls. Chem. Eng. J. 2020, 383, 123128. [CrossRef]

102. Kulpreecha, S.; Boonruangthavorn, A.; Meksiriporn, B.; Thongchul, N. Inexpensive Fed-Batch Cultivation for High Poly(3Hydroxybutyrate) Production by a New Isolate of Bacillus megaterium. J. Biosci. Bioeng. 2009, 107, 240-245. [CrossRef]

103. Bae, S.O.; Shoda, M. Production of Bacterial Cellulose by Acetobacter xylinum BPR2001 Using Molasses Medium in a Jar Fermentor. Appl. Microbiol. Biotechnol. 2005, 67, 45-51. [CrossRef]

104. Zhang, D.; Feng, X.; Zhou, Z.; Zhang, Y.; Xu, H. Economical Production of Poly( $\gamma$-Glutamic Acid) Using Untreated Cane Molasses and Monosodium Glutamate Waste Liquor by Bacillus subtilis NX-2. Bioresour. Technol. 2012, 114, 583-588. [CrossRef]

105. Feng, X.; Tang, B.; Jiang, Y.; Xu, Z.; Lei, P.; Liang, J.; Xu, H. Efficient Production of Poly- $\gamma$-Glutamic Acid from Cane Molasses by Bacillus subtilis NX-2 Immobilized on Chemically Modified Sugarcane Bagasse. J. Chem. Technol. Biotechnol. 2016, 91, 2085-2093. [CrossRef]

106. Nielsen, C.; Rahman, A.; Rehman, A.U.; Walsh, M.K.; Miller, C.D. Food Waste Conversion to Microbial Polyhydroxyalkanoates. Microb. Biotechnol. 2017, 10, 1338-1352. [CrossRef] [PubMed]

107. Obruca, S.; Petrik, S.; Benesova, P.; Svoboda, Z.; Eremka, L.; Marova, I. Utilization of Oil Extracted from Spent Coffee Grounds for Sustainable Production of Polyhydroxyalkanoates. Appl. Microbiol. Biotechnol. 2014, 98, 5883-5890. [CrossRef] [PubMed]

108. Kamilah, H.; Al-Gheethi, A.; Yang, T.; Sudesh, K. Correction to: The Use of Palm Oil-Based Waste Cooking Oil to Enhance the Production of Polyhydroxybutyrate $[\mathrm{P}(3 \mathrm{HB})]$ by Cupriavidus necator H16 Strain. Arab. J. Sci. Eng. 2018, 44. [CrossRef]

109. Taniguchi, I.; Kagotani, K.; Kimura, Y. Microbial Production of Poly(Hydroxyalkanoate)s from Waste Edible Oils. Green Chem. 2003, 5, 545-548. [CrossRef]

110. Fernández, D.; Rodríguez, E.; Bassas, M.; Viñas, M.; Solanas, A.M.; Llorens, J.; Marqués, A.M.; Manresa, A. Agro-Industrial Oily Wastes as Substrates for PHA Production by the New Strain Pseudomonas aeruginosa NCIB 40045: Effect of Culture Conditions. Biochem. Eng. J. 2005, 26, 159-167. [CrossRef]

111. Żywicka, A.; Junka, A.; Szymczyk, P.; Chodaczek, G.; Grzesiak, J.; Sedghizadeh, P.; Fijałkowski, K. Bacterial Cellulose Yield Increased over 500\% by Supplementation of Medium with Vegetable Oil. Carbohydr. Polym. 2018, 199. [CrossRef]

112. Berwig, K.H.; Baldasso, C.; Dettmer, A. Production and Characterization of Poly(3-Hydroxybutyrate) Generated by Alcaligenes Latus Using Lactose and Whey after Acid Protein Precipitation Process. Bioresour. Technol. 2016, 218, 31-37. [CrossRef]

113. Pais, J.; Serafim, L.S.; Freitas, F.; Reis, M.A.M. Conversion of Cheese Whey into Poly(3-Hydroxybutyrate-Co-3-Hydroxyvalerate) by Haloferax mediterranei. New Biotechnol. 2016, 33, 224-230. [CrossRef]

114. Povolo, S.; Toffano, P.; Basaglia, M.; Casella, S. Polyhydroxyalkanoates Production by Engineered Cupriavidus necator from Waste Material Containing Lactose. Bioresour. Technol. 2010, 101, 7902-7907. [CrossRef]

115. Bekatorou, A.; Plioni, I.; Sparou, K.; Maroutsiou, R.; Tsafrakidou, P.; Petsi, T.; Kordouli, E. Bacterial Cellulose Production Using the Corinthian Currant Finishing Side-Stream and Cheese Whey: Process Optimization and Textural Characterization. Foods 2019, 8. [CrossRef]

116. Battad-Bernardo, E.; McCrindle, S.L.; Couperwhite, I.; Neilan, B.A. Insertion of an E. Coli LacZ Gene in Acetobacter xylinus for the Production of Cellulose in Whey. FEMS Microbiol. Lett. 2004, 231, 253-260. [CrossRef]

117. Chaudhry, W.N.; Jamil, N.; Ali, I.; Ayaz, M.H.; Hasnain, S. Screening for Polyhydroxyalkanoate (PHA)-Producing Bacterial Strains and Comparison of PHA Production from Various Inexpensive Carbon Sources. Ann. Microbiol. 2011, 61, 623-629. [CrossRef]

118. Albuquerque, M.; Torres, C.A.V.; Reis, M. Polyhydroxyalkanoate (PHA) Production by a Mixed Microbial Culture Using Sugar Molasses: Effect of the Influent Substrate Concentration on Culture Selection. Water Res. 2010, 44, 3419-3433. [CrossRef]

119. Kumar, V.; Sharma, D.K.; Bansal, V.; Mehta, D.; Sangwan, R.S.; Yadav, S.K. Efficient and Economic Process for the Production of Bacterial Cellulose from Isolated Strain of Acetobacter pasteurianus of RSV-4 Bacterium. Bioresour. Technol. 2019, $275,430-433$. [CrossRef]

120. Pramanik, A.; Mitra, A.; Arumugam, M.; Bhattacharyya, A.; Sadhukhan, S.; Ray, A.; Haldar, S.; Mukhopadhyay, U.K.; Mukherjee, J. Utilization of Vinasse for the Production of Polyhydroxybutyrate by Haloarcula marismortui. Folia Microbiol. Praha 2012, 57, 71-79. [CrossRef]

121. Yu, J.; Stahl, H. Microbial Utilization and Biopolyester Synthesis of Bagasse Hydrolysates. Bioresour. Technol. 2008, 99, 8042-8048. [CrossRef]

122. Silva, L.F.; Taciro, M.K.; Michelin Ramos, M.E.; Carter, J.M.; Pradella, J.G.C.; Gomez, J.G.C. Poly-3-Hydroxybutyrate (P3HB) Production by Bacteria from Xylose, Glucose and Sugarcane Bagasse Hydrolysate. J. Ind. Microbiol. Biotechnol. 2004, 31, 245-254. [CrossRef]

123. Follonier, S.; Riesen, R.; Zinn, M. Pilot-Scale Production of Functionalized Mcl-PHA from Grape Pomace Supplemented with Fatty Acids. Chem. Biochem. Eng. Q. 2015, 29, 113-121. [CrossRef] 
124. Lin, D.; Lopez-Sanchez, P.; Li, R.; Li, Z. Production of Bacterial Cellulose by Gluconacetobacter hansenii CGMCC 3917 Using Only Waste Beer Yeast as Nutrient Source. Bioresour. Technol. 2014, 151, 113-119. [CrossRef]

125. Fan, X.; Gao, Y.; He, W.; Hu, H.; Tian, M.; Wang, K.; Pan, S. Production of Nano Bacterial Cellulose from Beverage Industrial Waste of Citrus Peel and Pomace Using Komagataeibacter xylinus. Carbohydr. Polym. 2016, 151, 1068-1072. [CrossRef] [PubMed]

126. Kurosumi, A.; Sasaki, C.; Yamashita, Y.; Nakamura, Y. Utilization of Various Fruit Juices as Carbon Source for Production of Bacterial Cellulose by Acetobacter xylinum NBRC 13693. Carbohydr. Polym. 2009, 76, 333-335. [CrossRef]

127. Yang, X.Y.; Huang, C.; Guo, H.J.; Xiong, L.; Luo, J.; Wang, B.; Lin, X.Q.; Chen, X.F.; Chen, X.D. Bacterial Cellulose Production from the Litchi Extract by Gluconacetobacter xylinus. Prep. Biochem. Biotechnol. 2016, 46, 39-43. [CrossRef]

128. Jozala, A.F.; Pertile, R.A.; dos Santos, C.A.; de Carvalho Santos-Ebinuma, V.; Seckler, M.M.; Gama, F.M.; Pessoa Jr., A. Bacterial Cellulose Production by Gluconacetobacter xylinus by Employing Alternative Culture Media. Appl. Microbiol. Biotechnol. 2015, 99, 1181-1190. [CrossRef]

129. Rani, M.U.; Appaiah, K.A. Production of Bacterial Cellulose by Gluconacetobacter hansenii UAC09 Using Coffee Cherry Husk. J. Food Sci. Technol. 2013, 50, 755-762. [CrossRef] [PubMed]

130. Gomes, F.P.; Silva, N.H.C.S.; Trovatti, E.; Serafim, L.S.; Duarte, M.F.; Silvestre, A.J.D.; Neto, C.P.; Freire, C.S.R. Production of Bacterial Cellulose by Gluconacetobacter sacchari Using Dry Olive Mill Residue. Biomass Bioenergy 2013, 55, 205-211. [CrossRef]

131. Jiang, K.; Tang, B.; Wang, Q.; Xu, Z.; Sun, L.; Ma, J.; Li, S.; Xu, H.; Lei, P. The Bio-Processing of Soybean Dregs by Solid State Fermentation Using a Poly Gamma-Glutamic Acid Producing Strain and Its Effect as Feed Additive. Bioresour Technol 2019, 291, 121841. [CrossRef]

132. López-Cuellar, M.R.; Alba-Flores, J.; Rodríguez, J.N.G.; Pérez-Guevara, F. Production of Polyhydroxyalkanoates (PHAs) with Canola Oil as Carbon Source. Int. J. Biol. Macromol. 2011, 48, 74-80. [CrossRef]

133. Anne, E.; Le Grand, A.; Yves-Marie, C.; le fellic, M.; Hachet, N.; Le Tilly, V.; Loulergue, P.; Audic, J.-L.; Bruzaud, S. Valorisation of Local Agro-Industrial Processing Waters as Growth Media for Polyhydroxyalkanoates (PHA) Production. Ind. Crop. Prod. 2016, 80, 1-5. [CrossRef]

134. Gayathri, G.; Srinikethan, G. Bacterial Cellulose Production by K. saccharivorans BC1 Strain Using Crude Distillery Effluent as Cheap and Cost Effective Nutrient Medium. Int. J. Biol. Macromol. 2019, 138, 950-957. [CrossRef]

135. Wu, J.M.; Liu, R.H. Thin Stillage Supplementation Greatly Enhances Bacterial Cellulose Production by Gluconacetobacter Xylinus. Carbohydr. Polym. 2012, 90, 116-121. [CrossRef]

136. Huang, C.; Guo, H.J.; Xiong, L.; Wang, B.; Shi, S.L.; Chen, X.F.; Lin, X.Q.; Wang, C.; Luo, J.; Chen, X.D. Using Wastewater after Lipid Fermentation as Substrate for Bacterial Cellulose Production by Gluconacetobacter xylinus. Carbohydr. Polym. 2016, 136, 198-202. [CrossRef]

137. Erbas Kiziltas, E.; Kiziltas, A.; Gardner, D.J. Synthesis of Bacterial Cellulose Using Hot Water Extracted Wood Sugars. Carbohydr. Polym. 2015, 124, 131-138. [CrossRef]

138. Huang, C.; Yang, X.Y.; Xiong, L.; Guo, H.J.; Luo, J.; Wang, B.; Zhang, H.R.; Lin, X.Q.; Chen, X.D. Evaluating the Possibility of Using Acetone-Butanol-Ethanol (ABE) Fermentation Wastewater for Bacterial Cellulose Production by Gluconacetobacter xylinus. Lett. Appl. Microbiol. 2015, 60, 491-496. [CrossRef]

139. Li, Z.; Wang, L.; Hua, J.; Jia, S.; Zhang, J.; Liu, H. Production of Nano Bacterial Cellulose from Waste Water of Candied Jujube-Processing Industry Using Acetobacter xylinum. Carbohydr. Polym. 2015, 120, 115-119. [CrossRef]

140. Campanari, S.; e Silva, F.A.; Bertin, L.; Villano, M.; Majone, M. Effect of the Organic Loading Rate on the Production of Polyhydroxyalkanoates in a Multi-Stage Process Aimed at the Valorization of Olive Oil Mill Wastewater. Int. J. Biol. Macromol. 2014, 71, 34-41. [CrossRef]

141. Farghaly, A.; Enitan, A.M.; Kumari, S.; Bux, F.; Tawfik, A. Polyhydroxyalkanoates Production from Fermented Paperboard Mill Wastewater Using Acetate-Enriched Bacteria. Clean Technol. Environ. Policy 2017, 19, 935-947. [CrossRef]

142. Tamisa, J.; Luzkov, K.; Jiang, Y.; van Loosdrecht, M.C.; Kleerebezem, R. Enrichment of Plasticicumulans acidivorans at Pilot-Scale for PHA Production on Industrial Wastewater. J. Biotechnol. 2014, 192 Pt A, 161-169. [CrossRef]

143. Moretto, G.; Russo, I.; Bolzonella, D.; Pavan, P.; Majone, M.; Valentino, F. An Urban Biorefinery for Food Waste and Biological Sludge Conversion into Polyhydroxyalkanoates and Biogas. Water Res. 2020, 170, 115371. [CrossRef]

144. Valentino, F.; Moretto, G.; Lorini, L.; Bolzonella, D.; Pavan, P.; Majone, M. Pilot-Scale Polyhydroxyalkanoate Production from Combined Treatment of Organic Fraction of Municipal Solid Waste and Sewage Sludge. Ind. Eng. Chem. Res. 2019, 58, 12149-12158. [CrossRef]

145. Elmowafy, E.; Abdal-Hay, A.; Skouras, A.; Tiboni, M.; Casettari, L.; Guarino, V. Polyhydroxyalkanoate (PHA): Applications in Drug Delivery and Tissue Engineering. Expert Rev. Med. Devices 2019, 16, 467-482. [CrossRef]

146. Salmaso, S.; Caliceti, P. Stealth Properties to Improve Therapeutic Efficacy of Drug Nanocarriers. J. Drug Deliv. 2013, $2013,374252$. [CrossRef]

147. Amoozgar, Z.; Yeo, Y. Recent Advances in Stealth Coating of Nanoparticle Drug Delivery Systems. WIREs Nanomed. Nanobiotechnology 2012, 4, 219-233. [CrossRef]

148. Hu, J.; Wang, M.; Xiao, X.; Zhang, B.; Xie, Q.; Xu, X.; Li, S.; Zheng, Z.; Wei, D.; Zhang, X. A Novel Long-Acting Azathioprine Polyhydroxyalkanoate Nanoparticle Enhances Treatment Efficacy for Systemic Lupus Erythematosus with Reduced Side Effects. Nanoscale 2020, 12, 10799-10808. [CrossRef] 
149. Urimi, D.; Agrawal, A.K.; Kushwah, V.; Jain, S. Polyglutamic Acid Functionalization of Chitosan Nanoparticles Enhances the Therapeutic Efficacy of Insulin Following Oral Administration. AAPS PharmSciTech 2019, 20, 131. [CrossRef]

150. Shao, W.; Liu, H.; Wang, S.; Wu, J.; Huang, M.; Min, H.; Liu, X. Controlled Release and Antibacterial Activity of Tetracycline Hydrochloride-Loaded Bacterial Cellulose Composite Membranes. Carbohydr. Polym. 2016, 145, 114-120. [CrossRef]

151. Silva, N.H.C.S.; Rodrigues, A.F.; Almeida, I.F.; Costa, P.C.; Rosado, C.; Neto, C.P.; Silvestre, A.J.D.; Freire, C.S.R. Bacterial Cellulose Membranes as Transdermal Delivery Systems for Diclofenac: In Vitro Dissolution and Permeation Studies. Carbohydr. Polym. 2014, 106, 264-269. [CrossRef]

152. Dutta, S.D.; Patel, D.K.; Lim, K.T. Functional Cellulose-Based Hydrogels as Extracellular Matrices for Tissue Engineering. J. Biol Eng. 2019, 13, 55. [CrossRef]

153. Lim, J.; You, M.; Li, J.; Li, Z. Emerging Bone Tissue Engineering via Polyhydroxyalkanoate (PHA)-Based Scaffolds. Mater. Sci Eng. C Mater. Biol. Appl. 2017, 79, 917-929. [CrossRef]

154. Codreanu, A.; Balta, C.; Herman, H.; Cotoraci, C.; Mihali, C.V.; Zurbau, N.; Zaharia, C.; Rapa, M.; Stanescu, P.; Radu, I.C.; et al. Bacterial Cellulose-Modified Polyhydroxyalkanoates Scaffolds Promotes Bone Formation in Critical Size Calvarial Defects in Mice. Mater. Basel 2020, 13. [CrossRef]

155. Nemati Hayati, A.; Hosseinalipour, S.M.; Rezaie, H.R.; Shokrgozar, M.A. Characterization of Poly(3-Hydroxybutyrate)/NanoHydroxyapatite Composite Scaffolds Fabricated without the Use of Organic Solvents for Bone Tissue Engineering Applications. Mater. Sci. Eng. C 2012, 32, 416-422. [CrossRef]

156. Khan, S.; Ul-Islam, M.; Ikram, M.; Islam, S.U.; Ullah, M.W.; Israr, M.; Jang, J.H.; Yoon, S.; Park, J.K. Preparation and Structural Characterization of Surface Modified Microporous Bacterial Cellulose Scaffolds: A Potential Material for Skin Regeneration Applications in Vitro and in Vivo. Int. J. Biol. Macromol. 2018, 117, 1200-1210. [CrossRef] [PubMed]

157. Yang, R.; Wang, X.; Liu, S.; Zhang, W.; Wang, P.; Liu, X.; Ren, Y.; Tan, X.; Chi, B. Bioinspired Poly (Gamma-Glutamic Acid) Hydrogels for Enhanced Chondrogenesis of Bone Marrow-Derived Mesenchymal Stem Cells. Int J. Biol Macromol 2020, 142, 332-344. [CrossRef] [PubMed]

158. Constantinides, C.; Basnett, P.; Lukasiewicz, B.; Carnicer, R.; Swider, E.; Majid, Q.A.; Srinivas, M.; Carr, C.A.; Roy, I. In Vivo Tracking and 1H/19F Magnetic Resonance Imaging of Biodegradable Polyhydroxyalkanoate/Polycaprolactone Blend Scaffolds Seeded with Labeled Cardiac Stem Cells. ACS Appl. Mater. Interfaces 2018, 10, 25056-25068. [CrossRef]

159. Milleret, V.; Hefti, T.; Hall, H.; Vogel, V.; Eberli, D. Influence of the Fiber Diameter and Surface Roughness of Electrospun Vascular Grafts on Blood Activation. Acta Biomater. 2012, 8, 4349-4356. [CrossRef] [PubMed]

160. Wan, Y.; Yang, S.; Peng, M.; Gama, M.; Yang, Z.; Deng, X.; Zhou, J.; Ouyang, C.; Luo, H. Controllable Synthesis of Biomimetic Nano/Submicro-Fibrous Tubes for Potential Small-Diameter Vascular Grafts. J. Mater. Chem. B 2020, 8, 5694-5706. [CrossRef]

161. Sodian, R.; Sperling, J.S.; Martin, D.P.; Egozy, A.; Stock, U.; Mayer, J.E.; Vacanti, J.P. Technical Report: Fabrication of a Trileaflet Heart Valve Scaffold from a Polyhydroxyalkanoate Biopolyester for Use in Tissue Engineering. Tissue Eng. 2000, 6, 183-188. [CrossRef]

162. Wu, S.; Liu, Y.-L.; Cui, B.; Qu, X.-H.; Chen, G.-Q. Study on Decellularized Porcine Aortic Valve/Poly (3-Hydroxybutyrate-Co-3Hydroxyhexanoate) Hybrid Heart Valve in Sheep Model. Artif. Organs 2007, 31, 689-697. [CrossRef]

163. Protopopov, A.V.; Kochkina, T.A.; Konstantinov, E.P.; Shishatskaya, E.I.; Efremov, S.N.; Volova, T.G.; Gitelson, I.I. Investigation of Application of PHA Coating to Enhance Biocompatibility of Vascular Stents. Dokl. Biol. Sci. 2005, 401, 85-87. [CrossRef]

164. Aboelnaga, A.; Elmasry, M.; Adly, O.A.; Elbadawy, M.A.; Abbas, A.H.; Abdelrahman, I.; Salah, O.; Steinvall, I. Microbial Cellulose Dressing Compared with Silver Sulphadiazine for the Treatment of Partial Thickness Burns: A Prospective, Randomised, Clinical Trial. Burns 2018, 44, 1982-1988. [CrossRef]

165. Portela, R.; Leal, C.R.; Almeida, P.L.; Sobral, R.G. Bacterial Cellulose: A Versatile Biopolymer for Wound Dressing Applications. Microb. Biotechnol. 2019, 12, 586-610. [CrossRef]

166. Shishatskaya, E.I.; Nikolaeva, E.D.; Vinogradova, O.N.; Volova, T.G. Experimental Wound Dressings of Degradable PHA for Skin Defect Repair. J. Mater. Sci. Mater. Med. 2016, 27, 165. [CrossRef]

167. Liu, W.-C.; Wang, H.-Y.; Lee, T.-H.; Chung, R.-J. Gamma-Poly Glutamate/Gelatin Composite Hydrogels Crosslinked by Proanthocyanidins for Wound Healing. Mater. Sci. Eng. C 2019, 101, 630-639. [CrossRef]

168. Dennis, C.; Sethu, S.; Nayak, S.; Mohan, L.; Morsi, Y.Y.; Manivasagam, G. Suture Materials—Current and Emerging Trends. J. Biomed. Mater. Res. A 2016, 104, 1544-1559. [CrossRef]

169. Matz, D.; Teuteberg, S.; Wiencierz, A.; Soysal, S.D.; Heizmann, O. Do Antibacterial Skin Sutures Reduce Surgical Site Infections after Elective Open Abdominal Surgery?-Study Protocol of a Prospective, Randomized Controlled Single Center Trial. Trials 2019, 20, 390. [CrossRef]

170. Hsu, S.H.; Lin, C.H. The Properties of Gelatin-Poly (Gamma-Glutamic Acid) Hydrogels as Biological Glues. Biorheology 2007, 44, 17-28.

171. Chen, G.-Q.; Jiang, X.-R.; Guo, Y. Synthetic Biology of Microbes Synthesizing Polyhydroxyalkanoates (PHA). Synth. Syst. Biotechnol. 2016, 1, 236-242. [CrossRef]

172. Chen, G.-Q.; Hajnal, I. The 'PHAome'. Trends Biotechnol. 2015, 33, 559-564. [CrossRef]

173. Ouyang, S.-P.; Luo, R.C.; Chen, S.-S.; Liu, Q.; Chung, A.; Wu, Q.; Chen, G.-Q. Production of Polyhydroxyalkanoates with High 3Hydroxydodecanoate Monomer Content by FadB and FadA Knockout Mutant of Pseudomonas Putida KT2442. Biomacromolecules 2007, 8, 2504-2511. [CrossRef] 
174. Tripathi, L.; Wu, L.-P.; Dechuan, M.; Chen, J.; Wu, Q.; Chen, G.-Q. Pseudomonas Putida KT2442 as a Platform for the Biosynthesis of Polyhydroxyalkanoates with Adjustable Monomer Contents and Compositions. Bioresour. Technol. 2013, 142, $225-231$. [CrossRef]

175. Vigneswari, S.; Vijaya, S.; Majid, M.I.A.; Sudesh, K.; Sipaut, C.S.; Azizan, M.N.M.; Amirul, A.A. Enhanced Production of Poly(3-Hydroxybutyrate-Co-4-Hydroxybutyrate) Copolymer with Manipulated Variables and Its Properties. J. Ind. Microbiol. Biotechnol. 2009, 36, 547-556. [CrossRef] [PubMed]

176. Ballistreri, A.; Giuffrida, M.; Guglielmino, S.P.P.; Carnazza, S.; Ferreri, A.; Impallomeni, G. Biosynthesis and Structural Characterization of Medium-Chain-Length Poly(3-Hydroxyalkanoates) Produced by Pseudomonas aeruginosa from Fatty Acids. Int. J. Biol. Macromol. 2001, 29, 107-114. [CrossRef]

177. Ewering, C.; Lütke-Eversloh, T.; Luftmann, H.; Steinbüchel, A. Identification of Novel Sulfur-Containing Bacterial Polyesters: Biosynthesis of Poly(3-Hydroxy-S-Propyl- $\omega$-Thioalkanoates) Containing Thioether Linkages in the Side Chains. Microbiology 2002, 148, 1397-1406. [CrossRef]

178. Dinjaski, N.; Fernández-Gutiérrez, M.; Selvam, S.; Parra-Ruiz, F.J.; Lehman, S.M.; San Román, J.; García, E.; García, J.L.; García, A.J.; Prieto, M.A. PHACOS, a Functionalized Bacterial Polyester with Bactericidal Activity against Methicillin-Resistant Staphylococcus aureus. Biomaterials 2014, 35, 14-24. [CrossRef] [PubMed]

179. Florea, M.; Hagemann, H.; Santosa, G.; Abbott, J.; Micklem, C.N.; Spencer-Milnes, X.; de Arroyo Garcia, L.; Paschou, D.; Lazenbatt, C.; Kong, D.; et al. Engineering Control of Bacterial Cellulose Production Using a Genetic Toolkit and a New Cellulose-Producing Strain. Proc. Natl. Acad. Sci. USA 2016, 113, E3431-E3440. [CrossRef] [PubMed]

180. Teh, M.Y.; Ooi, K.H.; Danny Teo, S.X.; Bin Mansoor, M.E.; Shaun Lim, W.Z.; Tan, M.H. An Expanded Synthetic Biology Toolkit for Gene Expression Control in Acetobacteraceae. ACS Synth. Biol. 2019, 8, 708-723. [CrossRef] [PubMed]

181. Fang, J.; Kawano, S.; Tajima, K.; Kondo, T. In Vivo Curdlan/Cellulose Bionanocomposite Synthesis by Genetically Modified Gluconacetobacter Xylinus. Biomacromolecules 2015, 16, 3154-3160. [CrossRef]

182. Gao, M.; Li, J.; Bao, Z.; Hu, M.; Nian, R.; Feng, D.; An, D.; Li, X.; Xian, M.; Zhang, H. A Natural in Situ Fabrication Method of Functional Bacterial Cellulose Using a Microorganism. Nat. Commun. 2019, 10, 437. [CrossRef]

183. Yadav, V.; Sun, L.; Panilaitis, B.; Kaplan, D.L. In Vitro Chondrogenesis with Lysozyme Susceptible Bacterial Cellulose as a Scaffold. J. Tissue Eng. Regen. Med. 2015, 9, E276-E288. [CrossRef]

184. Halmschlag, B.; Steurer, X.; Putri, S.P.; Fukusaki, E.; Blank, L.M. Tailor-Made Poly- $\gamma$-Glutamic Acid Production. Metab. Eng. 2019, 55, 239-248. [CrossRef]

185. Poo, H.; Park, C.; Kwak, M.-S.; Choi, D.-Y.; Hong, S.-P.; Lee, I.-H.; Lim, Y.T.; Choi, Y.K.; Bae, S.-R.; Uyama, H.; et al. New Biological Functions and Applications of High-Molecular-Mass Poly- $\gamma$-Glutamic Acid. Chem. Biodivers. 2010, 7, 1555-1562. [CrossRef]

186. Khalil, I.R.; Burns, A.T.; Radecka, I.; Kowalczuk, M.; Khalaf, T.; Adamus, G.; Johnston, B.; Khechara, M.P. Bacterial-Derived Polymer Poly-y-Glutamic Acid (y-PGA)-Based Micro/Nanoparticles as a Delivery System for Antimicrobials and Other Biomedical Applications. Int. J. Mol. Sci. 2017, 18. [CrossRef]

187. Stumpf, T.R.; Yang, X.; Zhang, J.; Cao, X. In Situ and Ex Situ Modifications of Bacterial Cellulose for Applications in Tissue Engineering. Mater. Sci. Eng. C 2018, 82, 372-383. [CrossRef]

188. Butchosa, N.; Brown, C.; Larsson, P.T.; Berglund, L.A.; Bulone, V.; Zhou, Q. Nanocomposites of Bacterial Cellulose Nanofibers and Chitin Nanocrystals: Fabrication, Characterization and Bactericidal Activity. Green Chem. 2013, 15, 3404-3413. [CrossRef]

189. Zhang, P.; Chen, L.; Zhang, Q.; Hong, F.F. Using In Situ Dynamic Cultures to Rapidly Biofabricate Fabric-Reinforced Composites of Chitosan/Bacterial Nanocellulose for Antibacterial Wound Dressings. Front. Microbiol. 2016, 7, 260. [CrossRef]

190. Abdelraof, M.; Hasanin, M.S.; Farag, M.M.; Ahmed, H.Y. Green Synthesis of Bacterial Cellulose/Bioactive Glass Nanocomposites: Effect of Glass Nanoparticles on Cellulose Yield, Biocompatibility and Antimicrobial Activity. Int. J. Biol. Macromol. 2019, 138, 975-985. [CrossRef]

191. Chen, J.; Chen, C.; Liang, G.; Xu, X.; Hao, Q.; Sun, D. In Situ Preparation of Bacterial Cellulose with Antimicrobial Properties from Bioconversion of Mulberry Leaves. Carbohydr. Polym. 2019, 220, 170-175. [CrossRef]

192. Castro-Mayorga, J.L.; Freitas, F.; Reis, M.A.M.; Prieto, M.A.; Lagaron, J.M. Biosynthesis of Silver Nanoparticles and Polyhydroxybutyrate Nanocomposites of Interest in Antimicrobial Applications. Int. J. Biol. Macromol. 2018, 108, 426-435. [CrossRef]

193. Geng, Y.; Wang, S.; Qi, Q. Expression of Active Recombinant Human Tissue-Type Plasminogen Activator by Using in Vivo Polyhydroxybutyrate Granule Display. Appl. Environ. Microbiol. 2010, 76, 7226-7230. [CrossRef]

194. Yao, Y.C.; Zhan, X.Y.; Zhang, J.; Zou, X.H.; Wang, Z.H.; Xiong, Y.C.; Chen, J.; Chen, G.Q. A Specific Drug Targeting System Based on Polyhydroxyalkanoate Granule Binding Protein PhaP Fused with Targeted Cell Ligands. Biomaterials 2008, 29, $4823-4830$. [CrossRef]

195. Fan, F.; Wang, L.; Ouyang, Z.; Wen, Y.; Lu, X. Development and Optimization of a Tumor Targeting System Based on Microbial Synthesized PHA Biopolymers and PhaP Mediated Functional Modification. Appl. Microbiol. Biotechnol. 2018, 102, 3229-3241. [CrossRef] [PubMed]

196. Lee, J.; Jung, S.-G.; Park, C.-S.; Kim, H.-Y.; Batt, C.; Kim, Y.-R. Tumor-Specific Hybrid Polyhydroxybutyrate Nanoparticle: Surface Modification of Nanoparticle by Enzymatically Synthesized Functional Block Copolymer. Bioorg. Med. Chem. Lett. 2011, 21, 2941-2944. [CrossRef] [PubMed]

197. Lee, S.J.; Park, J.P.; Park, T.J.; Lee, S.Y.; Lee, S.; Park, J.K. Selective Immobilization of Fusion Proteins on Poly(Hydroxyalkanoate) Microbeads. Anal. Chem. 2005, 77, 5755-5759. [CrossRef] [PubMed] 
198. Park, T.J.; Yoo, S.; Keum, K.; Lee, S.Y. Microarray of DNA-Protein Complexes on Poly-3-Hydroxybutyrate Surface for Pathogen Detection. Anal. Bioanal. Chem. 2009, 393, 1639-1647. [CrossRef] [PubMed]

199. Backstrom, B.T.; Brockelbank, J.A.; Rehm, B.H. Recombinant Escherichia coli Produces Tailor-Made Biopolyester Granules for Applications in Fluorescence Activated Cell Sorting: Functional Display of the Mouse Interleukin-2 and Myelin Oligodendrocyte Glycoprotein. BMC Biotechnol. 2007, 7, 3. [CrossRef] [PubMed]

200. Parlane, N.A.; Chen, S.; Jones, G.J.; Vordermeier, H.M.; Wedlock, D.N.; Rehm, B.H.A.; Buddle, B.M. Display of Antigens on Polyester Inclusions Lowers the Antigen Concentration Required for a Bovine Tuberculosis Skin Test. Clin. Vaccine Immunol. 2016, 23, 19-26. [CrossRef]

201. Dong, Y.; Li, P.; Chen, C.B.; Wang, Z.H.; Ma, P.; Chen, G.Q. The Improvement of Fibroblast Growth on Hydrophobic Biopolyesters by Coating with Polyhydroxyalkanoate Granule Binding Protein PhaP Fused with Cell Adhesion Motif RGD. Biomaterials 2010, 31, 8921-8930. [CrossRef]

202. You, M.; Peng, G.; Li, J.; Ma, P.; Wang, Z.; Shu, W.; Peng, S.; Chen, G.Q. Chondrogenic Differentiation of Human Bone Marrow Mesenchymal Stem Cells on Polyhydroxyalkanoate (PHA) Scaffolds Coated with PHA Granule Binding Protein PhaP Fused with RGD Peptide. Biomaterials 2011, 32, 2305-2313. [CrossRef]

203. Xie, H.; Li, J.; Li, L.; Dong, Y.; Chen, G.Q.; Chen, K.C. Enhanced Proliferation and Differentiation of Neural Stem Cells Grown on PHA Films Coated with Recombinant Fusion Proteins. Acta Biomater. 2013, 9, 7845-7854. [CrossRef]

204. Ke, Y.; Liu, C.; Zhang, X.; Xiao, M.; Wu, G. Surface Modification of Polyhydroxyalkanoates toward Enhancing Cell Compatibility and Antibacterial Activity. Macromol. Mater. Eng. 2017, 302, 1700258. [CrossRef]

205. Parlane, N.A.; Grage, K.; Lee, J.W.; Buddle, B.M.; Denis, M.; Rehm, B.H.A. Production of a Particulate Hepatitis C Vaccine Candidate by an Engineered Lactococcus Lactis Strain. Appl. Environ. Microbiol. 2011, 77, 8516-8522. [CrossRef] [PubMed]

206. Martínez-Donato, G.; Piniella, B.; Aguilar, D.; Olivera, S.; Pérez, A.; Castañedo, Y.; Alvarez-Lajonchere, L.; Dueñas-Carrera, S.; Lee, J.W.; Burr, N.; et al. Protective T Cell and Antibody Immune Responses against Hepatitis C Virus Achieved Using a Biopolyester-Bead-Based Vaccine Delivery System. Clin. Vaccine Immunol. CVI 2016, 23, 370-378. [CrossRef] [PubMed]

207. Xue, Q.; Liu, X.B.; Lao, Y.H.; Wu, L.P.; Wang, D.; Zuo, Z.Q.; Chen, J.Y.; Hou, J.; Bei, Y.Y.; Wu, X.F.; et al. Anti-Infective Biomaterials with Surface-Decorated Tachyplesin I. Biomaterials 2018, 178, 351-362. [CrossRef] [PubMed]

208. Levy, I.; Shoseyov, O. Cellulose-Binding Domains: Biotechnological Applications. Biotechnol. Adv. 2002, 20, 191-213. [CrossRef]

209. Sugimoto, N.; Igarashi, K.; Samejima, M. Cellulose Affinity Purification of Fusion Proteins Tagged with Fungal Family 1 Cellulose-Binding Domain. Protein Expr. Purif. 2012, 82, 290-296. [CrossRef]

210. Kumar, A.; Zhang, S.; Wu, G.; Wu, C.C.; Chen, J.; Baskaran, R.; Liu, Z. Cellulose Binding Domain Assisted Immobilization of Lipase (GSlip-CBD) onto Cellulosic Nanogel: Characterization and Application in Organic Medium. Colloids Surf. B Biointerfaces 2015, 136, 1042-1050. [CrossRef]

211. Xiao, Z.; Gao, P.; Qu, Y.; Wang, T. Cellulose-Binding Domain of Endoglucanase III from Trichoderma Reesei Disrupting the Structure of Cellulose. Biotechnol. Lett. 2001, 23, 711-715. [CrossRef]

212. Andrade, F.K.; Moreira, S.M.; Domingues, L.; Gama, F.M. Improving the Affinity of Fibroblasts for Bacterial Cellulose Using Carbohydrate-Binding Modules Fused to RGD. J. Biomed. Mater. Res. A 2010, 92, 9-17. [CrossRef]

213. Andrade, F.K.; Costa, R.; Domingues, L.; Soares, R.; Gama, M. Improving Bacterial Cellulose for Blood Vessel Replacement: Functionalization with a Chimeric Protein Containing a Cellulose-Binding Module and an Adhesion Peptide. Acta Biomater. 2010, 6, 4034-4041. [CrossRef]

214. Andrade, F.K.; Silva, J.P.; Carvalho, M.; Castanheira, E.M.; Soares, R.; Gama, M. Studies on the Hemocompatibility of Bacterial Cellulose. J. Biomed. Mater. Res. A 2011, 98, 554-566. [CrossRef]

215. Pértile, R.; Moreira, S.; Andrade, F.; Domingues, L.; Gama, M. Bacterial Cellulose Modified Using Recombinant Proteins to Improve Neuronal and Mesenchymal Cell Adhesion. Biotechnol. Prog. 2012, 28, 526-532. [CrossRef]

216. Abouhmad, A.; Mamo, G.; Dishisha, T.; Amin, M.; Hatti-Kaul, R. T4 Lysozyme Fused with Cellulose Binding Module for Antimicrobial Cellulosic Wound Dressing Materials. J. Appl. Microbiol. 2016, 121. [CrossRef]

217. Weishaupt, R.; Zünd, J.N.; Heuberger, L.; Zuber, F.; Faccio, G.; Robotti, F.; Ferrari, A.; Fortunato, G.; Ren, Q.; Maniura-Weber, K.; et al. Antibacterial, Cytocompatible, Sustainably Sourced: Cellulose Membranes with Bifunctional Peptides for Advanced Wound Dressings. Adv. Healthc. Mater. 2020, 9, 1901850. [CrossRef]

218. Raza, Z.A.; Riaz, S.; Banat, I.M. Polyhydroxyalkanoates: Properties and Chemical Modification Approaches for Their Functionalization. Biotechnol. Prog. 2018, 34, 29-41. [CrossRef]

219. Li, Z.; Yang, J.; Loh, X.J. Polyhydroxyalkanoates: Opening Doors for a Sustainable Future. NPG Asia Mater. 2016,8 , e265. [CrossRef]

220. López Durán, V.; Larsson, P.A.; Wågberg, L. Chemical Modification of Cellulose-Rich Fibres to Clarify the Influence of the Chemical Structure on the Physical and Mechanical Properties of Cellulose Fibres and Thereof Made Sheets. Carbohydr. Polym. 2018, 182, 1-7. [CrossRef]

221. Ramachandran, H.; Kannusamy, S. Blends of Polyhydroxyalkanoates (PHAs). In Polyhydroxyalkanoate (PHA) Based Blends, Composites and Nanocomposites; Royal Society of Chemistry: London, UK, 2015; ISBN 9781782622314.

222. Tavakolian, M.; Jafari, S.M.; van de Ven, T.G.M. A Review on Surface-Functionalized Cellulosic Nanostructures as Biocompatible Antibacterial Materials. Nano-Micro Lett. 2020, 12, 73. [CrossRef] 
223. Reddy, N.; Reddy, R.; Jiang, Q. Crosslinking Biopolymers for Biomedical Applications. Trends Biotechnol. $2015,33,362-369$. [CrossRef]

224. Bach, Q.-V.; Manh Vu, C. Bacterial Cellulose Filled Epoxy Resin-Based Green Composites: Fabrication and Characterization. Compos. Interfaces 2019, 1-18. [CrossRef]

225. Zhang, B.; Zhang, Y.; Luo, Z.; Han, W.; Qiu, W.; Zhao, T. Hierarchically Porous Zirconia Monolith Fabricated from Bacterial Cellulose and Preceramic Polymer. ACS Omega 2018, 3, 4688-4694. [CrossRef]

226. Sudhakar, Y.N.; Selvakumar, M.; Bhat, D.K. Methods of Preparation of Biopolymer Electrolytes. Biopolym. Electrolytes 2018, 35-52. [CrossRef]

227. Zhao, K.; Yang, X.; Chen, G.Q.; Chen, J.C. Effect of Lipase Treatment on the Biocompatibility of Microbial Polyhydroxyalkanoates. J. Mater. Sci. Mater. Med. 2002, 13, 849-854. [CrossRef] [PubMed]

228. Kai, Z.; Ying, D.; Guo-Qiang, C. Effects of Surface Morphology on the Biocompatibility of Polyhydroxyalkanoates. Biochem. Eng. J. 2003, 16, 115-123. [CrossRef]

229. Basnett, P.; Ching, K.Y.; Stolz, M.; Knowles, J.C.; Boccaccini, A.R.; Smith, C.; Locke, I.C.; Keshavarz, T.; Roy, I. Novel Poly(3Hydroxyoctanoate)/Poly(3-Hydroxybutyrate) Blends for Medical Applications. React. Funct. Polym. 2013, 73, 1340-1348. [CrossRef]

230. Mousavioun, P.; Halley, P.J.; Doherty, W.O.S. Thermophysical Properties and Rheology of PHB/Lignin Blends. Ind. Crop. Prod. 2013, 50, 270-275. [CrossRef]

231. Gerard, T.; Budtova, T. Morphology and Molten-State Rheology of Polylactide and Polyhydroxyalkanoate Blends. Eur. Polym. J. 2012, 48, 1110-1117. [CrossRef]

232. Takagi, Y.; Yasuda, R.; Yamaoka, M.; Yamane, T. Morphologies and Mechanical Properties of Polylactide Blends with Medium Chain Length Poly(3-Hydroxyalkanoate) and Chemically Modified Poly(3-Hydroxyalkanoate). J. Appl. Polym. Sci. 2004, 93, 2363-2369. [CrossRef]

233. Lim, J.; Chong, M.S.K.; Teo, E.Y.; Chen, G.Q.; Chan, J.K.Y.; Teoh, S.H. Biocompatibility Studies and Characterization of Poly(3Hydroxybutyrate-Co-3-Hydroxyhexanoate)/Polycaprolactone Blends. J. Biomed. Mater. Res. Part B Appl. Biomater. 2013, 101 B, 752-761. [CrossRef]

234. Altun, E.; Aydogdu, M.O.; Koc, F.; Crabbe-Mann, M.; Brako, F.; Kaur-Matharu, R.; Ozen, G.; Kuruca, S.E.; Edirisinghe, U.; Gunduz, O.; et al. Novel Making of Bacterial Cellulose Blended Polymeric Fiber Bandages. Macromol. Mater. Eng. 2018, 303, 1700607. [CrossRef]

235. Rivero-Buceta, V.; Aguilar, M.R.; Hernández-Arriaga, A.M.; Blanco, F.G.; Rojas, A.; Tortajada, M.; Ramírez-Jiménez, R.A.; Vázquez-Lasa, B.; Prieto, A. Anti-Staphylococcal Hydrogels Based on Bacterial Cellulose and the Antimicrobial Biopolyester Poly(3-Hydroxy-Acetylthioalkanoate-Co-3-Hydroxyalkanoate). Int. J. Biol. Macromol. 2020, 162, 1869-1879. [CrossRef]

236. Hsieh, C.Y.; Tsai, S.P.; Wang, D.M.; Chang, Y.N.; Hsieh, H.J. Preparation of $\gamma$-PGA/Chitosan Composite Tissue Engineering Matrices. Biomaterials 2005, 26, 5617-5623. [CrossRef]

237. Hajiali, H.; Shahgasempour, S.; Naimi-Jamal, M.R.; Peirovi, H. Electrospun PGA/Gelatin Nanofibrous Scaffolds and Their Potential Application in Vascular Tissue Engineering. Int. J. Nanomed. 2011, 6, 2133-2141. [CrossRef]

238. Aghdam, R.M.; Najarian, S.; Shakhesi, S.; Khanlari, S.; Shaabani, K.; Sharifi, S. Investigating the Effect of PGA on Physical and Mechanical Properties of Electrospun PCL/PGA Blend Nanofibers. J. Appl. Polym. Sci. 2012, 124, 123-131. [CrossRef]

239. Le Fer, G.; Babinot, J.; Versace, D.L.; Langlois, V.; Renard, E. An Efficient Thiol-Ene Chemistry for the Preparation of Amphiphilic PHA-Based Graft Copolymers. Macromol. Rapid Commun. 2012, 33, 2041-2045. [CrossRef] [PubMed]

240. Ashby, R.D.; Foglia, T.A.; Solaiman, D.K.Y.; Liu, C.-K.; Nuñez, A.; Eggink, G. Viscoelastic Properties of Linseed Oil-Based Medium Chain Length Poly(Hydroxyalkanoate) Films: Effects of Epoxidation and Curing. Int. J. Biol. Macromol. 2000, $27,355-361$. [CrossRef]

241. Karahalilotlu, Z.; Ercan, B.; Taylor, E.N.; Chung, S.; Denkbas, E.B.; Webster, T.J. Antibacterial Nanostructured Polyhydroxybutyrate Membranes for Guided Bone Regeneration. J. Biomed. Nanotechnol. 2015, 11, 2253-2263. [CrossRef]

242. Torres, M.G.; Talavera, J.R.R.; Muñoz, S.V.; Pérez, M.G.; Castro, M.P.C.; Cortes, J.C.; Muñoz, R.A.E. Effects of Solvents on the Radiation Grafting Reaction of Vinyl Compounds on Poly (3-Hydroxybutyrate). Radiat. Phys. Chem. 2015, 108, 87-94. [CrossRef]

243. Ma, Y.M.; Wei, D.X.; Yao, H.; Wu, L.P.; Chen, G.Q. Synthesis, Characterization and Application of Thermoresponsive Polyhydroxyalkanoate-Graft-Poly(N-Isopropylacrylamide). Biomacromolecules 2016, 17, 2680-2690. [CrossRef]

244. Tajima, K.; Iwamoto, K.; Satoh, Y.; Sakai, R.; Satoh, T.; Dairi, T. Advanced Functionalization of Polyhydroxyalkanoate via the UV-Initiated Thiol-Ene Click Reaction. Appl. Microbiol. Biotechnol. 2016, 100, 4375-4383. [CrossRef] [PubMed]

245. Wang, Y.Y.; Lü, L.X.; Shi, J.C.; Wang, H.F.; Xiao, Z.D.; Huang, N.P. Introducing RGD Peptides on PHBV Films through PEGContaining Cross-Linkers to Improve the Biocompatibility. Biomacromolecules 2011, 12, 551-559. [CrossRef]

246. Chung, M.G.; Kim, H.W.; Kim, B.R.; Kim, Y.B.; Rhee, Y.H. Biocompatibility and Antimicrobial Activity of Poly(3Hydroxyoctanoate) Grafted with Vinylimidazole. Int. J. Biol. Macromol. 2012, 50, 310-316. [CrossRef]

247. Abdelwahab, M.A.; El-Barbary, A.A.; El-Said, K.S.; El Naggar, S.A.; ElKholy, H.M. Evaluation of Antibacterial and Anticancer Properties of Poly(3-Hydroxybutyrate) Functionalized with Different Amino Compounds. Int. J. Biol. Macromol. 2019, 122, 793-805. [CrossRef] [PubMed]

248. Hu, S.-G.; Jou, C.-H.; Yang, M.-C. Antibacterial and Biodegradable Properties of Polyhydroxyalkanoates Grafted with Chitosan and Chitooligosaccharides via Ozone Treatment. J. Appl. Polym. Sci. 2003, 88, 2797-2803. [CrossRef] 
249. Arslan, H.; Hazer, B.; Yoon, S.C. Grafting of Poly(3-Hydroxyalkanoate) and Linoleic Acid onto Chitosan. J. Appl. Polym. Sci. 2007, 103, 81-89. [CrossRef]

250. Švorčík, P.S.S.S.N.S.K.S.R.V. Cytocompatibility of Polyhydroxybutyrate Modified by Plasma Discharge. Society 2014, 54, 1231-1238. [CrossRef]

251. Wang, C.; Sauvageau, D.; Elias, A. Immobilization of Active Bacteriophages on Polyhydroxyalkanoate Surfaces. ACS Appl. Mater. Interfaces 2016, 8, 1128-1138. [CrossRef]

252. Fernandes, S.C.M.; Sadocco, P.; Alonso-Varona, A.; Palomares, T.; Eceiza, A.; Silvestre, A.J.D.; Mondragon, I.; Freire, C.S.R. Bioinspired Antimicrobial and Biocompatible Bacterial Cellulose Membranes Obtained by Surface Functionalization with Aminoalkyl Groups. ACS Appl. Mater. Interfaces 2013, 5, 3290-3297. [CrossRef]

253. Sun, B.; Wei, F.; Li, W.; Xu, X.; Zhang, H.; Liu, M.; Lin, J.; Ma, B.; Chen, C.; Sun, D. Macroporous Bacterial Cellulose Grafted by Oligopeptides Induces Biomimetic Mineralization via Interfacial Wettability. Colloids Surf. B Biointerfaces 2019, 183. [CrossRef]

254. Rouabhia, M.; Asselin, J.; Tazi, N.; Messaddeq, Y.; Levinson, D.; Zhang, Z. Production of Biocompatible and Antimicrobial Bacterial Cellulose Polymers Functionalized by RGDC Grafting Groups and Gentamicin. ACS Appl. Mater. Interfaces 2014, 6, 1439-1446. [CrossRef]

255. Ye, S.; Jiang, L.; Wu, J.; Su, C.; Huang, C.; Liu, X.; Shao, W. Flexible Amoxicillin-Grafted Bacterial Cellulose Sponges for Wound Dressing: In Vitro and in Vivo Evaluation. ACS Appl. Mater. Interfaces 2018, 10, 5862-5870. [CrossRef]

256. Chuah, C.; Wang, J.; Tavakoli, J.; Tang, Y. Novel Bacterial Cellulose-Poly (Acrylic Acid) Hybrid Hydrogels with Controllable Antimicrobial Ability as Dressings for Chronic Wounds. Polymers 2018, 10. [CrossRef] [PubMed]

257. Liu, X.; Wang, Y.; Cheng, Z.; Sheng, J.; Yang, R. Nano-Sized Fibrils Dispersed from Bacterial Cellulose Grafted with Chitosan. Carbohydr. Polym. 2019, 214, 311-316. [CrossRef] [PubMed]

258. Pertile, R.A.N.; Andrade, F.K.; Alves, C.; Gama, M. Surface Modification of Bacterial Cellulose by Nitrogen-Containing Plasma for Improved Interaction with Cells. Carbohydr. Polym. 2010, 82, 692-698. [CrossRef]

259. Kurniawan, H.; Lai, J.T.; Wang, M.J. Biofunctionalized Bacterial Cellulose Membranes by Cold Plasmas. Cellulose 2012, 19, 1975-1988. [CrossRef]

260. Zhang, K.; Wu, J.; Zhang, W.; Yan, S.; Ding, J.; Chen, X.; Cui, L.; Yin, J. In Situ Formation of Hydrophobic Clusters to Enhance Mechanical Performance of Biodegradable Poly(l-Glutamic Acid)/Poly( $\varepsilon$-Caprolactone) Hydrogel towards Meniscus Tissue Engineering. J. Mater. Chem. B 2018, 6, 7822-7833. [CrossRef]

261. Chung, S.; Gentilini, C.; Callanan, A.; Hedegaard, M.; Hassing, S.; Stevens, M.M. Responsive Poly ( $\gamma$-Glutamic Acid) Fibres for Biomedical Applications. J. Mater. Chem. B 2013, 1, 1397-1401. [CrossRef]

262. Michiya, M.; Ken-ichiro, H.; Mariko, H.; Tatsuo, K.; Mitsuru, A. Stably-Dispersed and Surface-Functional Bionanoparticles Prepared by Self-Assembling Amphipathic Polymers of Hydrophilic Poly( $\gamma$-Glutamic Acid) Bearing Hydrophobic Amino Acids. Chem. Lett. 2004, 33, 398-399. [CrossRef]

263. Clarke, D.E.; Pashuck, E.T.; Bertazzo, S.; Weaver, J.V.M.; Stevens, M.M. Self-Healing, Self-Assembled $\beta$-Sheet Peptide-Poly $(\gamma-$ Glutamic Acid) Hybrid Hydrogels. J. Am. Chem. Soc. 2017, 139, 7250-7255. [CrossRef]

264. Cacicedo, M.L.; Pacheco, G.; Islan, G.A.; Alvarez, V.A.; Barud, H.S.; Castro, G.R. International Journal of Biological Macromolecules Chitosan-Bacterial Cellulose Patch of Ciprofloxacin for Wound Dressing: Preparation and Characterization Studies. Int. J. Biol. Macromol. 2020, 147, 1136-1145. [CrossRef]

265. Wahid, F.; Hu, X.H.; Chu, L.Q.; Jia, S.R.; Xie, Y.Y.; Zhong, C. Development of Bacterial Cellulose/Chitosan Based SemiInterpenetrating Hydrogels with Improved Mechanical and Antibacterial Properties. Int. J. Biol. Macromol. 2019, $122,380-387$. [CrossRef]

266. Fürsatz, M.; Skog, M.; Sivlér, P.; Palm, E.; Aronsson, C.; Skallberg, A.; Greczynski, G.; Khalaf, H.; Bengtsson, T.; Aili, D. Functionalization of Bacterial Cellulose Wound Dressings with the Antimicrobial Peptide $\epsilon$-Poly-L-Lysine. Biomed. Mater. Bristol 2018, 13. [CrossRef]

267. Levine, A.C.; Sparano, A.; Twigg, F.F.; Numata, K.; Nomura, C.T. Influence of Cross-Linking on the Physical Properties and Cytotoxicity of Polyhydroxyalkanoate (PHA) Scaffolds for Tissue Engineering. ACS Biomater. Sci. Eng. 2015, 1, 567-576. [CrossRef]

268. Zhang, X.; Li, Z.; Che, X.; Yu, L.; Jia, W.; Shen, R.; Chen, J.; Ma, Y.; Chen, G.Q. Synthesis and Characterization of Polyhydroxyalkanoate Organo/Hydrogels. Biomacromolecules 2019, 20, 3303-3312. [CrossRef]

269. Park, S.J.; Uyama, H.; Kwak, M.S.; Sung, M.H. Comparison of the Stability of Poly- $\gamma$-Glutamate Hydrogels Prepared by UV and $\gamma$-Ray Irradiation. J. Microbiol. Biotechnol. 2019, 29, 1078-1082. [CrossRef]

270. Meftahi, A.; Khajavi, R.; Rashidi, A.; Rahimi, M.K.; Bahador, A. Preventing the Collapse of 3D Bacterial Cellulose Network via Citric Acid. J. Nanostruct. Chem. 2018, 8, 311-320. [CrossRef]

271. Wang, C.; Wang, H.; Zou, F.; Chen, S.; Wang, Y. Development of Polyhydroxyalkanoate-Based Polyurethane Withwater-Thermal Response Shape-Memory Behavior as New 3D Elastomers Scaffolds. Polymers 2019, 11, 1927. [CrossRef]

272. Bakó, J.; Kerényi, F.; Hrubi, E.; Varga, I.; Daróczi, L.; Dienes, B.; Csernoch, L.; Gáll, J.; Hegedus, C. Poly- $\gamma$-Glutamic Acid Nanoparticles Based Visible Light-Curable Hydrogel for Biomedical Application. J. Nanomater. 2016, 2016. [CrossRef] 
273. Schmutz, M.; Borges, O.; Jesus, S.; Borchard, G.; Perale, G.; Zinn, M.; Sips, Ä.A.J.A.M.; Soeteman-Hernandez, L.G.; Wick, P.; Som, C. A Methodological Safe-by-Design Approach for the Development of Nanomedicines. Front. Bioeng. Biotechnol. 2020, 8, 258. [CrossRef]

274. Som, C.; Schmutz, M.; Borges, O.; Jesus, S.; Borchard, G.; Nguyen, V.; Perale, G.; Casalini, T.; Zinn, M.; Amstutz, V.; et al. Guidelines for Implementing a Safe-by-Design Approach for Medicinal Polymeric Nanocarriers; Empa: St. Gallen, Switzerland, 2019. 